Review

\title{
Metal Complexes Containing Natural and Artificial Radioactive Elements and Their Applications
}

\section{Oxana V. Kharissova ${ }^{1}$, Miguel A. Méndez-Rojas ${ }^{2}$, Boris I. Kharisov ${ }^{1{ }^{*} *}$, Ubaldo Ortiz Méndez ${ }^{1}$ and Perla Elizondo Martínez ${ }^{1}$}

1 Facultad de Ciencias Químicas, Universidad Autónoma de Nuevo León, Ciudad Universitaria, Monterrey, N.L. C.P. 66450, Mexico

2 Departamento de Ciencias Químico-Biológicas, Universidad de las Américas Puebla, Sta. Catarina Mártir, Cholula, Puebla. C.P. 72810, Mexico

* Author to whom correspondence should be addressed; E-Mail: bkhariss@hotmail.com; Tel.: +52-818-220-4900; Fax: +52-818-220-4918.

Received: 7 June 2014; in revised form: 9 July 2014 / Accepted: 11 July 2014 /

Published: 24 July 2014

\begin{abstract}
Recent advances (during the 2007-2014 period) in the coordination and organometallic chemistry of compounds containing natural and artificially prepared radionuclides (actinides and technetium), are reviewed. Radioactive isotopes of naturally stable elements are not included for discussion in this work. Actinide and technetium complexes with $\mathrm{O}-$, N-, N,O, N,S-, P-containing ligands, as well $\pi$-organometallics are discussed from the view point of their synthesis, properties, and main applications. On the basis of their properties, several mono-, bi-, tri-, tetra- or polydentate ligands have been designed for specific recognition of some particular radionuclides, and can be used in the processes of nuclear waste remediation, i.e., recycling of nuclear fuel and the separation of actinides and fission products from waste solutions or for analytical determination of actinides in solutions; actinide metal complexes are also usefulas catalysts forcoupling gaseous carbon monoxide, as well as antimicrobial and anti-fungi agents due to their biological activity. Radioactive labeling based on the short-lived metastable nuclide technetium-99m $\left({ }^{99 m} \mathrm{Tc}\right)$ for biomedical use as heart, lung, kidney, bone, brain, liver or cancer imaging agents is also discussed. Finally, the promising applications of technetium labeling of nanomaterials, with potential applications as drug transport and delivery vehicles, radiotherapeutic agents or radiotracers for monitoring metabolic pathways, are also described.
\end{abstract}


Keywords: metal complex; coordination bond; organometallics; radionuclide; labeling; technetium; actinides

\section{Introduction}

The actinide elements have unique physical and chemical properties related to their low-lying $7 p$, $6 d$, and $5 f$ orbitals. Their more common oxidation state is +3 , with general electronic configurations $7 p$ $6 d 5 f^{\mathrm{n}}$ (where $\mathrm{n}=0,1,2 \ldots, 14$ ). According to this definition, actinium, element 89 , is the first member of the actinide series of elements, although it has no $5 f$ electrons in its metallic, gaseous, or ionic forms [1]. Technetium (element 43) possesses two radioactive isotopes with long half-lives: ${ }^{99} \mathrm{Tc}$ $\left(2.12 \times 10^{5}\right.$ years, has practical use $)$ and ${ }^{98} \mathrm{Tc}\left(1.5 \times 10^{6}\right.$ years, it is a rhenium analogue $)$. Both, actinides and ${ }^{99} \mathrm{Tc}$, although able to form metal complexes with ligands containing $\mathrm{O}-, \mathrm{N}-, \mathrm{S}-$ or $\mathrm{P}$ - heterodonor atoms, have different coordination chemistry, which is largely due to the differences in size and electronic structure. However, given their radioactive nature and their common uses as radiotracers, fuels, catalysts or radiopharmaceuticals, it makes sense to review the recent literature on their particular preparation methods and physical and chemical characteristics.

Actinides and technetium have numerous applications, but their uses strongly depend on the individual properties of each element. In particular, ${ }^{225} \mathrm{Ac}$, which has a 10 -day half-life, is a potential agent for $\alpha$-particle therapy, as it decays emitting three such particles [2]. On the contrary, curium is an underexplored element for a variety of reasons. ${ }^{244} \mathrm{Cm}$ has a short half-life of 18 years and radiation damage in its compounds is very rapid. ${ }^{242} \mathrm{Cm}$ was also available, but is even shorter-lived with a half-life of 163 days. Actinide-containing nanocrystals are currently also an object of intensive investigations [3-6].

Among the natural and artificial radioactive elements (Tc, Pm, Po, Fr, Ra, Ac and actinides), coordination and organometallic compounds of only technetium and the actinide series (An) are well represented at the present time [7-10]. The interest on their metal complexes has been motivated by the extended use of Tc, available in kilogram amounts, for medical and technical purposes. Meanwhile, actinides are important on their own for the nuclear industry and extraction and analytical applications [11-13]. They are also used for isotope separation, as antibacterial materials, drug delivery and anticancer radiopharmaceuticals, for the creation of labeled biomolecules, and radiation-induced processes. In the present review, dedicated to the coordination and organometallic chemistry of the actinides and Tc, we intended to present the synthetic techniques for these compounds according with the ligand nature.

\section{Part A. Actinides Chemistry}

\section{A.1. General Concepts on Actinide Complexes}

The electronic states of actinide atoms and ions are significantly different from those of lanthanides. In both series the successive filling of the $f$ level proceeds up to the $f^{14}$ configuration, but in the actinide series the filling only formally starts with Th, which has no $f$ electrons and is the electronic 
analog of Hf. In contrast to lanthanides, the actinides display a wide collection of oxidation states. As $\mathrm{An}^{3+}$ ions they are analogs of the related $\mathrm{Ln}^{3+}$ ions, but as $\mathrm{An}^{4+}$ they resemble both $\mathrm{Hf}(\mathrm{IV})$ and $\mathrm{Ce}(\mathrm{IV})$ compounds. Actinides form various $\mathrm{An}^{\mathrm{m}+}(\mathrm{m}=2-4)$ and $\mathrm{AnO}_{2}{ }^{\mathrm{m}+}(\mathrm{m}=1,2)$ ions containing only $f$ electrons. The shielding by $f$ electrons causes the contraction of the $\mathrm{An}^{3+}$ ions and the magnitude of the actinide contraction along the series to be parallel to that of the lanthanide contraction. Differences in correlation between the energy of $5 f$ and $6 d$, as well as the $4 f$ and $5 d$, levels lead to noticeable differences in the magnetic properties and electronic spectra of $\mathrm{Ln}^{\mathrm{m}+}$ and $\mathrm{An}^{\mathrm{m}+}$ ions. Technetium $\left(4 s^{2} 4 p^{6} 4 d^{5} 5 s^{2}\right.$ or $\left.4 s^{2} 4 p^{6} 4 d^{6} 5 s^{1}\right)$ has oxidation states from +1 to +7 , however, those from +4 to +7 are the most stable.

Spin-orbit coupling $(J)$ for the $\mathrm{An}^{3+}$ ions is very strong $\left(2,000-4,000 \mathrm{~cm}^{-1}\right)$ and larger that those for the $\mathrm{Ln}^{3+}$ ions $\left(\mathrm{ca} .1,000 \mathrm{~cm}^{-1}\right)$. In contrast to lanthanides, $J$ is comparable with the ligand-field splitting and is no longer a good quantum number. The proximity of the energy of the $5 f$ and $6 d$ orbitals and the population of thermally accessible excited levels lead to the expression for effective magnetic moment $\mu_{\mathrm{e}}=\mathrm{g}[\mathrm{J}(\mathrm{J}+1)]^{1 / 2}$ being appropriate for the lanthanides, but not for actinides.

Actinide organometallic complexes are compounds containing an actinide-carbon $\pi$-bond, an actinide-carbon $\sigma$-bond, or a combination of both. Actinide organometallic complexes are known for all of the early actinide elements (An) from thorium through californium. However, the majority of the reported data is on Th and $\mathrm{U}$ organometallic chemistry due to the extremely long half-lives of commercially available ${ }^{232} \mathrm{Th}$ (in the form of $\left.\mathrm{ThCl}_{4}\right)$ and ${ }^{238} \mathrm{U}\left(\right.$ as $\left.\mathrm{UCl}_{4}\right)\left(1.41 \times 10^{10}\right.$ and $4.468 \times 10^{9}$ years, respectively). Actinides have large metal and ionic radii and, therefore, large coordination numbers $(C N)$ of up to 15 . The uranium $6 d$ orbitals play the primary role in covalent bonding between the metal and the ligand, while the $5 f$ orbitals have a secondary role.

In contrast to lanthanides, the actinides have a variety of oxidation states in aqueous solution. The stable oxidation states go from +3 for Ac to +6 for $U$ and $\mathrm{Np}$ and then successively decrease to +3 for Am and succeeding elements except $\mathrm{No}(+2)$. The maximum and stable oxidation states coincide for Ac, Th, $\mathrm{Pa}, \mathrm{U}, \mathrm{Md}$, and Lr. Stable states are +7 for $\mathrm{Np}$ and $\mathrm{Pu},+6$ for $\mathrm{Am},+4$ for $\mathrm{Cm}, \mathrm{Bk}, \mathrm{Cf}$, Es, and Fm, and +3 for No. The unstable (except for No and Md) oxidation state +2 is known for nearly all actinides in aqueous solution. The $\mathrm{An}^{2+}, \mathrm{An}^{3+}, \mathrm{An}^{4+}, \mathrm{AnO}^{2+}$, and $\mathrm{AnO}_{2}{ }^{2+}$ hydrated ions are known, which act as Brönsted acids. The $\mathrm{An}^{4+}$ cations are characteristic for actinides from Th through $\mathrm{Cf}\left(\mathrm{U}^{4+}\right.$ is readily oxidized) and in the case of Th is the only one existing in solution. Their acidity decreases in the order $\mathrm{Pa}^{4+}>>\mathrm{U}^{4+}>\mathrm{Pu}^{4+}>\mathrm{Np}^{4+}>\mathrm{Th}^{4+}$. The monoatomic ions exist only in very dilute solutions and tend to form polynuclear species when the concentration is increased. The acidity of the $\mathrm{An}^{\mathrm{n}+}$ ions depends on the charge and radius of the central atom, so the $\mathrm{An}^{4+}$ and $\mathrm{AnO}_{2}{ }^{2+}$ ions are much stronger acids than $\mathrm{An}^{3+}$ and $\mathrm{AnO}_{2}{ }^{+}$, respectively. The redox behavior of the actinides is complicated by their high radioactivity, leading, in particular, to formation of $\mathrm{H}_{2} \mathrm{O}_{2}$ in aqueous solutions.

Moessbauer spectroscopy is a very useful tool to deduce the oxidation state and symmetry of the ligand environment. The gamma-resonance effect is observed for ${ }^{232} \mathrm{Th},{ }^{231} \mathrm{~Pa},{ }^{238} \mathrm{U},{ }^{240} \mathrm{Pu},{ }^{243} \mathrm{Am}$, and especially for ${ }^{237} \mathrm{~Np}$ with a ${ }^{237} \mathrm{U}$ source. The isomer shifts for $\mathrm{Np}$ (VII) compounds are the largest (up to $-70 \mathrm{~mm} / \mathrm{s}$ ) and decrease to $+30 \mathrm{~mm} / \mathrm{s}$ for $\mathrm{Np}$ (III). 


\section{A.2. Actinide Complexes with O-Containing Ligands}

Although actinide metal complexes with the simplest inorganic ligands like water and anions were well studied in the previous century, sometimes novel and fresh ideas and calculation results on their structures and properties appear in the available literature. Thus, Car-Parrinello molecular dynamics simulations were used to examine the hydration structures, coordination energetics, and the first hydrolysis constants of $\mathrm{Pu}^{3+}, \mathrm{Pu}^{4+}, \mathrm{PuO}_{2}{ }^{+}$, and $\mathrm{PuO}_{2}{ }^{2+}$ ions were determined in aqueous solution at $300 \mathrm{~K}$. It was found that the hexavalent $\mathrm{PuO}_{2}{ }^{2+}$ species are coordinated to five aquo ligands while the pentavalent $\mathrm{PuO}_{2}{ }^{+}$complex is coordinated to four aquo ligands. The $\mathrm{Pu}^{3+}$ and $\mathrm{Pu}^{4+}$ ions are both coordinated to eight water molecules. The first hydrolysis constants obtained for $\mathrm{Pu}^{3+}$ and $\mathrm{PuO}_{2}{ }^{2+}$ are 6.65 and 5.70, respectively, all within $0.3 \mathrm{pH}$ unit of the experimental values (6.90 and 5.50, respectively) [14]. Among other simple ligands, carbonates and borates have been also studied. Thus, curium(III) is able to form a stable complex in a high ionic strength aqueous solution, in the temperature range of $10-70{ }^{\circ} \mathrm{C}$, as demonstrated recently by a time-resolved laser-induced fluorescence spectroscopy study [15]. Borate complex $\mathrm{Cm}_{2}\left[\mathrm{~B}_{14} \mathrm{O}_{20}(\mathrm{OH})_{7}\left(\mathrm{H}_{2} \mathrm{O}\right)_{2} \mathrm{Cl}\right]$ was synthesized [16] in autoclave using ${ }^{248} \mathrm{CmCl}_{3}(3 \%$ ${ }^{246} \mathrm{Cm}$ ) and boric acid as the starting materials. Its crystallographic (Figure 1) and spectroscopic studies provided complementary information about this complex $\mathrm{Cm}^{\mathrm{III}}$ borate. Both confirmed two distinct sites that are averaged in the crystal structure. It was hypothized that actinide borate compounds yield very distinct chemistry among $5 f$ elements because of the large polarizability of the $\mathrm{BO}_{3}$ units. This yields unusual bonding with $5 f$ orbitals that is absent in most other ligand systems.

Figure 1. Views of two different coordination environments of $\mathrm{Cm}^{\text {III }}$ sites in $\mathrm{Cm}_{2}\left[\mathrm{~B}_{14} \mathrm{O}_{20}(\mathrm{OH})_{7}\left(\mathrm{H}_{2} \mathrm{O}\right)_{2} \mathrm{Cl}\right]$ with resolved disorder. (a) Nine-coordinated $\mathrm{Cm}(\mathrm{III})$ complex; (b) Ten-coordinated Cm(III) complex.
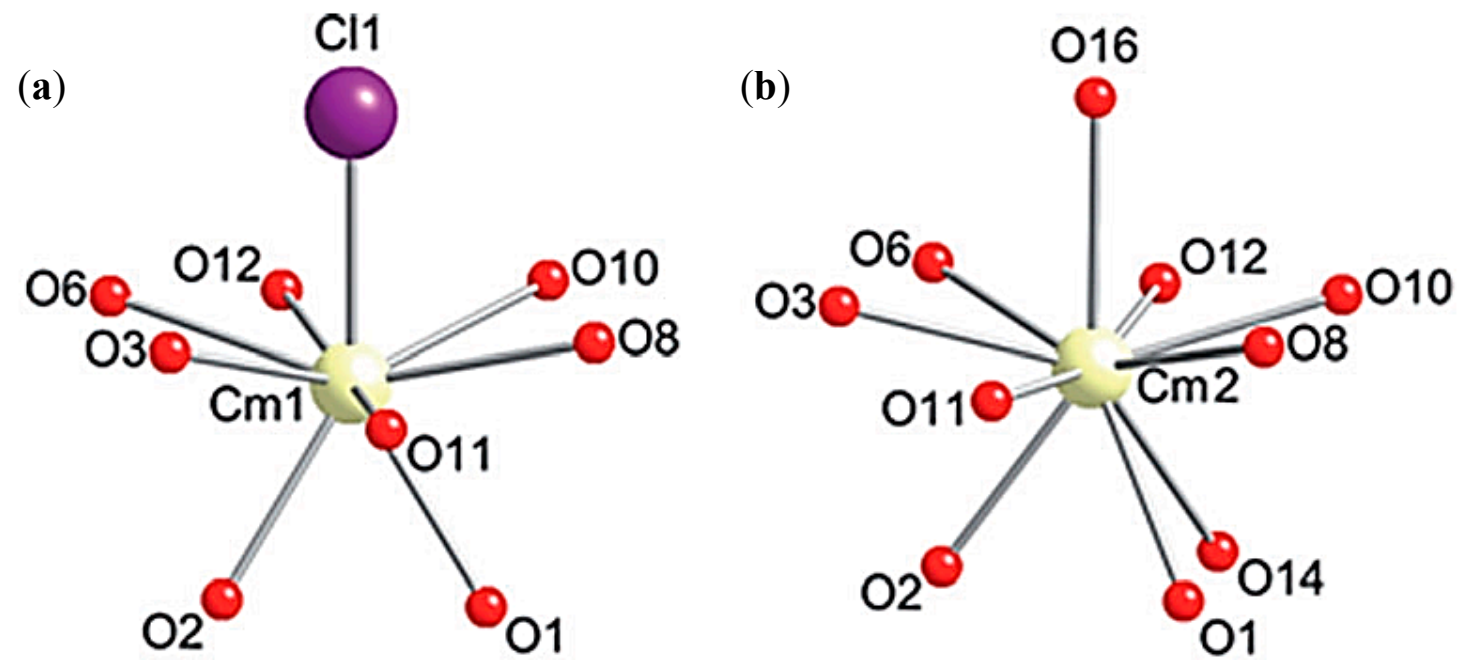

Organic ligands are obviously represented by a major number of examples. Thus, the structure of the dimethyl sulfoxide (DMSO)-solvated thorium(IV) ions was studied in solution by EXAFS) and the structure of the solid oxonium bis[nonakis( $\kappa O$-dimethyl sulfoxide)] thorium(IV) trifluoromethane-sulfonate dihydrate, $\left(\mathrm{H}_{3} \mathrm{O}\right)\left[\mathrm{Th}\left(\left(\mathrm{CH}_{3}\right)_{2} \mathrm{SO}\right)_{9}\right]_{2}\left(\mathrm{CF}_{3} \mathrm{SO}_{3}\right)_{9} \cdot 2 \mathrm{H}_{2} \mathrm{O}$ was determined [17]. It consists of two individual nonakis( $\kappa-O$-dimethyl sulfoxide)thorium(IV) units, both of which have a tricapped trigonal prismatic configuration, as also found earlier in nonakis(dimethyl sulfoxide)thorium(IV) perchlorate. The 
DMSO-solvated thorium(IV) ion is nine-coordinate in both solution and the solid state with average Th-O bond lengths of $2.45 \AA$. On the contrary, the dmso-solvated lanthanoid(III) ions are eight-coordinate.

Actinide carboxylates have been extremely widely studied. Thus, the results on the optical absorption and symmetry of the $\mathrm{Np}(\mathrm{V})$ complexes with dicarboxylate and diamide ligands (Figure 2) are reviewed [18]. It was demonstrated that the optical absorption properties of the $\mathrm{Np}(\mathrm{V})$ complexes are governed by their symmetry. The presence of carboxylates could lead to changes in the forms of actinide ions in solution. For example, hydrated actinide(IV) ions undergo hydrolysis and further polymerization and precipitation with increasing $\mathrm{pH}$ [19]. The resulting amorphous and partly crystalline oxydydroxides $\mathrm{AnO}_{n}(\mathrm{OH})_{4-2 n} \cdot x \mathrm{H}_{2} \mathrm{O}$ can usually be observed as colloids above the $\mathrm{An}(\mathrm{IV})$ solubility limit. The aging process of such colloids results in crystalline $\mathrm{AnO}_{2}$. The colloids can be avoided in the presence of carboxylates, forming polynuclear complexes in the solution, in a competition in between complexation and hydrolysis. Most of these polynuclear complexes poses a hexanuclear core with general formula $\left[\mathrm{An}_{6}\left(\mu_{3}-\mathrm{O}\right)_{4}\left(\mu_{3}-\mathrm{OH}\right)_{4}\right]^{12+}$ terminated by 12 carboxylate ligands. The An(IV) carboxylates show An-An distances which are $\sim 0.03 \AA$ shorter than the An-An distances in $\mathrm{AnO}_{2}$ like colloids. In addition, the complexation of $\mathrm{Eu}(\mathrm{III}), \mathrm{Am}(\mathrm{III})$ and $\mathrm{Cm}(\mathrm{III})$ with dicarboxylate anions with $\mathrm{O}, \mathrm{N}$ or $\mathrm{S}$ donor groups was measured in $I=6.60 \mathrm{~mol} / \mathrm{kg}\left(\mathrm{NaClO}_{4}\right)$ at temperatures of $0-60{ }^{\circ} \mathrm{C}$ by potentiometry and solvent extraction [20]. It was shown that, despite their endothermic complexation enthalpies, these complexes are stable due to their high complexation entropies. The formation of 1:1:1 ternary complexes of M(EDTA)with the dicarboxylate moiety may favors the formation of several coordination environments of these ternary complex, behaving as bidentate or monodentate coordination modes, depending of the chain length in between both carboxylate coordinating groups (1, for malonate to 4 for adipate).

Figure 2. Oxydiamide and dicarboxylic acid ligands: (a) oxalic acid (ox), (b) oxydiacetic acid (ODA), (c) iminodiacetic acid (IDA), (d) dipicolinic acid (DPA), (e) Nmethyliminodiacetic acid (MIDA), (f) $N, N, N^{\prime}, N^{\prime}$-tetramethyl-3-oxa-glutaramide (TMOGA).

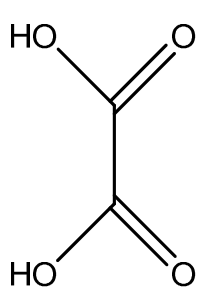

a

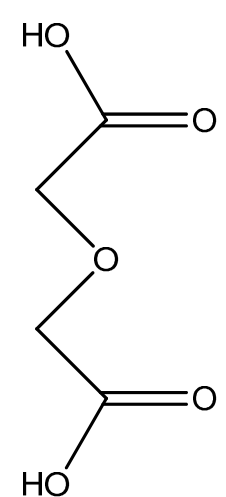

b

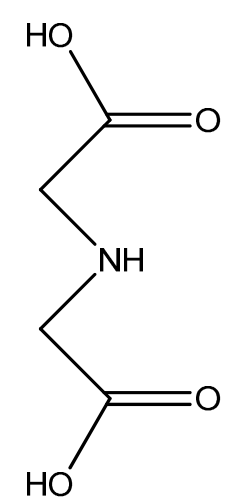

c

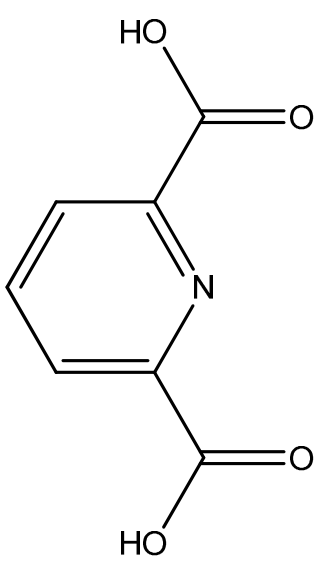

d

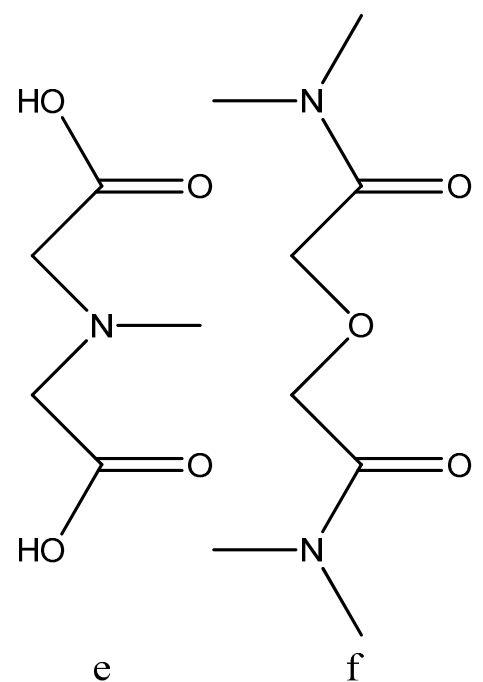

e 
Among particulate carboxylates, uranyl complexes (Figure 3) with phenylalanine and the analogous ligand phenylpropionate were investigated in aqueous solution by attenuated total reflection (ATR) Fourier transform infrared (FT-IR) spectroscopy [21].

Figure 3. Chemical structures of the ionic forms of L-phenylalanine and of the proposed uranyl(VI) complex.

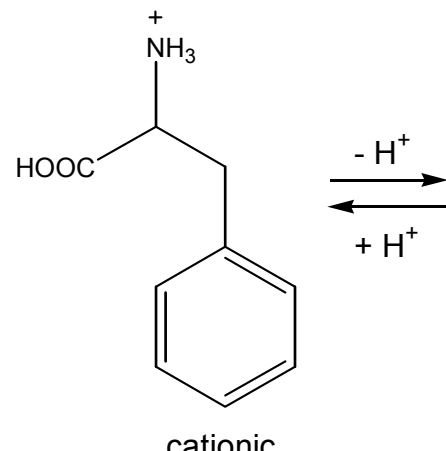

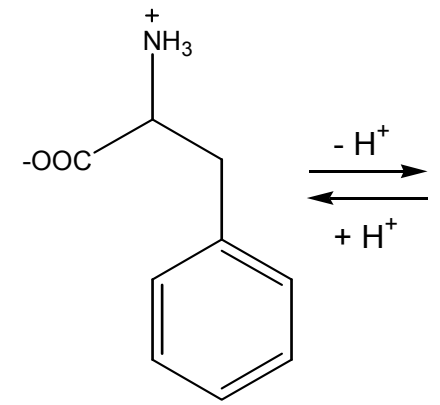

zwitterionic<smiles>NC(Cc1ccccc1)C(=O)[O-]</smiles>

anionic

L-phenylalanine

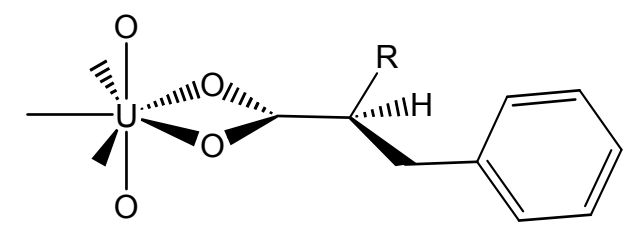

$\mathrm{R}=\mathrm{H}$; Uranyl phenylpropionate

$\mathrm{R}=\mathrm{NH}_{3}{ }^{+}$; Uranyl phenylalanine

A bidentate binding of the carboxylate group to the actinide ion was observed by the characteristic shifts of the carboxylate modes. The carboxylate functional group was found to be predominant for the binding of the heavy metal ion.Complexes with other organic acids are also common. Thus, the complexation of protactinium $(\mathrm{V})$ by oxalate was studied by a series of methods, indicating the formation of a highly charged anionic complex. The formation constants of $\mathrm{PaO}\left(\mathrm{C}_{2} \mathrm{O}_{4}\right)^{+}, \mathrm{PaO}\left(\mathrm{C}_{2} \mathrm{O}_{4}\right)_{2}{ }^{-}$, and $\mathrm{PaO}\left(\mathrm{C}_{2} \mathrm{O}_{4}\right)_{3}{ }^{3-}$ were determined from solvent extraction data by using protactinium at tracer scale $\left(C_{\mathrm{Pa}}<10^{-10} \mathrm{M}\right)$. Complexation reactions of $\mathrm{Pa}(\mathrm{V})$ with oxalate were found to be exothermic with relatively high positive entropic variation [22]. The complexation of americium(III) with salicylic acid (Figure 4a) was studied [23] at trace metal concentrations using a $2.0 \mathrm{~m}$ long path flow cell for UV-Vis spectroscopy.

Figure 4. (a) Salicylic acid; (b) citrate anion, (c) nitrilotriacetic acid.<smiles>O=C(O)c1ccccc1O</smiles>

(a)<smiles>O=C(O)CC(O)(CC(=O)O)C(=O)O</smiles>

(b)

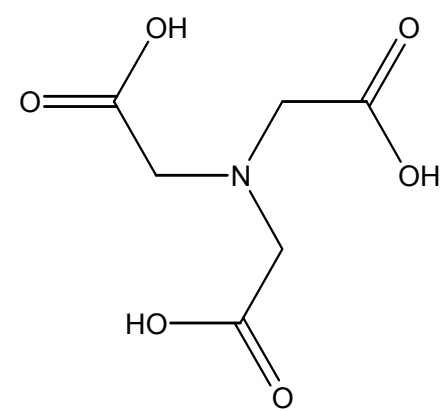

(c) 
Americium(III) has a very low threshold detection limit of $5 \times 10^{-9} \mathrm{M}$ in water at $\mathrm{pH} 3.0$. It was found that at $\mathrm{pH} 5.0$ in an aqueous $0.1 \mathrm{M} \mathrm{NaClO}_{4}$ solution, two novel Am(III)-salycylate complexes were formed, as indicated by a red shift of its characteristic absorption band $\left(\lambda_{\max }\right)$ in the UV-Visible spectra. We would like to note that americium evolves in nuclear power plants and contributes to the activity of radioactive waste, so, it has to be considered in radioactive waste management.

Figure 5. (a) ORTEP representation of $\left[\mathrm{Co}\left(\mathrm{NH}_{3}\right)_{6}\right]\left[\mathrm{Am}(\mathrm{NTA})_{2}\left(\mathrm{H}_{2} \mathrm{O}\right)\right] \cdot 8 \mathrm{H}_{2} \mathrm{O}$. Thermal ellipsoids are drawn at the $50 \%$ probability level, $\mathrm{H}$ atoms omitted for clarity. Dashed lines indicate $\mathrm{H}$-bonding interactions; (b) coordination polyhedron of the Am atom showing distorted tricapped trignal prism.

(a)

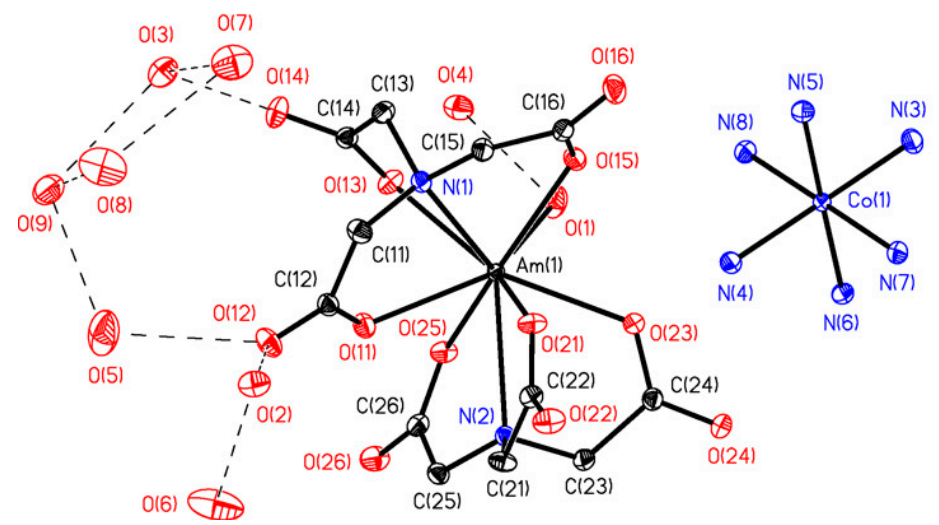

(b)

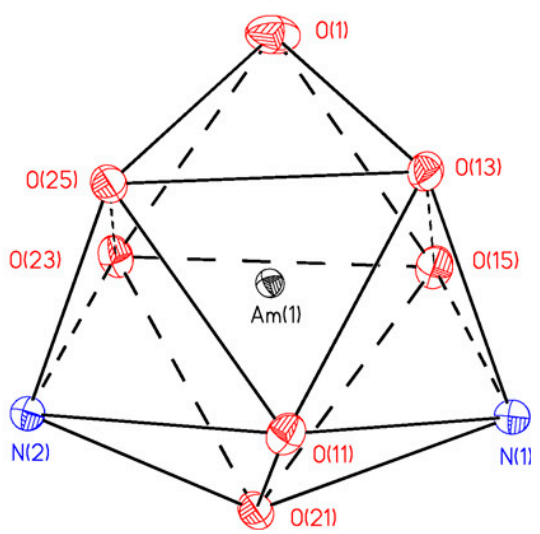

Figure 6. (a) ORTEP representation of $\left[\mathrm{Co}\left(\mathrm{NH}_{3}\right)_{6}\right]_{2} \mathrm{~K}\left[\mathrm{Am}_{3}(\mathrm{Cit})_{4}\left(\mathrm{H}_{2} \mathrm{O}\right)_{3}\right] \cdot 18 \mathrm{H}_{2} \mathrm{O}$. Thermal ellipsoids are drawn at the $50 \%$ probability level, $\mathrm{H}$ atoms and coordination water molecules omitted for clarity; (b) coordination polyhedra of Am atoms. Symmetry transformations: $\mathrm{A}-(1-\mathrm{x}, \mathrm{y}, 0.5-\mathrm{z})$; $\mathrm{B}-(1-\mathrm{x},-\mathrm{y}, 1-\mathrm{z}) ; \mathrm{C}-(-\mathrm{x}, \mathrm{y}, 0.5-\mathrm{z})$.

(a)
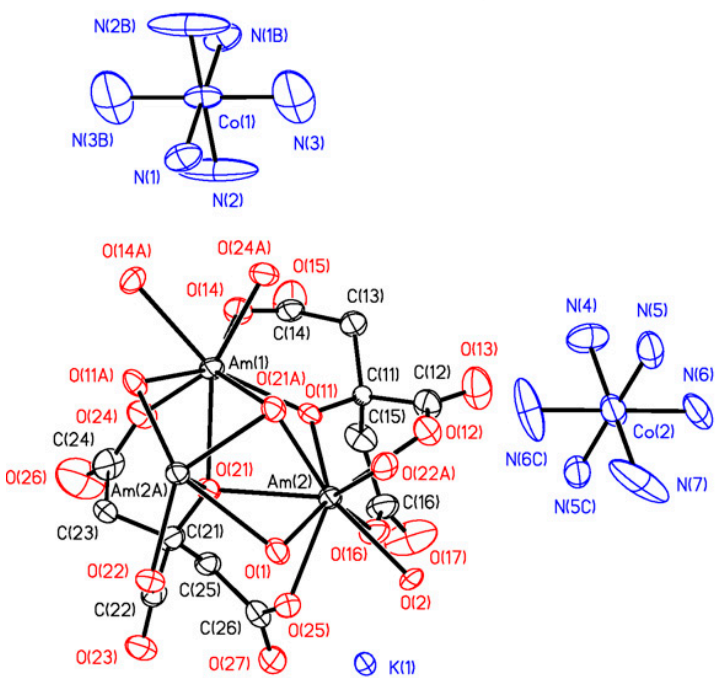

(b)

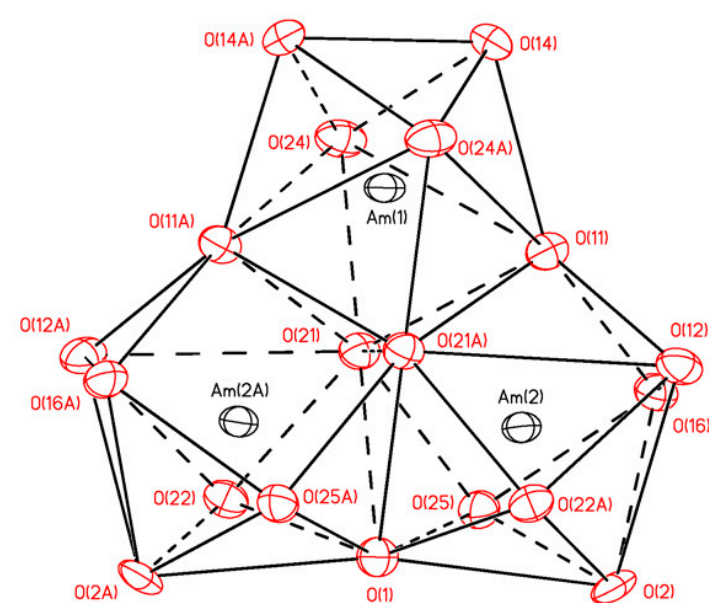

Only a few publications concerning the complexation of Am(III) with inorganic and organic ligands are available, especially for the complexation with humic substances [1] and chelating agents. The binary complexation of $\mathrm{Am}^{3+}, \mathrm{Cm}^{3+}$ and $\mathrm{Eu}^{3+}$ with citrate anion was studied at $\mathrm{I}=6.60 \mathrm{~m}\left(\mathrm{NaClO}_{4}\right)$ in the 
temperatures range of $0-60{ }^{\circ} \mathrm{C}$ employing a solvent extraction technique with di-(2-ethylhexyl)phosphoric $\mathrm{acid} /$ heptanes [24]. Two complexes, $\mathrm{MCit}$ and $\mathrm{MCit}_{2}$, were formed at all temperatures. Positive enthalpy and entropy values for the formation of both complexes were interpreted as due to the contributions from the dehydration of the metal ions exceeding the exothermic cation-anion pairing. In addition, two types of ligands that have in common three carboxylic groups, namely the citric acid (citric anion, see Figure 4b) and nitrilotriacetic acid, Figure 4c), and their americium complexes $\left[\mathrm{Co}\left(\mathrm{NH}_{3}\right)_{6}\right]\left[\mathrm{Am}(\mathrm{NTA})_{2}\left(\mathrm{H}_{2} \mathrm{O}\right)\right] \cdot 8 \mathrm{H}_{2} \mathrm{O}$ (Figure 5) and $\left[\mathrm{Co}\left(\mathrm{NH}_{3}\right)_{6}\right]_{2} \mathrm{~K}\left[\mathrm{Am}_{3}(\mathrm{Cit})_{4}\left(\mathrm{H}_{2} \mathrm{O}\right)_{3}\right] \cdot 18 \mathrm{H}_{2} \mathrm{O}$ (Figure 6) were discussed [25]. In all cases the americium complexes were found to be isostructural with their $\mathrm{Nd}$ equivalents.

\section{A.3. Actinide Complexes with N, N, O- and N,S-Containing Ligands}

\section{A.3.1. Complexes with N-Containing Ligands}

Actinide complexes with $\mathrm{N}$-containing ligands are represented by a variety of examples. Thus, the terminal uranium(V) nitride complex [UN(TrenTIPS)][Na(12-crown-4) $\left.)_{2}\right]$ in which TrenTIPS = $\left[\mathrm{N}\left(\mathrm{CH}_{2} \mathrm{CH}_{2} \mathrm{NSiPr}_{3}^{i}\right)_{3}\right]^{3-}$ and $\left.\operatorname{Pr}^{i}=\mathrm{CH}\left(\mathrm{CH}_{3}\right)_{2}\right\}$ (Scheme 1) was prepared by reaction of the uranium(III) complex [U(TrenTIPS)] with sodium azide followed by abstraction and encapsulation of the sodium cation by the polydentate crown ether 12-crown-4 [26].

Scheme 1. Reaction scheme for formation of [UN(TrenTIPS)][Na(12-crown-4) 2 .

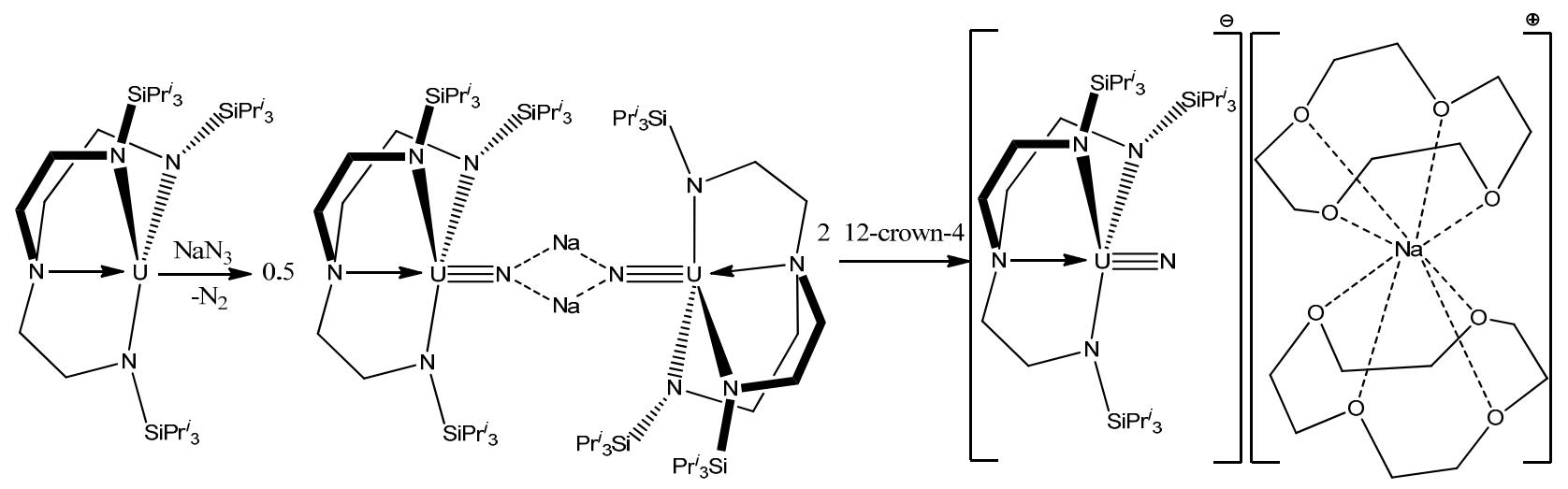

A uranium-terminal nitride bond length of $\sim 1.825 \AA$ was revealed. It should be noted that uranium nitride $[\mathrm{U} ; \mathrm{N}]_{x}$ compounds may become an interesting alternative nuclear power source, although there is not too much information about their potential use and properties. It was shown [27], that a terminal uranium nitride complex can be generated by photolysis of an azide precursor (Scheme 2). The transient $\mathrm{U}, \mathrm{N}$ fragment is reactive and undergoes insertion into a ligand $\mathrm{C}-\mathrm{H}$ bond to generate new $\mathrm{N}-\mathrm{H}$ and N-C bonds. A complex $\left[\mathrm{C}\left(\mathrm{NH}_{2}\right)_{3}\right]_{3}\left[\mathrm{NpO}_{2}\left(\mathrm{CrO}_{4}\right)_{2}\right]\left(\mathrm{H}_{2} \mathrm{O}\right)$ of $\mathrm{Np}(\mathrm{V})$ with the chromate ion and an organic outer-sphere guanidinium cation (Figure 7) was isolated from an aqueous solution [28]. Its structure is based on anionic chains $\left[\mathrm{CpO}_{2}\left(\mathrm{CrO}_{4}\right)_{2}\right]_{n}{ }^{3{ }^{-}}$(Figure 8) between which exist guanidinium cations and crystallization water molecules. Coordination polyhedra of the $\mathrm{Np}$ atoms (pentagonal bipyramids) in the anionic chains are joined in pairs through common equatorial edges. 
Scheme 2. Photolysis of azide complex (left) generates a transient terminal uranium nitride (right).

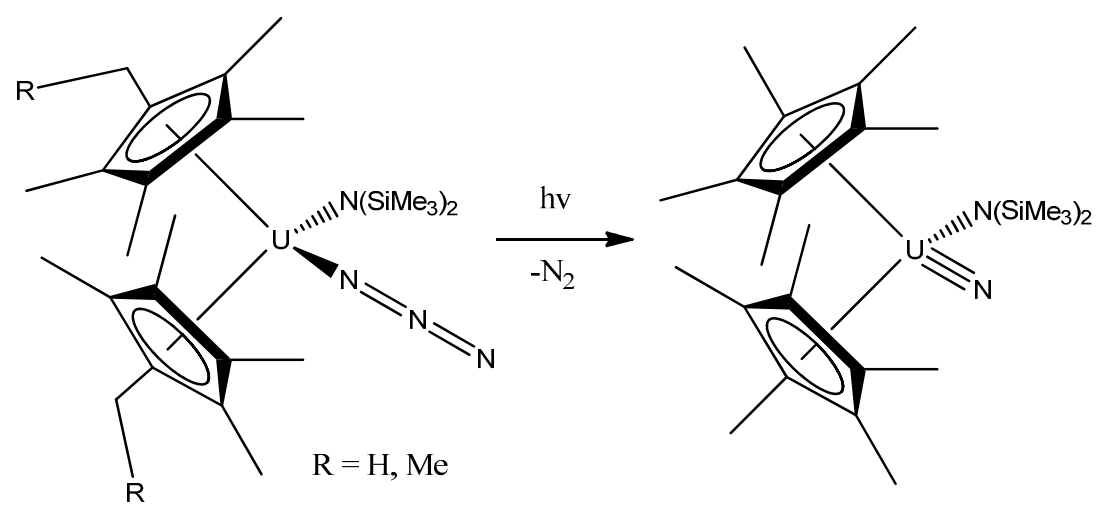

Figure 7. Guanidinium cation.

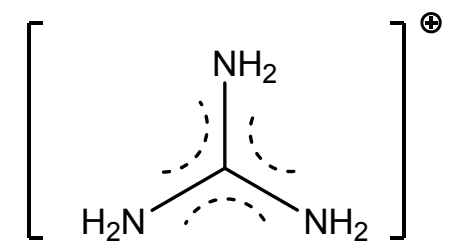

Figure 8. Anionic chain $\left[\mathrm{CpO}_{2}\left(\mathrm{CrO}_{4}\right)_{2}\right]_{n}{ }^{3 n^{-}}$in the structure of $\left[\mathrm{C}\left(\mathrm{NH}_{2}\right)_{3}\right]_{3}\left[\mathrm{NpO}_{2}\left(\mathrm{CrO}_{4}\right)_{2}\right]\left(\mathrm{H}_{2} \mathrm{O}\right)$. Thermal vibrational ellipsoids are shown with the $50 \%$ probability.

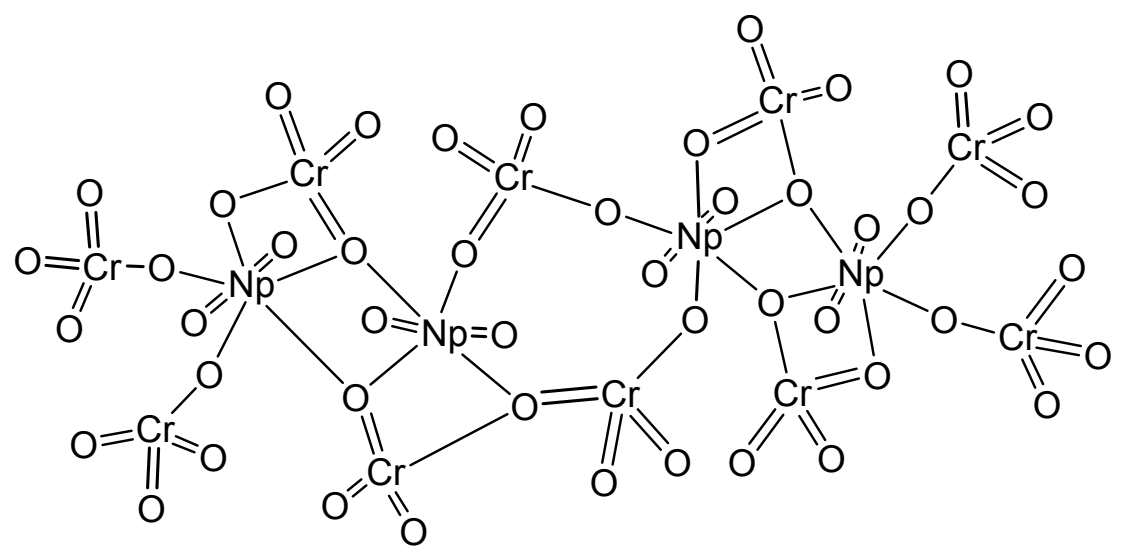

5- and 6-member heterocycles containing $\mathrm{N}$-atoms are also known as ligands in actinide complexes. Thus, the selectivity of N-donor containing ligands such as BTPs (alkylated bis-triazinylpyridines), for actinide complexation in the presence of lantanides, was investigated [29]. NMR studies of an Am $(n \text {-PrBTP })_{3}{ }^{3+}$ complex (Figure 9$)$ with a ${ }^{15} \mathrm{~N}$ labelled ligand showed that it exhibits large differences in $15 \mathrm{~N}$ chemical shift for coordinating $\mathrm{N}$-atoms in comparison to both lanthanide(III) complexes and the free ligand. The temperature dependence of NMR chemical shifts observed for this complex indicated a weak paramagnetism. On the basis of this fact and the observed large chemical shift for bound nitrogen atoms, the authors concluded that metal-ligand bonding in the reported Am(III) N-donor complex has a larger share of covalence than in lanthanide complexes. Also, the interaction between neptunium(IV) and room-temperature ionic liquids \{ $\mathrm{BmimCl}$ (1-butyl-3-methylimidazolium chloride), 
BmimMsu (1-butyl-3-methylimidazolium methylsulfate) and BmimSCN (1-butyl-3-methylimidazolium thiocyanate) $\}$ was studied [30]. They might be useful for the recycling of nuclear fuel and the separation of actinides and fission products from waste solutions.

Figure 9. Structure of $\mathrm{Am}(n-\mathrm{PrBTP}){ }_{3}{ }^{3+}$ complex.

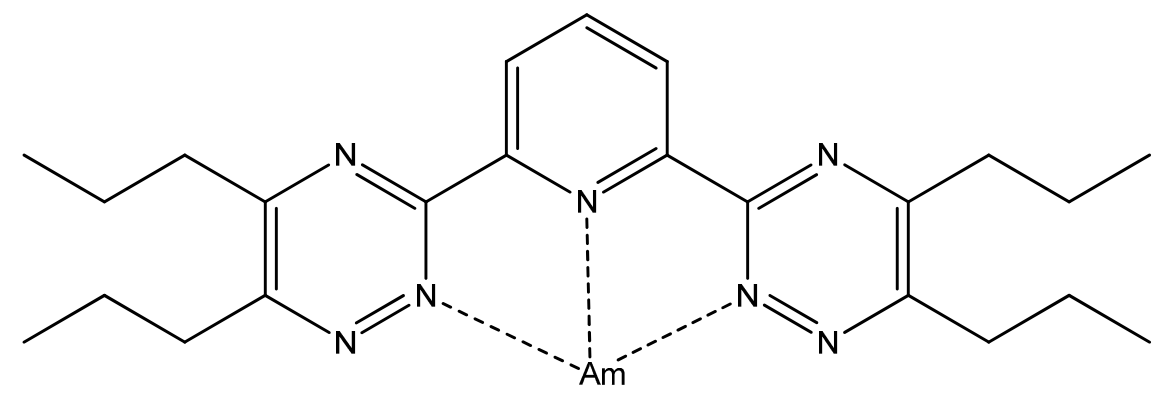

Bipyridine adducts are very common [31-36] for actinide complexes, as well as in whole in coordination chemistry. As an example, the addition of $2,2^{\prime}$-bipyridine to $\left[\mathrm{U}\left(\mathrm{Tp}^{\mathrm{Me} 2}\right)_{2} \mathrm{I}\right]\left\{\mathrm{Tp}^{\mathrm{Me} 2}\right.$ hydro-tris-(3,5-dimethylpyrazolyl)borate ligand\} resulted in the displacement of the iodide and the formation of the cationic uranium(III) complex [U(Tp $\left.{ }^{\mathrm{Me} 2}\right)_{2}$ (bipy)]I, isolated as a dark-green solid in good yield [37]. These complexes exhibit a slow relaxation of magnetization (energy barrier of $18.2 \mathrm{~cm}^{-1}$ ), with a $\mathrm{T}_{\mathrm{c}}$ of $4.5 \mathrm{~K}$ with frequency dependent magnetic properties, characteristic of single-molecule-magnet behavior (currently only the third example of a uranium compound with such behavior). Also, the solid-state structure of the known complex $\left[\mathrm{Et}_{4} \mathrm{~N}\right]\left[\mathrm{U}(\mathrm{NCS})_{5}(\text { bipy })_{2}\right]$ (Figure 10) was re-determined and a detailed spectroscopic and magnetic study was performed in order to confirm the oxidation states of both metal and bipy ligand [38]. On the basis of electronic absorption, infrared spectroscopy data, emission spectroscopy and variable temperature magnetic measurements it was suggested that the uranium is in its +4 oxidation state. The bipy ligands are neutral, innocent ligands and not, as would be inferred from just a solid state structure, radical anions.

Figure 10. Solid-state structure of $\left[\mathrm{Et}_{4} \mathrm{~N}\right]\left[\mathrm{U}(\mathrm{NCS})_{5}(\text { bipy })_{2}\right]$. Selected average bond lengths $(\AA): U-N_{N C S}=2.422 ; U-N_{\text {bipy }}=2.636 ; \mathrm{N}=\mathrm{C}=1.166 ; \mathrm{C}=\mathrm{S}=1.618$.

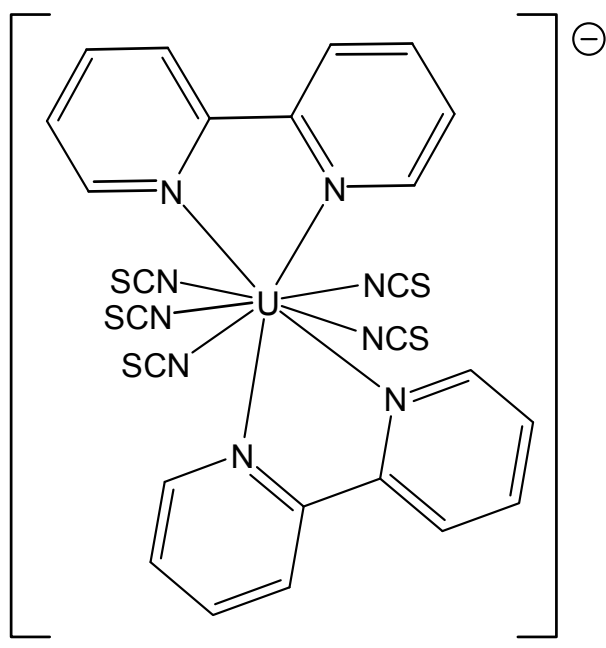


A few examples of actinide macrocycle complexes on the basis of $\mathrm{N}$-containing heterocycles are known. Thus, syntheses of the bimetallic uranium(III) and neptunium(III) complexes [(UI) 2 (L)], $\left[(\mathrm{NpI})_{2}(\mathrm{~L})\right]$, and $\left[\left\{\mathrm{U}\left(\mathrm{BH}_{4}\right)\right\}_{2}(\mathrm{~L})\right]$ (Scheme 3$)$ of the Schiff-base pyrrole macrocycles L are described [39].

Scheme 3. Synthesis of binuclear $\mathrm{U}^{\mathrm{III}}$ and $\mathrm{Np}^{\mathrm{III}}$ complexes of the Schiff-base pyrrolic macrocycles $\mathrm{H}_{4} \mathrm{~L}, \mathrm{H}_{4} \mathrm{~L}^{\prime}$, and $\mathrm{H}_{4} \mathrm{~L}^{\prime \prime}$.
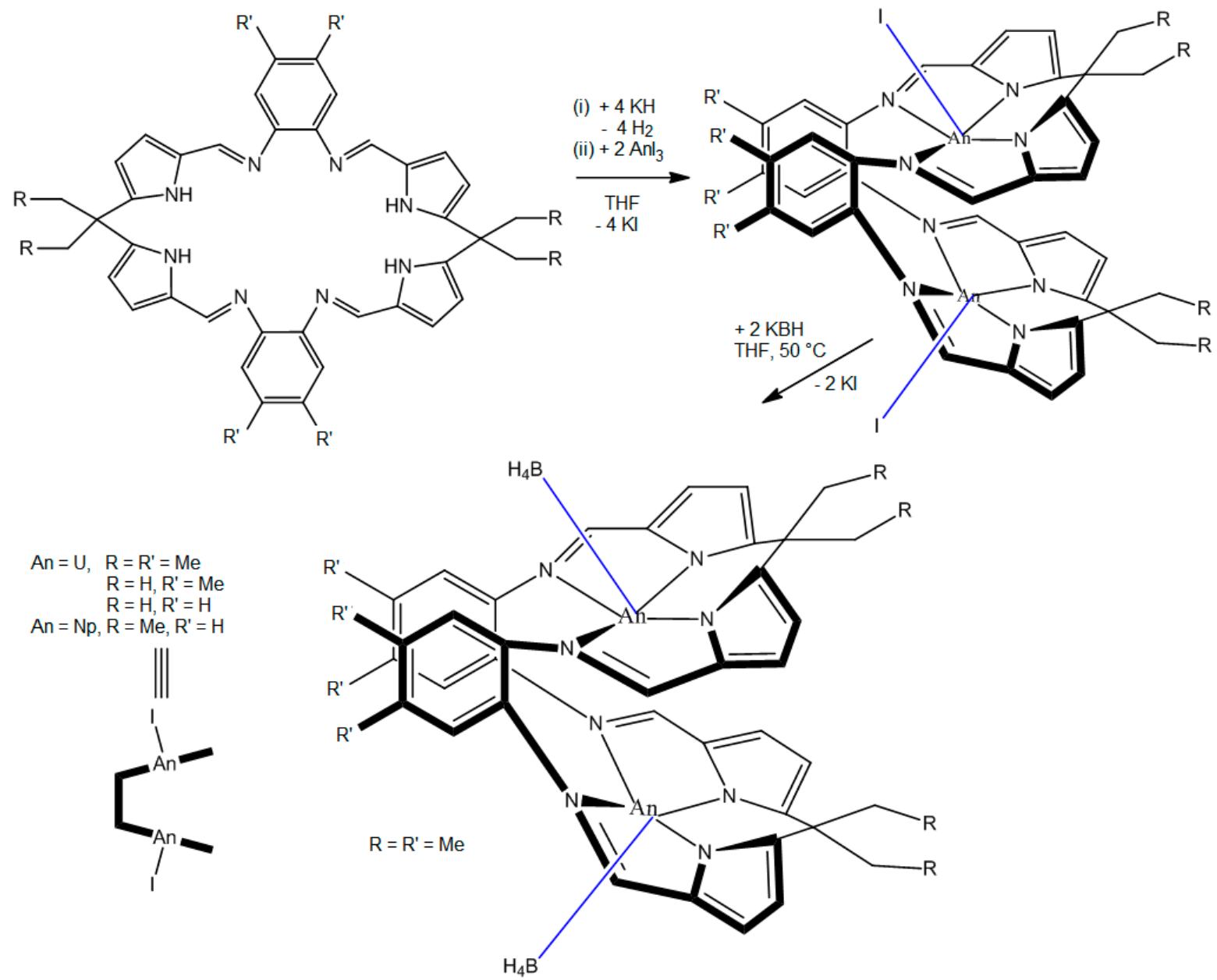

Fitting of the variable-temperature solid-state magnetic data allowed the prediction of polymeric structures for these compounds in the solid state. In addition, thorium(IV) and uranium(IV) macrocycles of $\mathrm{Mes}_{2}(p-\mathrm{OMePh})$ corrole were synthesized [40] via salt metathesis (Scheme 4) with the corresponding lithium corrole in remarkably high yields (93\% and 83\%, respectively). Both complexes are dimeric, having two metal centers bridged via bis( $\mu$-chlorido)linkages. In each case, the corrole ring showed a large distortion from planarity, with the Th(IV) and U(IV) ions residing unusually far (1.403 and $1.330 \AA$, respectively) from the $\mathrm{N}_{4}$ plane of the ligand.

Distinct amines also form a series of complexes with actinide ions. Thus, the extraction of Th(IV) with $\mathrm{N}$ - $n$-octylaniline and trioctylamine (TOA) in xylene, from an acid aqueous sulphuric acid was reported [41]. The effects of varying the concentration of sulphuric acid, N-n-octylaniline and trioctylamine on the distribution ratio of thorium were studied. Based on the obtained results, the possible extraction mechanism is shown in reactions (1-2). The method can be extended to the analysis of thorium in monazite sand and the gas mantle: 


$$
\begin{gathered}
\mathrm{Th}^{4+}+3 \mathrm{SO}_{4}{ }^{2-} \leftrightarrow\left[\mathrm{Th}\left(\mathrm{SO}_{4}\right)_{3}\right]^{2-} \\
\mathrm{mRR}^{\prime}-\mathrm{NH}+\mathrm{nR}_{3}{ }_{3} \mathrm{~N}+\left[\mathrm{Th}\left(\mathrm{SO}_{4}\right)_{3}\right]^{2-} \leftrightarrow \mathrm{mRR}^{\prime} \mathrm{NH}_{2}^{+} \cdot \mathrm{Th}\left(\mathrm{SO}_{4}\right)_{3}{ }^{2-} \cdot n \mathrm{R}_{3}{ }_{3} \mathrm{NH}^{+}
\end{gathered}
$$

where $\mathrm{R}=\mathrm{C}_{6} \mathrm{H}_{5}$ and $\mathrm{R}^{\prime}=\mathrm{R}^{\prime \prime}=\mathrm{C}_{8} \mathrm{H}_{17}$.

Scheme 4. Synthesis of thorium(IV) corrole and uranium(IV) corrole.

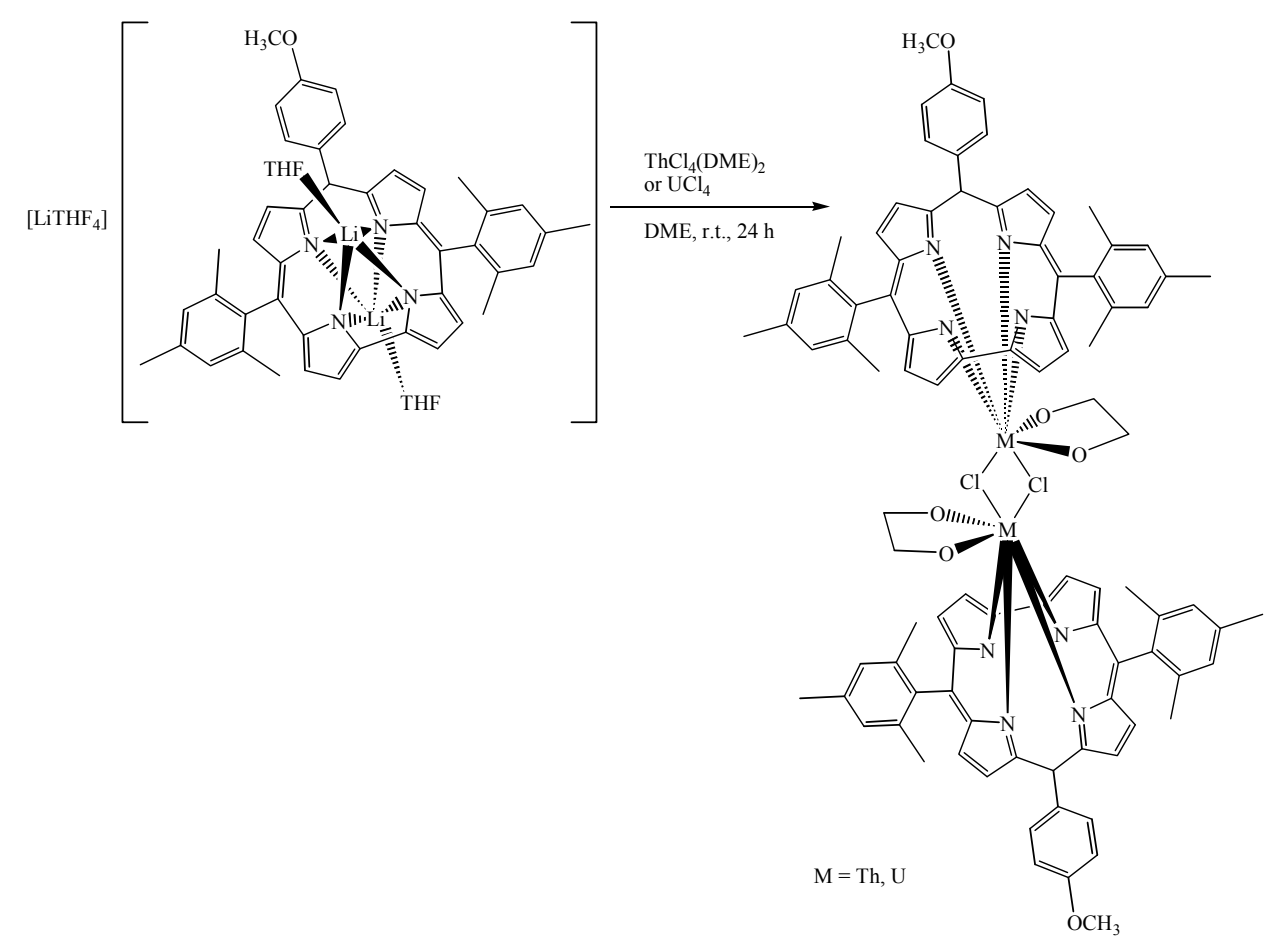

The electronic structures of two uranium compounds supported by redox-active $\alpha$-diimine ligands, $\left({ }^{\mathrm{Mes}} \mathrm{DAB}^{\mathrm{Me}}\right)_{2} \mathrm{U}(\mathrm{THF})$ (Figure 11a) and $\mathrm{Cp}_{2} \mathrm{U}\left({ }^{\mathrm{Mes}} \mathrm{DAB}^{\mathrm{Me}}\right)$ (Figure 11b) $\left({ }^{\mathrm{Mes}} \mathrm{DAB}{ }^{\mathrm{Me}}=\right.$ $[\mathrm{ArN}=\mathrm{C}(\mathrm{Me}) \mathrm{C}(\mathrm{Me})=\mathrm{NAr}] ; \mathrm{Ar}=$ 2,4,6-trimethylphenyl (Mes)), were investigated [42] using both density functional theory and multiconfigurational selfconsistent field methods. It was established that both uranium centers are tetravalent, that the ligands are reduced by two electrons, and that the ground states of these molecules are triplets. Energetically low-lying singlet states are accessible, and some transitions to these states are visible in the electronic absorption spectrum. The computational analysis presented supports the reduction of all $\alpha$-diimine ligands in these compounds by two electrons, which was demonstrated experimentally.

Figure 11. Molecules used for computational study. Aryl groups have been omitted for clarity.

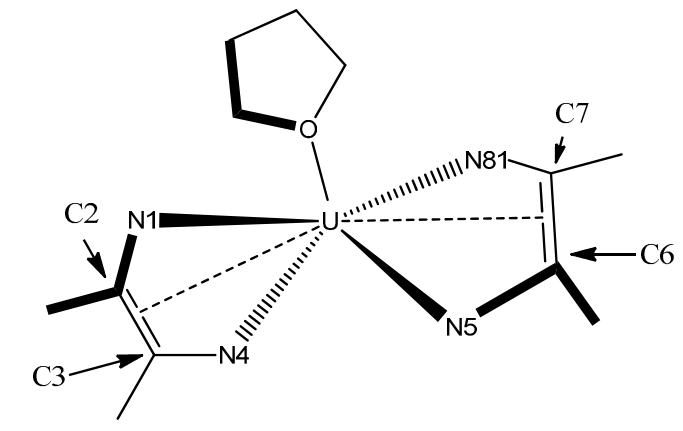

a

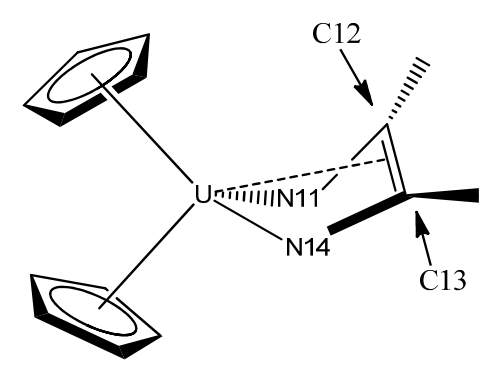

b 
Finally, the fluorinated diarylamines $\mathrm{HNPhPh}^{\mathrm{F}}, \mathrm{HNPh}^{\mathrm{F}}, \mathrm{HNPhAr}^{\mathrm{F}}, \mathrm{Ph}^{\mathrm{F}}=2,3,4,5,6$-pentafluoro-phenyl, $\operatorname{Ar}^{\mathrm{F}}=3,5-b i s($ trifluoromethyl)phenyl, were used to prepare homoleptic complexes of uranium(III, IV) ions from $\mathrm{UI}_{4}\left(\mathrm{Et}_{2} \mathrm{O}\right)_{2}$ (Scheme 5) [43]. Despite being electronpoor amines with little steric bulk, their coordinated amide ligands exhibited direct control over the coordination environment through a subtle, cooperative interplay of multiple labile $\mathrm{F} / \mathrm{U}$ dative interactions and favorable arene-arene interactions.

Scheme 5. Synthesis of uranium(IV) diarylamide complexes from $\mathrm{UI}_{4}\left(\mathrm{Et}_{2} \mathrm{O}\right)_{2}$.<smiles>c1ccc(Nc2ccccc2)cc1</smiles>

$\mathrm{HNPh}_{2}$<smiles>FC(F)(F)c1ccc(Nc2ccccc2)cc1C(F)(F)F</smiles>

$\mathrm{HNPhAr}{ }^{\mathrm{F}}$<smiles>c1ccc(N(c2ccccc2)N(c2ccccc2)[N+](c2ccccc2)(c2ccccc2)N(c2ccccc2)c2ccccc2)cc1</smiles>
$\left(1-\mathrm{Ph}_{2}\right)$

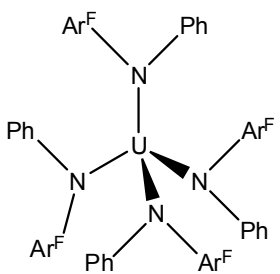

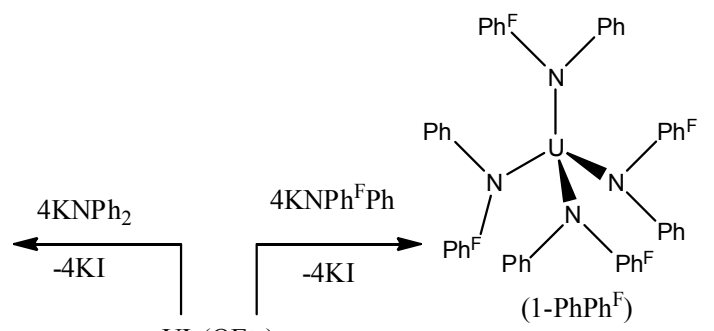<smiles>Fc1c(F)c(F)c(Nc2ccccc2)c(F)c1F</smiles>
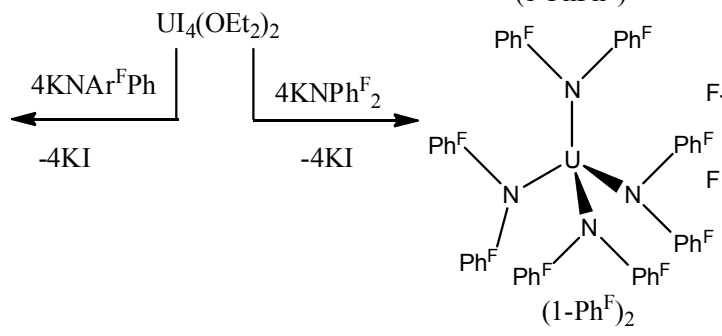<smiles>Fc1c(F)c(F)c(Nc2c(F)c(F)c(F)c(F)c2F)c(F)c1F</smiles>

Containing extremely large metal atoms, actinide complexes could have unusual structural characteristics. Thus, the synthesis and studies of the first 15-coordinate complex (Figure 12) was reported [44].

Figure 12. Molecular structure of $\left[\mathrm{Th}\left(\mathrm{H}_{3} \mathrm{BNMe}_{2} \mathrm{BH}_{3}\right)_{4}\right]$ from neutron diffraction data. Ellipsoids are drawn at the $20 \%$ probability level. Th orange, B tan, N purple, C black, H blue.

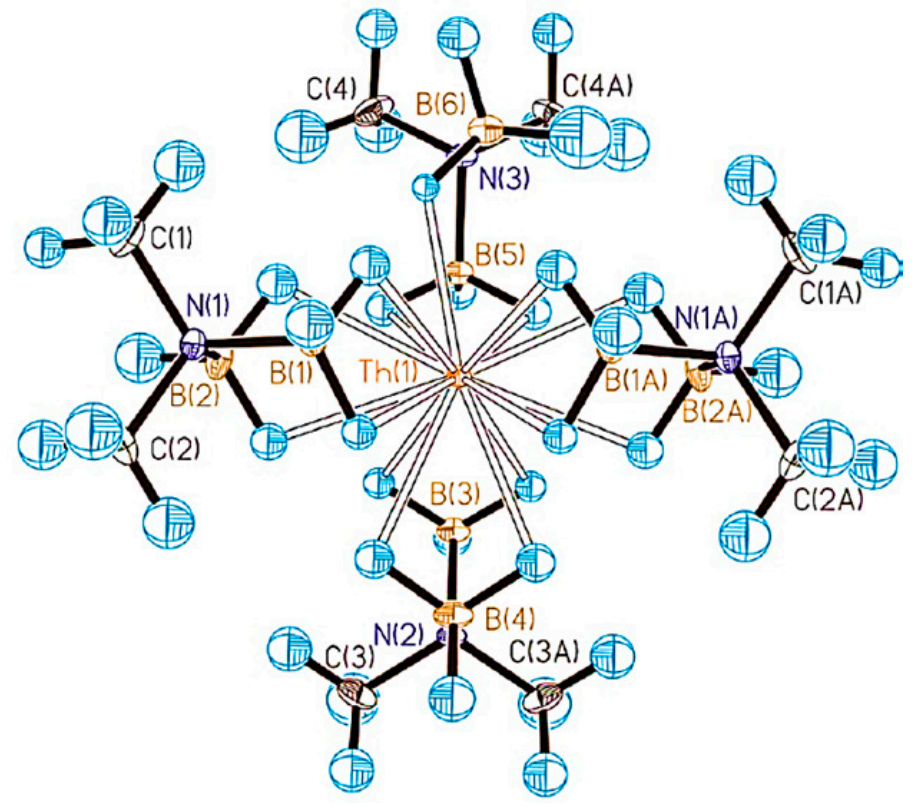

Reaction of $\mathrm{ThCl}_{4}$ with four equivalents of sodium N,N-dimethylaminodiboranate, $\mathrm{Na}\left(\mathrm{H}_{3} \mathrm{BNMe}_{2} \mathrm{BH}_{3}\right)$, in THF produced $\left[\mathrm{Th}\left(\mathrm{H}_{3} \mathrm{BNMe}{ }_{2} \mathrm{BH}_{3}\right)_{4}\right]$, which could be isolated as colorless 
prisms by crystallization from diethyl ether. DFT calculations suggested that this complex may adopt a 16-coordinate structure in the gas phase. The isolated molecule has full $D_{2 d}$ symmetry with a coordination number of 16 , but that the crowded nature of the inner coordination sphere is sufficiently destabilizing that molecule distorts and becomes 15-coordinate in the solid state. This is the hightest Werner coordination number for a metal complex reported to the date, and was made possible by combining a very large metal atom with very small ligands.

\section{A.3.2. Actinide Complexes with N,O-and N,S-Containing Ligands}

A series of N,O- and some N,S-containing ligands are represented by a series of Schiff bases, iminoacetates and other amino/amido/imino derivatives, among others. Thus, the stability and the associated thermodynamic parameters of the binary and the ternary complexes of trivalent $\mathrm{Am}$ and $\mathrm{Cm}$ with iminodiacetate (IDA, Figure 13) and with EDTA+IDA, were determined by using a solvent extraction technique for aqueous solutions of $\mathrm{I}=6.60 \mathrm{~m}\left(\mathrm{NaClO}_{4}\right)$ at temperatures of $0-60{ }^{\circ} \mathrm{C}$ [45]. The endothermic enthalpy and the positive entropy reflected the significant effect of dehydration in the formation of these complexes at high ionic strength.

Figure 13. IDA (iminodiacetate).

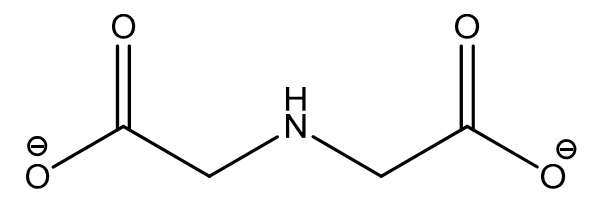

Functionalized bitopic terpyridine(tpy)-diamide N,O-ligands (Figure 14) were recently developed for the group actinide separation by solvent extraction. In order to acquire a better understanding of their coordination mode in solution, the protonation and the formation of Am(III) and U(VI) complexes with bitopic N,O- containing ligands in methanol/water homogeneous mixtures was studied [46]. When the terpyridine moiety contained amide functional groups, the extracting properties of these ligands was improved, due tochanges in their basicity. Two predominant inner-sphere coordination modes were found from the DFT calculations: one mode where the cation is coordinated by the nitrogen atoms of the cavity and by the amide oxygen atoms and the other mode where the cation is only coordinated by the two amide oxygen atoms and by solvent molecules.

Figure 14. Structure of tpy ligands.

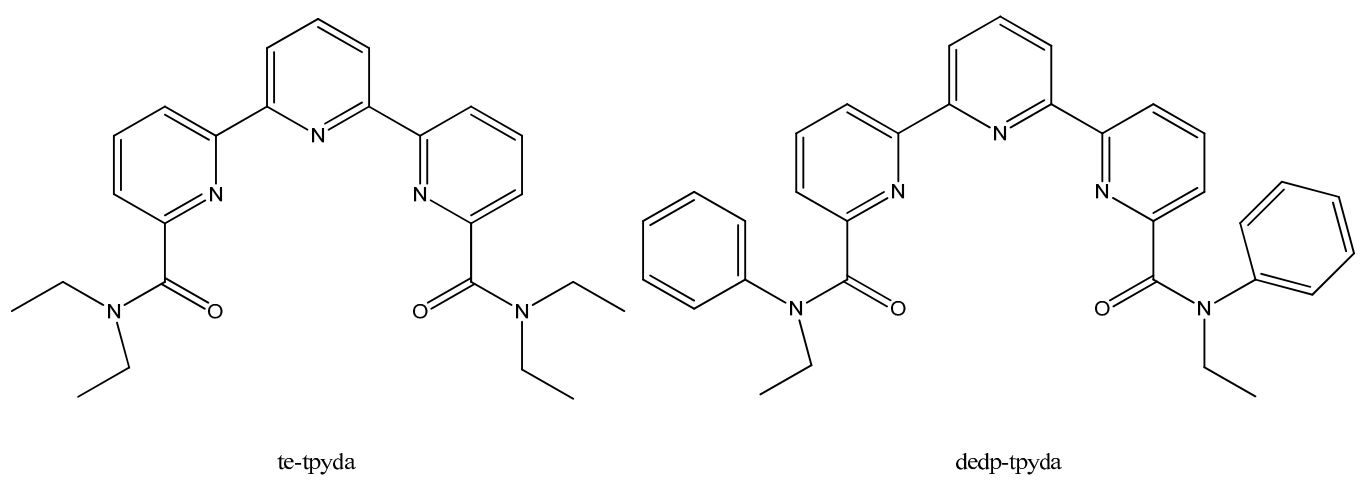


Also, it was demonstrated that an uranium(III) tris(amide) complex was capable to selectively couple $\mathrm{CO}$ into a linear ynediolate $[\mathrm{OCCO}]^{2-}$ dianion, at ambient conditions (room temperature and atmospheric pressure), in catalytic concentrations (Scheme 6) [47].

Scheme 6. Coupling and functionalization of carbon monoxide by the trivalenturanium amide to form a uranium-coordinated ynediolate $\mathbf{1}$, and then an ene-diolate $\mathbf{2}$.
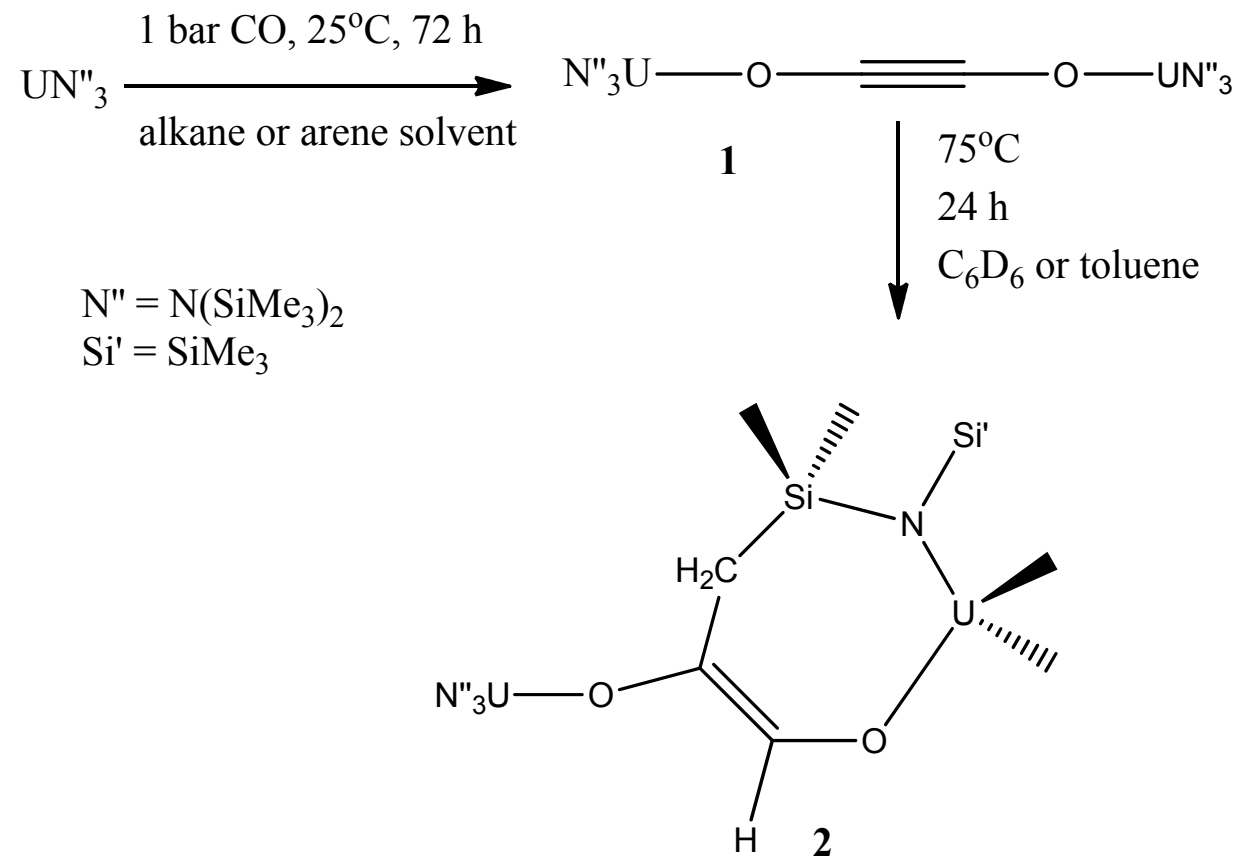

This compound was able, warming the mixture, to activate a $\mathrm{C}-\mathrm{H}$ bond of a methyl group across the $\mathrm{CC}$ triple bond, forming a new $\mathrm{CC}$ bond and generating a functionalized enediolate dianion. As a great contribution of this research for the area of reductive activation reactions of small, traditionally inert molecules such as dinitrogen and carbon dioxide, demonstrated for trivalent uranium complexes, the observed ready interconversion between the $\mathrm{U}^{\mathrm{III}}$ and $\mathrm{U}^{\mathrm{IV}}$ oxidation states suggested that catalytic systems based on this coupling and functionaliation are viable. It is notable that the reaction occurs with such a simple coordination compound - an amide that is made from simple commercially available ligands (the precursor amide salt currently costs under $€ 100$ per mol). In addition, under mild conditions a simple triamidoamine uranium(III) complex (Scheme 7) can reductively homologate CO and be recycled for reuse [48].

Scheme 7. Reaction of $\mathrm{CO}$ with uranium complex $\left(\mathrm{R}=\mathrm{SiMe}_{2} \mathrm{Bu}^{t}\right)$.
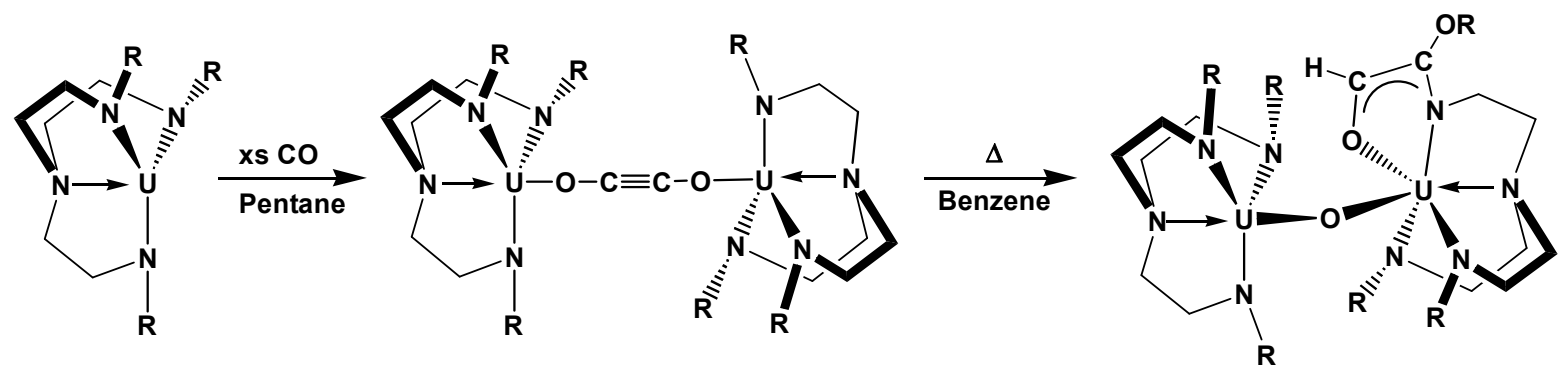
Structural analyses of uranyl complexes with isomers of $N, N^{\prime}$-diethyl- $N, N^{\prime}$-ditolyldipicolinamide (EtTDPA, Figure 15) were carried out using IR spectroscopy and single crystal X-ray diffraction [49]. From these analyses, it was determined that complexation takes place through coordination with the carbonyl and pyridine nitrogen moieties.

Figure 15. Structures of (a) Et(o)TDPA, (b) Et(m)TDPA, (c) Et(p)TDPA.<smiles>CCN(C(=O)c1cccc(N(CC)C(=O)c2cccc(C(=O)N(CC)c3cccc(C)c3)n2)c1)c1cccc(C(=O)N(CC)c2cccc(C(=O)N(CC)c3cccc(C)c3)n2)c1</smiles>

The uranyl complexes showed space groups of Pbca for Et(p)TDPA and P21/n for Et(o)TDPA. Also, the magnetic properties of the triangular molecular nanomagnet $\left[\mathrm{UO}_{2} \mathrm{~L}\right]_{3} \quad\{\mathrm{~L}=2-(4-\mathrm{tolyl})-1,3-$ bis(quinolyl)malondiiminate\} were investigated through electron paramagnetic resonance spectroscopy, high-field magnetization and susceptibility measurements [50]. The results showed that $\left[\mathrm{UO}_{2} \mathrm{~L}\right]_{3}$ has a non-magnetic groud state (doublet) due to the chiral arrangement of the uranium magnetic moments to two opposite positions. Quantum tunneling of the non-collinear magnetization, in the presence of a perpendicular external magnetic field results explains its non-axial character of the single-ion crystal field.

Figure 16. Structure of the suggested metal complex.

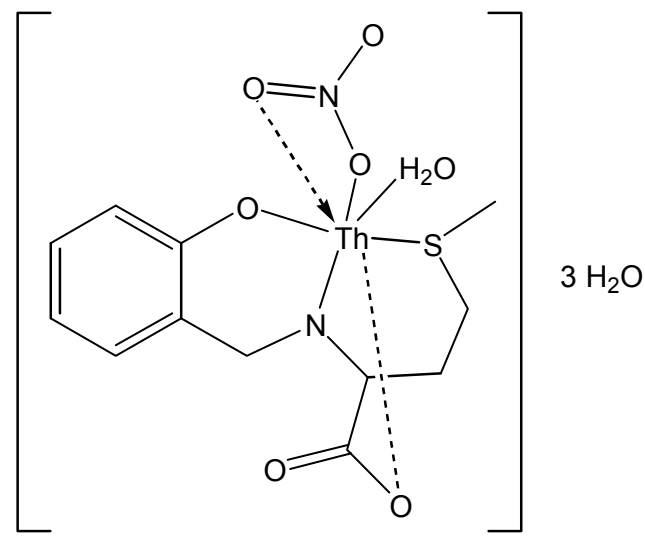

Metal complex (Figure 16) of Th(IV), with the amino Schiff base ligand, [N-(2-hydroxybenzyl)-Lmethionine acid] $\left(\mathrm{H}_{3} \mathrm{~L}\right.$, Figure 17), was prepared in the presence of triethylamine as a deprotonating 
agent [51]. The data from thermogravimetricanalysis clearly indicated that its decompositionproceeds in four or five steps and theorganic part decomposed in one or twointermediates. The decomposition of the complex ended with metal oxide and carbon residue.

Figure 17. 2-(2-Hydroxybenzylamino)-4-(methylthio)butanoic acid.<smiles>CSCCC(NCc1ccccc1O)C(=O)O</smiles>

The Schiff bases and their complexes were screened for their antibacterial (E. coli, Staphylococcus aureus) and antifungal (Aspergillus flavus and Candida albicans) activities. Several Th(IV) and $\left[\mathrm{UO}_{2}\right]^{+2}$ complexes with Schiff base ligands prepared from $p$-trimethoxybenzaldehyde, $p$-hydroxy-benzaldehyde and 2-aminopyridine (Figure 18) were prepared and their structures and physical and chemical properties reported (Figure 19) [52].

Figure 18. (a) $2 N$-[3,4,5-trimethoxybenzylidene $]$ aminopyridine and (b) $2 N$-[4hydroxybenzylidene]aminopyridine.

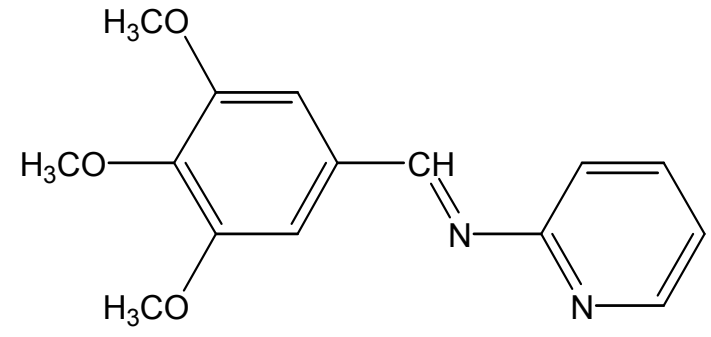

(a) 2-TBAPy

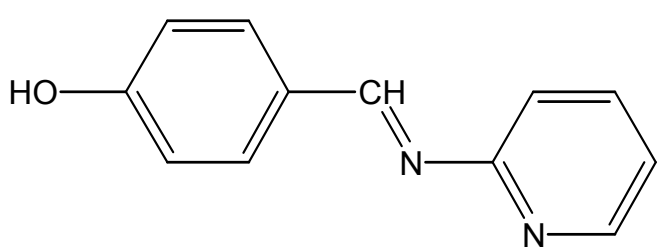

(b) 2-HBAPy

Figure 19. The proposed coordination numbers and structures for selected thorium complexes of 2-TBAPy and 2-HBAPy.
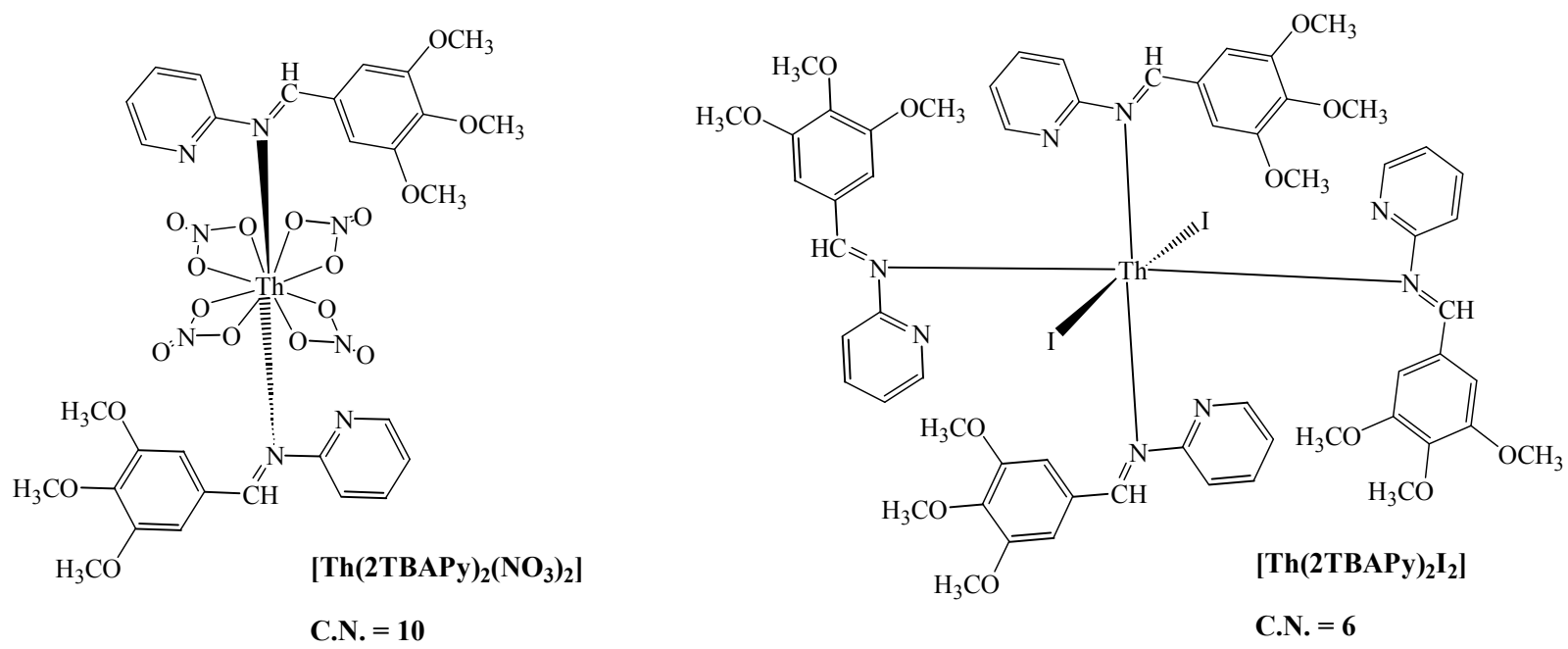
Figure 19. Cont.

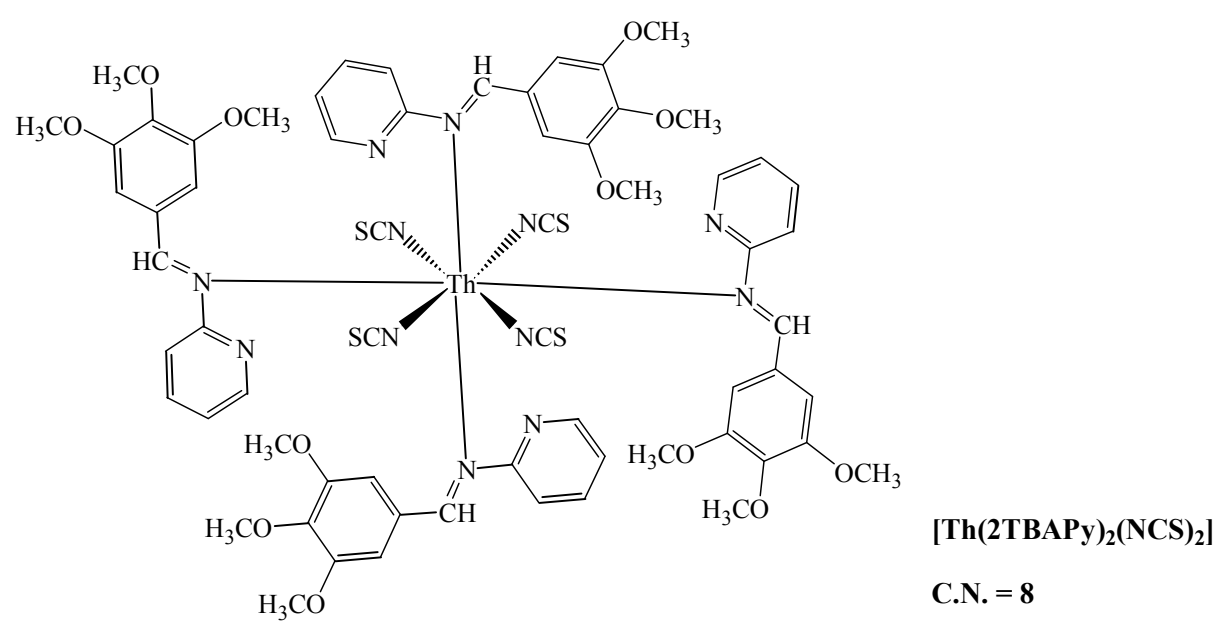

These complexes present a wide range of coordination numbers (from 6 to 10), and some of them have antibacterial and antifungal action. In addition, light yellow thorium(IV) six-coordinate complexes were synthesized by reacting Th(IV) nitrate with Schiff bases (Figure 20) derived from 3-substituted-4-amino-5-mercapto-1,2,4-triazole and glyoxal/biacetyl/ benzyl in ethanol [53]. All these complexes are insoluble in DMF and DMSO. The involvement of both $\mathrm{C}=\mathrm{N}$ groups in the complex formation was suggested, keeping SH groups away from the coordination (Figure 21).

Figure 20. Schiff bases derived from 3-substituted-4-amino-5-mercapto-1,2,4-triazole.<smiles>[R]C(=Nn1c([R])nnc1[R])C([R])=Nn1c([R])nnc1[R]</smiles>

Figure 21. Proposed structure of thorium Schiff-base complexes.<smiles>[R]C1=C([N+](=O)[O-])[N+](O)([N+](=O)[O-])[C@@](O)(n2c([R])nnc2[R])N(n2c([R])nnc2[R])C1[R]</smiles>

Dioxouranium(VI) and thorium(IV) complexes of ONO-hydrazone ligand derived from 2-hydroxy-5methylacetophenone and 2-furoic acid hydrazide (Figure 22) were synthesized and characterized [54]. 
Figure 22. Hydrazone ligand derived from 2-hydroxy-5-methylacetophenone and 2-furoic acid hydrazide.<smiles>Cc1ccc(O)c(C(C)O)c1</smiles><smiles>CC(C)=NNC(=O)c1ccco1</smiles><smiles>C/C(=N/N=C(\O)c1ccco1)c1cc(C)ccc1O</smiles>

The compounds show semiconductingbehavior as their conductivity increases with increasing temperature. The ligand and its complexes have also been screened for their antibacterial and antifungal activities. The isolated complexes are bright in color, quite air stable, can be stored for long periods, insoluble in water, soluble to very limited extent in common organic solvents but to a considerable extent in DMF and DMSO. Other hydrazone complexes also possess useful applications. For instance, thorium(IV) forms a yellow colored water soluble complex with diacetyl monoxime isonicotinoyl hydrazone reagent DMIH (Figure 23) in acidic buffer of $\mathrm{pH} 5.0$ with $\lambda_{\max }$ at $352 \mathrm{~nm}$ [55]. This simple method using DMIH as a spectrophotometric reagent can be applied for the determination of thorium(IV) in aqueous medium.

Figure 23. Structure of diacetyl monoxime isonicotinoyl hydrazone (DMIH).<smiles>CC(=NNC(=O)c1ccncc1)/C(C)=N/O</smiles>

Mixed-ligand diamagnetic Th(IV) complexes (Figure 24) of the type $\left[\mathrm{M}(\mathrm{Q})(\mathrm{L})\left(\mathrm{NO}_{3}\right)_{2}\right]^{\cdot} 2 \mathrm{H}_{2} \mathrm{O}$ were synthesized [56] using 8-hydroxyquinoline as a primary ligand and $\mathrm{N}$ - and/or O-donor amino acids such as L-threonine, L-tryptophan and L-isoleucine as secondary ligands. 
Figure 24. Proposed structures and bonding for the 8-hydroxyquinoline complexes.

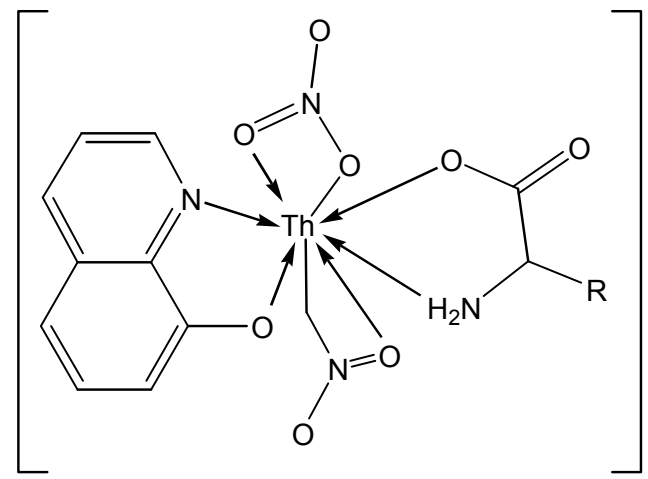<smiles>[R][CH]C(C)O</smiles><smiles>[R]=CC1CNc2ccccc21</smiles><smiles>[R]=[Ni]</smiles>

Figure 25. Diazepam [7-chloro-1-methyl-5-phenyl-3H-1,4-benzodiazepine-2-one].<smiles>CN1C(=O)CN=C(c2ccccc2)c2cc(Cl)ccc21</smiles>

The electrical conductance studies of the complexes in DMF in $10^{-3} \mathrm{M}$ concentration indicate their non-electrolytic nature. Bonding of the metal ion takes place through $\mathrm{N}$ - and O-donor atoms of the ligands. In addition, complexes of diazepam (DZM, Figure 25) with the metal nitrates of thorium and uranium were synthesized [57]. The complexes were found to have the general composition $\left[\mathrm{L}\left(\mathrm{M}^{1}\right)\left(\mathrm{NO}_{3}\right)_{4}\right]$ and $\left[\mathrm{L}\left(\mathrm{M}^{2}\right)\left(\mathrm{NO}_{3}\right)_{2}\right]$, where $\mathrm{L}=$ ligand $(\mathrm{DZM}), \mathrm{M}^{1}=\mathrm{Th}(\mathrm{IV})$ and $\mathrm{M}^{2}=\mathrm{UO}_{2}(\mathrm{II})$. The complexes were proposed to be octahedral in geometry. The ligand and its metal complexes were screened for their antimicrobial activities on bacteria (E. coli, S. typhi, B. subtilis and S. aureus) and fungi (A. niger, A. flavous, P. triticena and F. species). Among other recently reported actinide complexes, we note those with amido/amino phenol ligands [58,59] and containing both sulfonate and carboxylate groups [60] . 


\section{A.4. Actinide Complexes with Calixarenes}

Calixarenes (in particular phosphinoylated calixarenes as $p$-tert-butylcalix[4]arene, forming stable thorium complexes with 1:1 and 1:2 stoichiometries in organic media [61], or calixarene-based picolinamides and malonamides [62]) feature high coordination ability toward $f$ elements and a great potential for actinide/rare earth separation. In particular, they are applied as as macrocyclic ligands for uranium(VI) [63], showing endo- and exocavity binding in uranyl-calix[6]arene complexes (Figure 26). Calixarene complexes are mainly used for analytical or extraction/separation purposes. Thus, a new class of calixarene analogues, pillar[5]arenes, having ten diglycolamide (DGA) pendant groups as arms on both rims of the pillar structure, were prepared and their affinity toward Am(III) and $\mathrm{Eu}$ (III) evaluated, as potential novel chelating agents for rare-earth and actinide extraction (Scheme 8) [64].

Figure 26. Endo- and exocavity binding in uranyl-calix[6]arene complexes.

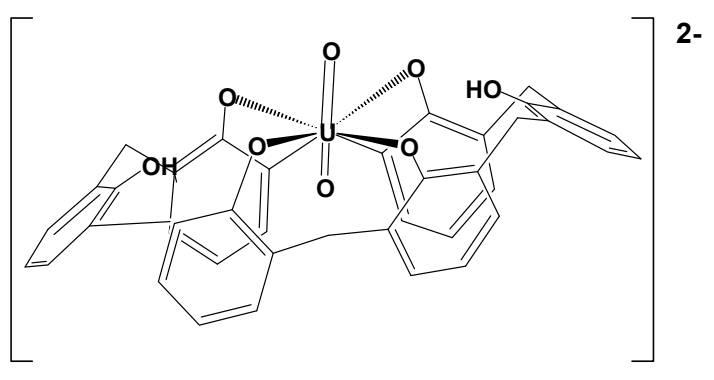

Endo

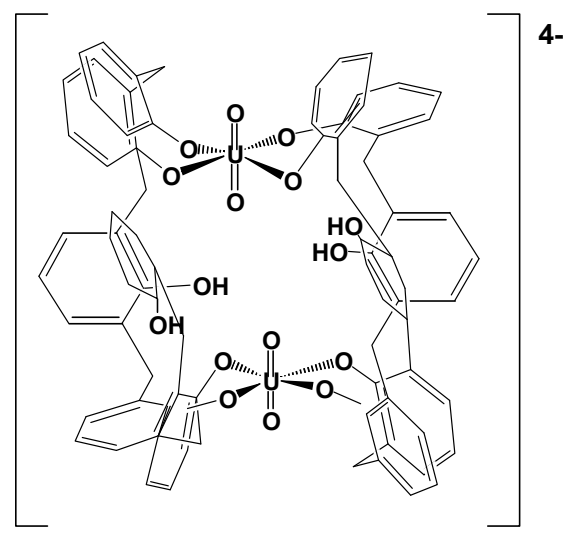

Exo

Scheme 8. The extraction of trivalent $\mathrm{Am}(\mathrm{III})$ and $\mathrm{Eu}(\mathrm{III})$ cations with three novel pillar[5]arenes substituted by ten diglycolamide groups (P5DGAs).

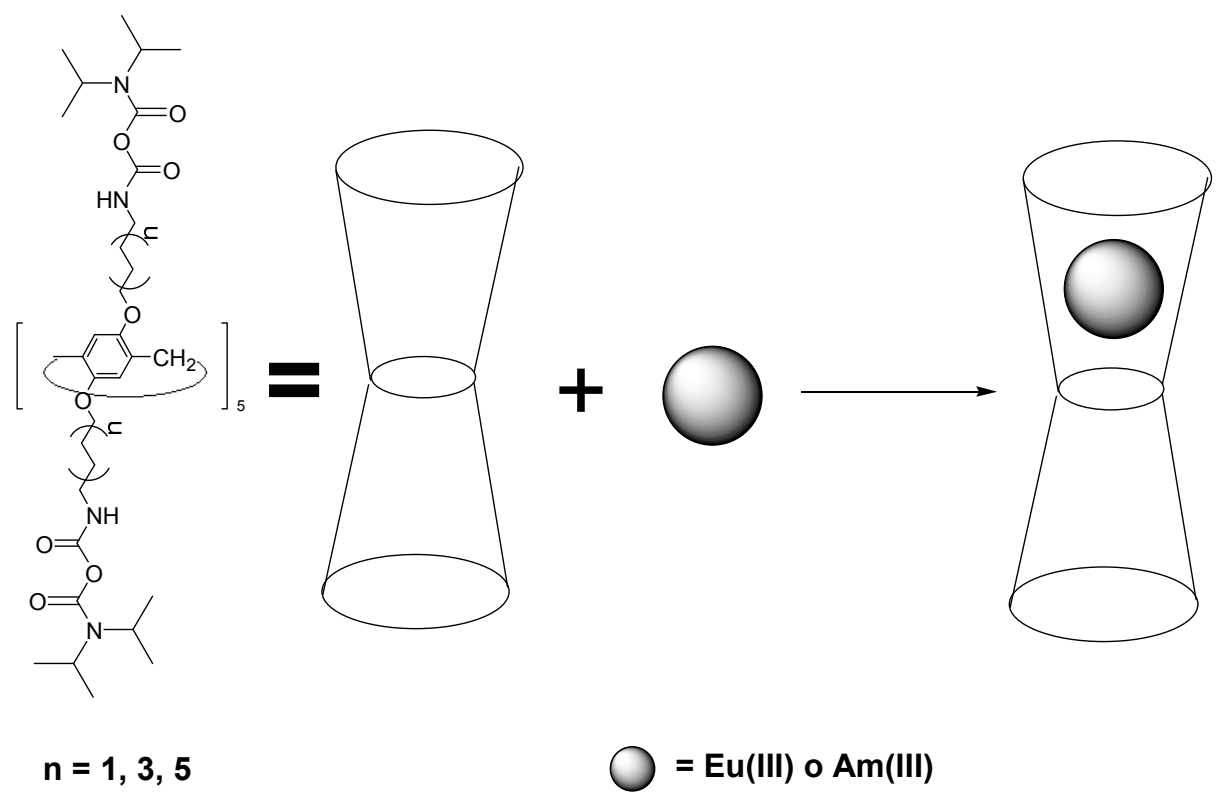


These extractants exhibited excellent separation and extraction efficiency, suggesting its significant potential for nuclear waste remediation. Laser induced fluorescence experiments disclosed strong complexation of the trivalent metal ions with the pillararene-DGA ligands. As a new class of extractants with a framework of pillar conformation that is quite different from the calixarene extractants, pillararene-based diglycolamides may hold potential for the efficient separation of $\mathrm{Eu}(\mathrm{III})$ and Am(III) from radioactive liquid nuclear waste. In addition, application of azocalixarene for evaluation of thorium content based on the complex of $o$-ester tetraazophenylcalix[4]arene (TEAC, Figure 27) with thorium(IV) in acetate buffer solution was offered [65]. This recommended method could be applied for determination of thorium concentration in some monazite ore with high confident results.

Figure 27. Structure of TEAC.

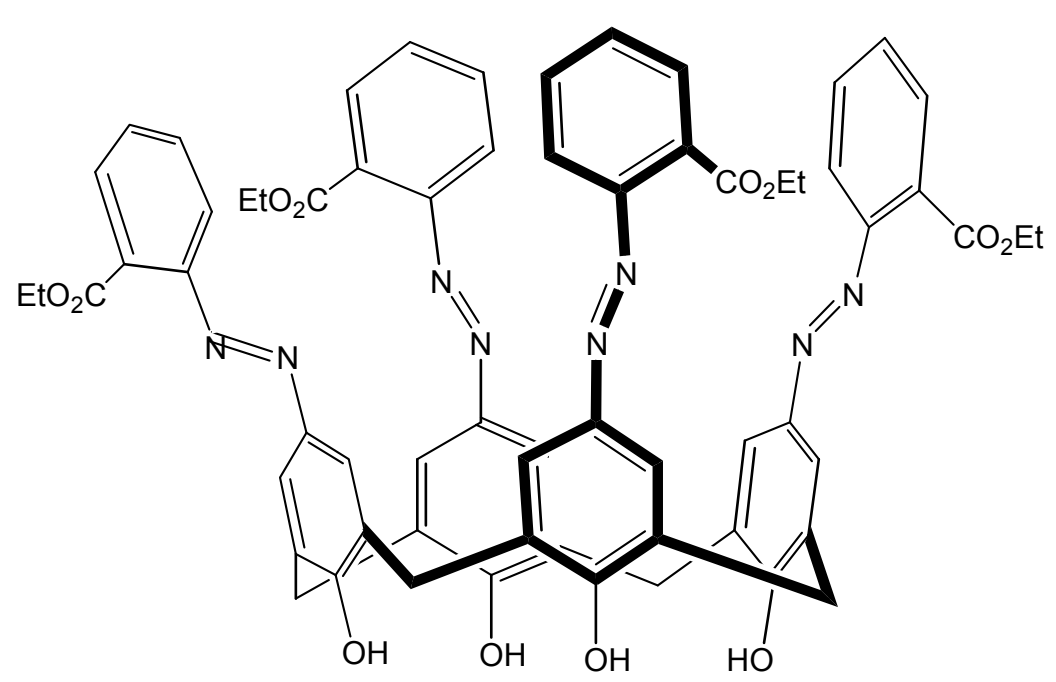

\section{A.5. Actinide Complexes with P-Containing Ligands}

A few P-containing actinide complexes have been recently reported with classic P-ligands. Thus, $\left(\mathrm{Ph}_{4} \mathrm{P}\right)_{2} \mathrm{UO}_{2} \mathrm{I}_{4} 2 \mathrm{NCCH}_{3}$ was prepared [66] according to the reaction (3). The redcrystals were soluble in $\mathrm{MeCN}$, but decomposed quickly insolvents such as methanol or THF. It was noted that, whereas $\mathrm{UO}_{2} \mathrm{I}_{2} \times \mathrm{H}_{2} \mathrm{O}$ is thermally unstable in the solid state at room temperature, the neutral $\mathrm{UO}_{2} \mathrm{I}_{2}\left\{\mathrm{OP}\left(\mathrm{NMe}_{2}\right)_{3}\right\}_{2}, \mathrm{UO}_{2} \mathrm{I}_{2}\left(\mathrm{OPPh}_{3}\right)_{2}$, and $\mathrm{UO}_{2} \mathrm{I}_{2}(\text { py })_{3}$, as well as $\left(\mathrm{Ph}_{4} \mathrm{P}\right)_{2} \mathrm{UO}_{2} \mathrm{I}_{4} \cdot 2 \mathrm{NCCH}_{3}$, are all stable in the solid state at r.t. Extraction of $\mathrm{Am}$ (III) and $\mathrm{Cm}(\mathrm{III})$ [67], as well as $\mathrm{Np}$ (VI) [68], between tri- $n$-butyl phosphate solution and molten calcium nitrate hydrate $\mathrm{Ca}\left(\mathrm{NO}_{3}\right)_{2} \cdot \mathrm{RH}_{2} \mathrm{O}$ was investigated radiochemically. The extraction reaction of $\mathrm{Am}$ and $\mathrm{Cm}$ in the $\mathrm{Ca}\left(\mathrm{NO}_{3}\right)_{2} \cdot \mathrm{RH}_{2} \mathrm{O}-\mathrm{TBP}$ system is considered to be the same as the reaction in the $\mathrm{HNO}_{3}$-TBP system (4). The distribution ratio was found to be inversely related to the water activity (in the range of water content $R=3.5-8.0$ ). This dependence in the hydrate melt changes according to $\log a_{\mathrm{H} 2 \mathrm{O}}=-0.4$, which corresponds to $R=5.0$. The distribution of $\mathrm{Np}$ (IV) between $0.08-4.5 \mathrm{M} \mathrm{HNO}_{3 \text { (aq,eqm) }}$ and $\approx 30 \%$ tri- $n$-butyl phosphate was modelled, accounting for the formation of $1: 1$ and $1: 2$ nitrate complexes and $\mathrm{Np}(\mathrm{IV})$ hydrolysis in the aqueous phase and the extraction of $\mathrm{Np}\left(\mathrm{NO}_{3}\right)_{4}(\mathrm{TBP})_{2}$ into TBP [69]. In addition, the role of water in the formation of associates from nanosized complexes of uranium in a supercritical carbon dioxide $\left(\mathrm{SC} \mathrm{CO}_{2}\right)$ medium was studied [70]. It was found experimentally that water in the $\mathrm{SC} \mathrm{CO}_{2}$ exists in the form of microdrops and at a pressure of $10 \mathrm{MPa}$ and a temperature of $40{ }^{\circ} \mathrm{C}$ the 
$\mathrm{UO}_{2}\left(\mathrm{NO}_{3}\right)_{2} \cdot 2\left(\mathrm{C}_{4} \mathrm{H}_{9} \mathrm{O}\right)_{3} \mathrm{PO}$ (TEP) complex (Figure 28) may take on hydrophilic properties. The complex above would concentrate in water microdrops, and its concentration in water microdrops gives rise to the formation of associates, the size of which was determined by microdrop dimensions.

$$
\begin{gathered}
\mathrm{UO}_{2} \mathrm{I}_{2} x \mathrm{H}_{2} \mathrm{O}+2 \mathrm{Ph}_{4} \mathrm{PI} \rightarrow\left(\mathrm{Ph}_{4} \mathrm{P}\right)_{2} \mathrm{UO}_{2} \mathrm{I}_{4}+x \mathrm{H}_{2} \mathrm{O} \\
\mathrm{M}\left(\mathrm{H}_{2} \mathrm{O}\right)_{n}{ }^{3+}+3 \mathrm{NO}_{3}{ }^{-}+3 \mathrm{TBP} \rightarrow \mathrm{M}\left(\mathrm{NO}_{3}\right)_{3} 3 \mathrm{TBP}+n \mathrm{H}_{2} \mathrm{O}
\end{gathered}
$$

where $\mathrm{M}$ indicates $\mathrm{Am}$ or $\mathrm{Cm}$ and $n$ indicates the hydration number.

Figure 28. Schematic diagram of complex structure $\mathrm{UO}_{2}\left(\mathrm{NO}_{3}\right)_{2} \cdot 2 \mathrm{TEP}$.

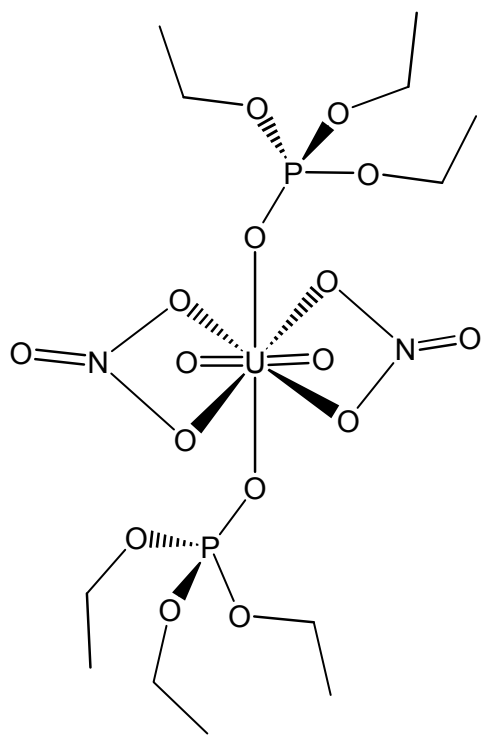

\section{A.6. Actinide Organometallic Complexes}

A series of actinide organometallics is known, mainly metallocene-like complexes of uranium and thorium \{although the arene-bridged complex ( $\mu$-toluene) $\mathrm{U}_{2}(\mathrm{~N}[t \mathrm{Bu}] \mathrm{Ar})_{4}\left(\mathrm{Ar}=3,5-\mathrm{C}_{6} \mathrm{H}_{3} \mathrm{Me}_{2}\right)$ is also known [71] \}. Thus, gas/solid reactions involving $\mathrm{H}_{2}$ and $\mathrm{CO}_{2}$ with the metallocenes $\left(\mathrm{C}_{5} \mathrm{Me}_{5}\right)_{2} \mathrm{UMe}_{2}$ and $\left(\mathrm{C}_{5} \mathrm{Me}_{5}\right)_{2} \mathrm{U}(\text { allyl })_{2}$ as solids in the absence of solvent provided an improved method to make organouranium hydride and carboxylate products (Schemes 9-11) [72].

Scheme 9. Reaction of solid $\left(\mathrm{C}_{5} \mathrm{Me}_{5}\right)_{2} \mathrm{UMe}_{2}$ with $\mathrm{H}_{2}$ gas.

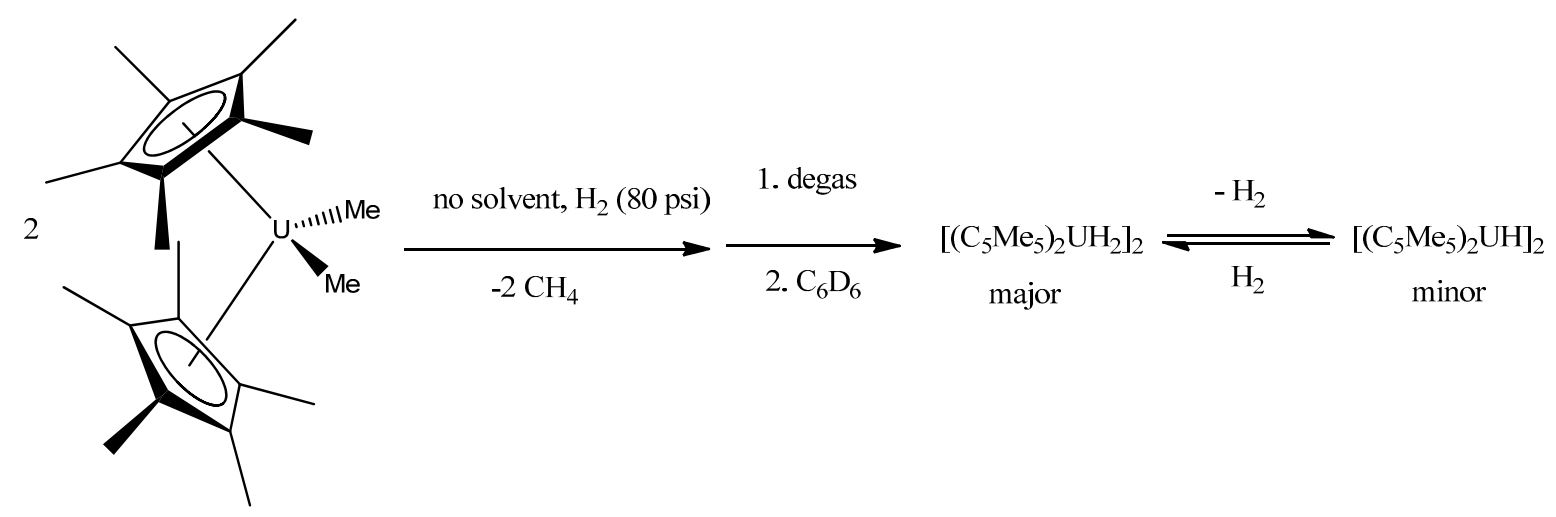


Scheme 10. Reaction of solid $\left(\mathrm{C}_{5} \mathrm{Me}_{5}\right)_{2} \mathrm{U}\left(\mathrm{C}_{3} \mathrm{H}_{5}\right)_{2}$ with $\mathrm{H}_{2}$ gas.

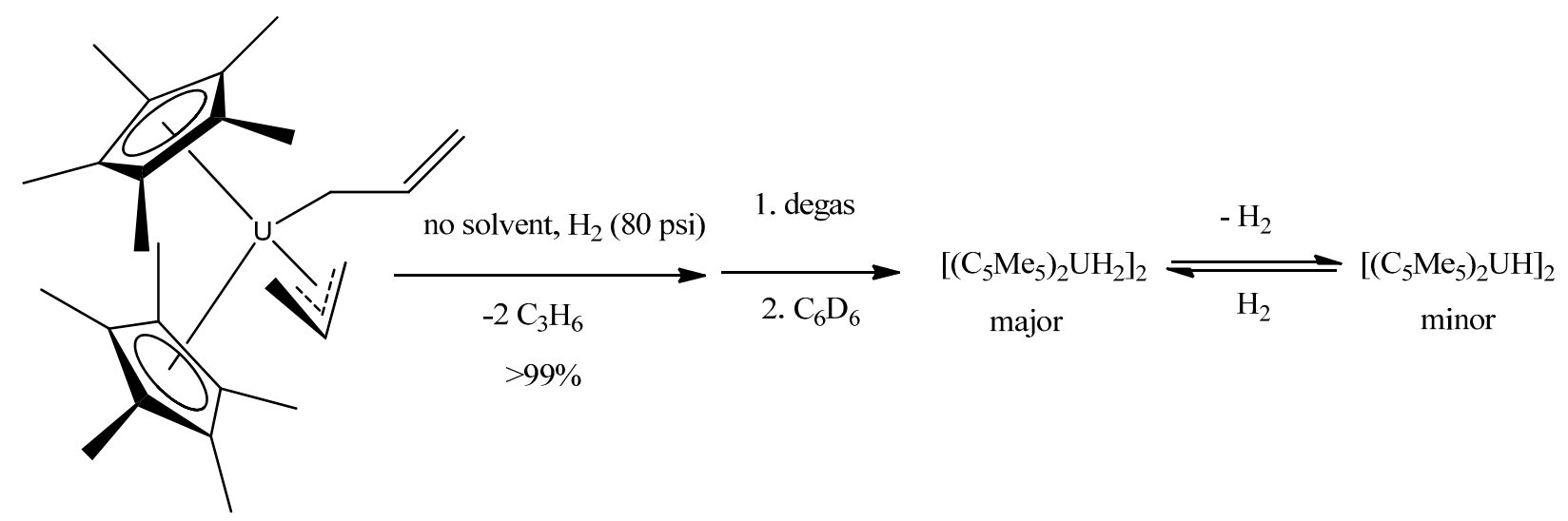

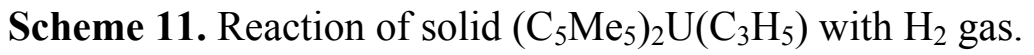
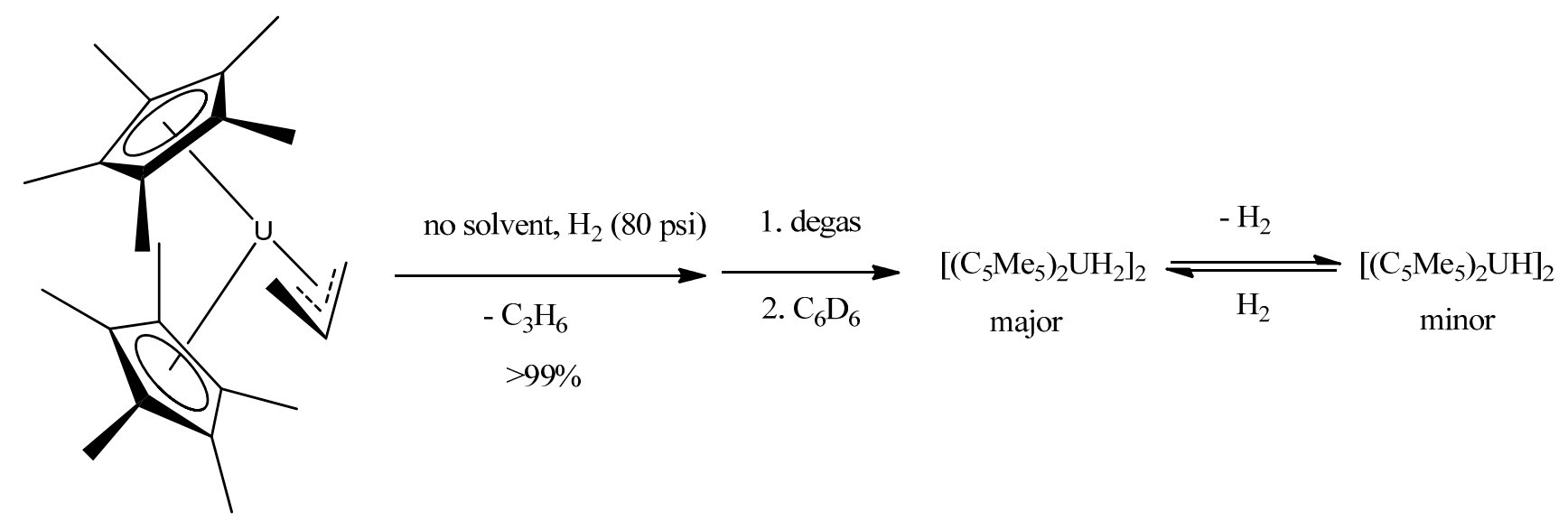

The reaction of $\mathrm{CO}_{2}\left(80\right.$ psi) with solid $\left(\mathrm{C}_{5} \mathrm{Me}_{5}\right)_{2} \mathrm{UMe}_{2}$ forms the monocarboxylate

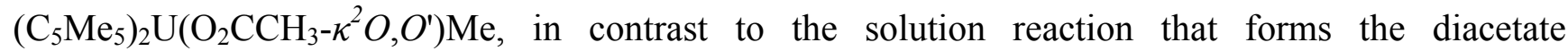
$\left(\mathrm{C}_{5} \mathrm{Me}_{5}\right)_{2} \mathrm{U}\left(\mathrm{O}_{2} \mathrm{CCH}_{3}-\kappa^{2} \mathrm{O}, \mathrm{O}^{\prime}\right)_{2}$ in minutes.

The bipyridyl thorium metallocenes $\left[\eta^{5}-1,2,4-\left(\mathrm{Me}_{3} \mathrm{C}\right)_{3} \mathrm{C}_{5} \mathrm{H}_{2}\right]_{2} \mathrm{Th}($ bipy $)$ and $\left[\eta^{5}-1,3-\right.$ $\left.\left(\mathrm{Me}_{3} \mathrm{C}\right)_{2} \mathrm{C}_{5} \mathrm{H}_{3}\right]_{2} \mathrm{Th}$ (bipy) (see also bipy complexes above) were investigated by magnetic susceptibility and computational studies [73]. It was revealed that these complexes are not diamagnetic, but they behave as temperature independent paramagnets. In addition, they react with $\mathrm{Ph}_{2} \mathrm{CS}$ to give $\left[\eta^{5}-1,2,4-\right.$ $\left.\left(\mathrm{Me}_{3} \mathrm{C}\right)_{3} \mathrm{C}_{5} \mathrm{H}_{2}\right]_{2} \mathrm{Th}\left[(\right.$ bipy $\left.)\left(\mathrm{SCPh}_{2}\right)\right]$ and $\left[\eta^{5}-1,3-\left(\mathrm{Me}_{3} \mathrm{C}\right)_{2} \mathrm{C}_{5} \mathrm{H}_{3}\right]_{2} \mathrm{Th}\left[(\right.$ bipy $\left.)\left(\mathrm{SCPh}_{2}\right)\right]$, respectively, in quantitative conversions. Also, conformationally restricted $\mathrm{Th}^{\mathrm{IV}}$ and $\mathrm{U}^{\mathrm{IV}}$ complexes, [ $\left.\mathrm{ThCl}_{2}(\mathrm{~L})\right]$ and $\left[\mathrm{UI}_{2}(\mathrm{~L})\right]$ (Scheme 12), of the small-cavity, dipyrrolide, dianionic macrocycle transcalix[2]benzene[2]pyrrolide (L) (see also calixarene complexes above) were reported and were shown to have unusual $\mathrm{k}^{5}: \mathrm{k}^{5}$ binding in a bent metallocene-type structure [74].

Reaction of the uranium alkyl complex $\left(\mathrm{C}_{5} \mathrm{Me}_{5}\right)_{2} \mathrm{UMe}_{2}$ (Scheme 13) with $\mathrm{Et}_{3} \mathrm{~N} \cdot 3 \mathrm{HF}$ in toluene in the presence of a donor ligand (pyridine or trimethylphosphine oxide) resulted in gas evolution and the formation of the uranium(IV) difluoride complexes $\left(\mathrm{C}_{5} \mathrm{Me}_{5}\right)_{2} \mathrm{UF}_{2}(\mathrm{~L})\left(\mathrm{L}=\mathrm{NC}_{5} \mathrm{H}_{5}, \mathrm{Me}_{3} \mathrm{P}=\mathrm{O}\right)$ [75]. The fluoride complex $\left(\mathrm{C}_{5} \mathrm{Me}_{5}\right)_{2} \mathrm{UF}_{2}\left(\mathrm{NC}_{5} \mathrm{H}_{5}\right)$ was reactive against several trimethylsilyl compounds, showing that the U-F bond may provide of a new synthetic tool for the preparation of new functional groups, presently not available from alkoxide and chloride complexes. 
Scheme 12. Synthesis of $\left[\mathrm{ThCl}_{2}(\mathrm{~L})\right]$ and $\left[\mathrm{UI}_{2}(\mathrm{~L})\right]$.
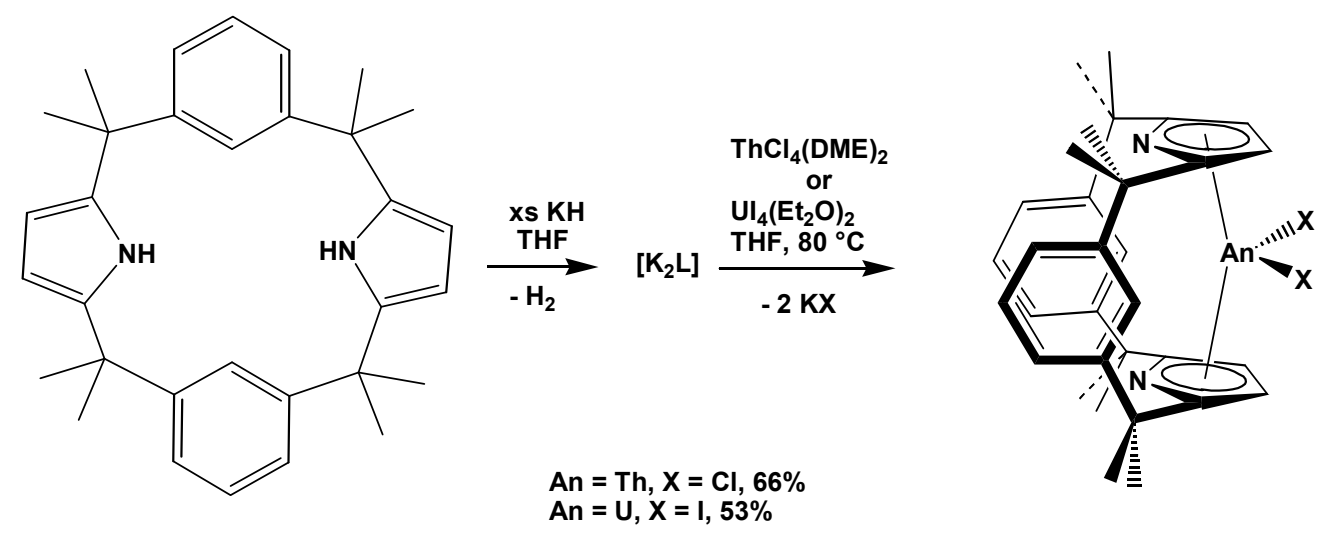

Scheme 13. Formation of uranium(IV) difluoride complexes $\left(\mathrm{C}_{5} \mathrm{Me}_{5}\right)_{2} \mathrm{UF}_{2}(\mathrm{~L})$.
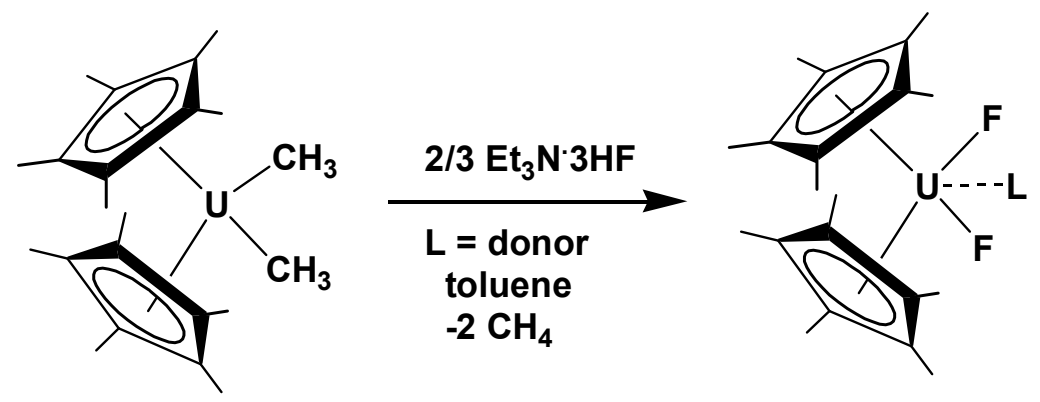

$$
\begin{aligned}
& \mathrm{L}=\mathrm{NC}_{5} \mathrm{H}_{5} \\
& \mathrm{~L}=\mathrm{CH}_{3} \mathrm{P}=\mathrm{O}
\end{aligned}
$$

Recently, a new class of bitopic ligands containing phenantroline and 1,3,5-triazine cores and functionalized with picolinamide groups were prepared. The ligands were able to extract and separate actinides selectively at different oxidation states [76].

\section{Part B. Technetium-99m Chemistry}

\section{B.1. General Concepts on Technetium Complexes}

Technetium (Tc) has no stable isotopes; every form of Tc is radioactive. Due to that, there is not almost any natural Tc present on Earth (with the exception of that produced from the spontaneous fission product in uranium ores) and most of it has to be produced synthetically. It was first discovered in 1937 by Carlo Perrier and Emilio Segrè at the University of Palermo by proving that the radioactivity in a molybdenum foil discarded from a cyclotron at Lawrence Berkeley National Laboratory was produced by an element with $Z=43$. Technetium short-lived metastable nuclide ${ }^{99 \mathrm{~m}} \mathrm{Tc}$ $\left(\mathrm{T}_{1 / 2} 6.015 \mathrm{~h}, \gamma\right.$-irradiator) was later isolated by Segrè and Glean T. Seaborg at Berkeley and it has been widely used until today as a radiotracer in Nuclear Medicine.

In the last 10 years, around 1,000 papers have been published, reporting the preparation and structural characterization of Tc complexes with a wide variety of ligands, or the use of ${ }^{99 \mathrm{~m}} \mathrm{Tc}$ as a radiotracer or radio-emitter in nuclear medicine. Specific applications have been reported in bone scanning, selective imaging of heart, brain, kidney, liver, lungs and other organs, as well as a 
radiolabeling agent for tumor tissues. Due to its low $\gamma$ radiation energy (140 keV), short half-life and accessibility, ${ }^{99 \mathrm{~m}} \mathrm{Tc}$ has been the most obvious choice in diagnostic nuclear medicine. Some relatively recent reviews on the state-of-the-art of Tc based diagnostic imaging agents, radiotracers and radiopharmaceuticals $[77-83]$. The $\left[\mathrm{Tc}(\mathrm{CO})_{3}\right]^{+}$moiety has been widely exploited for the preparation of bioorganometallic compounds for radiopharmacy and the development of in vivo imaging agents [84]. Macrocyclic chelating ligands, such as crown ethers have been also reviewed as they may become useful as radiopharmaceuticals for heart imaging [85].

Radiopharmaceuticals have evolved from simple metal complexes (first generation) with simple ligands, to higher complexity ligands or even ligands derived from biomolecules, mimicking lipophilic and structural properties to increase biocompatibility, biodistribution and tissue recognition specificity. The last two generations have reached clinical application, although chemically are harder targets to achieve (Figure 29) [80].

Figure 29. Evolution of technetium based radiopharmaceuticals.

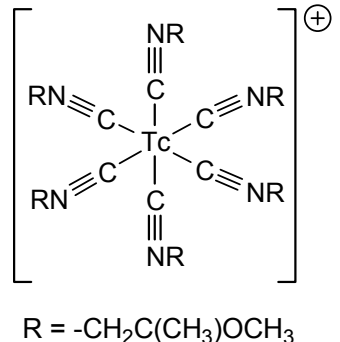

First Generation

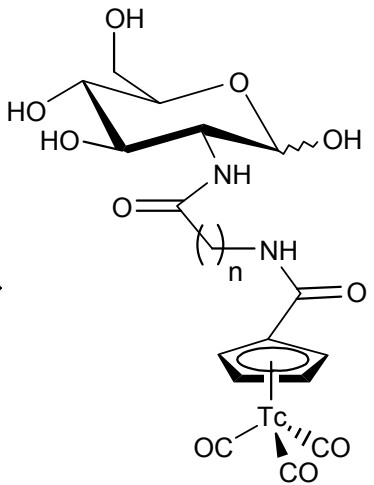

Second Generation
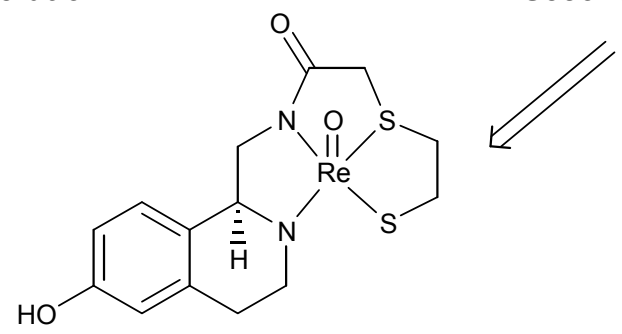

Third Generation

\section{B.2. Technetium Complexes with O-Containing Ligands}

The chemistry of Tc octahedral oxo complexes has been recently reviewed [86]. The synthesis and characterization of neutral complexes $f a c-\left[\mathrm{Tc}(\mathrm{CO})_{3}\left(\mathrm{PR}_{3}\right)((\mathrm{L})]\right.$ and $c i s-\left[\mathrm{Tc}(\mathrm{CO})_{3}\left(\mathrm{PR}_{3}\right)(\mathrm{L})\right]$, with $\mathrm{PR}_{3}=$ triphenylphosphine or methyldiphenylphosphine and $\mathrm{L}=$ acetylacetone or curcumin as the $\mathrm{OO}$ donor ligand, has been reported [87]. Preparation was achieved from the corresponding intermediate aqua complexes $\left[\mathrm{Tc}(\mathrm{CO})_{3}\left(\mathrm{H}_{2} \mathrm{O}\right)(\mathrm{L})\right]$ in the presence of the appropriate tertiary phosphine, which replaced the labile water molecule at room temperature. Under reflux conditions, a second phosphine ligand displace a carbonyl, generating the bisphosphine complex cis-trans- $\left[\mathrm{Tc}(\mathrm{CO})_{2}\left(\mathrm{PR}_{3}\right)_{2}(\mathrm{~L})\right]$ in almost quantitative yield. Selective binding to beta-amyloid plaques for both the monophosphine and 
the bisphosphine complexes of curcumin was reported, making these compounds potentially useful for pharmacological uses.

Antibiotics such as ofloxacin, sitafloxacin, sparafloxacin, norfloxacin, garenoxacin, trovafloxacin, ciprofloxacin and norfloxacin, have been explored as ligands to prepare technetium-99m tricarbonyl complexes (Figure 30). These complexes have been tested against $S$. aureus as a bacterial infection model both in vitro (bacterial cultures) and in vivo (infected rats). All these molecules share a common fluoroquinolone skeleton. Fluoroquinolones are broad-spectrum antibiotics with good oral absorption and excellent bioavailability. They possess a carboxylic acid function at the 3-position and a carbonyl oxygen atom at the 4-position, becoming potentially good bidentate chelating ligands toward metal ions. Preparation of the dithiocarbamate derivative in some cases was explored, in order to use the- $\mathrm{CS}_{2}$ fragment as a coordinating moiety toward the ${ }^{99 \mathrm{~m}} \mathrm{Tc}$ ion. Good biodistribution and high accumulation in the infected region make these complexes suitable for applications as radiotracer for infection imaging [88-96]. Doxycycline, another antibiotic used for the treatment of several infections and part of the tetracycline class, has been also labeled with ${ }^{99 \mathrm{~m}} \mathrm{Tc}$ to explore its use as a radiotracer for infection imaging [97]. It also has several chelating moieties, which makes it a versatile ligand for coordination to metal ions (Figure 31). Stability, sterility and in vivo distribution in an animal model (rats) were performed, finding high uptake in bacterial infection site, yielding promising results.

Figure 30. Antibiotics containing the fluoroquinolone skeleton used to prepare potential infection radiotracer imaging agents: (i) Oxoflacin; (ii) Sitafloxacin; (iii) Sparafloxacin; (iv) Norfloxacin; (v) Garenoxacin; (vi) Trovafloxacin; (vii) Ciprofloxacin. In the box, chelating modes of fluoroquinolones and its dicarbamathe derivatives are shown for sitafloxacin.<smiles>C[C@@H]1COc2c(N3CCN(C)CC3)c(F)cc3c(=O)c(C(=O)O)cn1c23</smiles><smiles>CC1C(F)C1n1cc(C(=O)O)c(=O)c2cc(F)c(N3CC(N)C4(CC4)C3)c(Cl)c21</smiles><smiles>CC1CN(c2c(F)c(N)c3c(=O)c(C(=O)O)cn(C4CC4)c3c2F)CC(C)N1</smiles>

(iv)

(v)<smiles>CCn1cc(C(=O)O)c(=O)c2cc(F)c(N3CCNCC3)cc21</smiles><smiles>C[C@H]1NCc2cc(-c3ccc4c(=O)c(C(=O)O)cn(C5CC5)c4c3OC(F)F)ccc21</smiles><smiles>NC1[C@H]2CN(c3nc4c(cc3F)c(=O)c(C(=O)O)cn4-c3ccc(F)cc3F)C[C@H]12</smiles><smiles>O=C(O)c1cn(C2CC2)c2cc(N3CCNCC3)c(F)cc2c1=O</smiles>

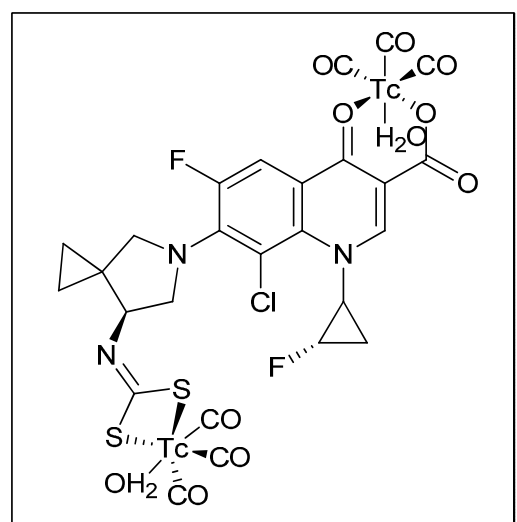


Figure 31. Molecular structure of doxycycline.

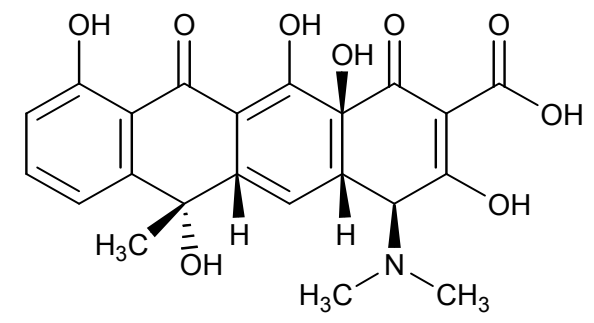

\section{B.3. Technetium Complexes with $\mathrm{N}-, \mathrm{O}-, \mathrm{P}$ - or S-Containing Ligands}

Several technetium coordination complexes with chelating ligands (bi-, tri- and tetradentate) containing at least a nitrogen atom have been reported in the past decade. These ligands seek to overcome problems related to the use of the Tc(I) core as a radiotracer in a metal complex, as they need to be hydrophilic. However, most of the chelating agents are lipophilic, contributing to a poor pharmacokinetic performance. Several of those chelating ligands, coordinate to different ${ }^{99 \mathrm{~m}} \mathrm{Tc}$ targets, such as $\left[\mathrm{Tc}(\mathrm{CO})_{3}\right]^{-}$or $\left[\mathrm{TcO}_{3}\right]^{+}$. For example, the reaction between $\left[\mathrm{TcO}_{4}\right]^{-}$and the strong Lewis acids benzoyl chloride and $\mathrm{BF}_{3} \cdot \mathrm{OEt}_{2}$, was explored for the synthesis of complexes containing the $\left[\mathrm{TcO}_{3}\right]^{-}$core with ligands such as 2,2'-bipyridine, 1,10-phenantroline, di-1H-pyrazol-1-yl acetate, bis(3,5-dimethyl-1H-pyrazol-1-yl)acetate, 1,1,1-methanetriyltris(3,5-dimethyl-1H-pyrazole), and their ${ }^{99}$ Tc NMR spectra recorded; their rhenium analogues were also structurally characterized [98]. Water soluble ${ }^{99 \mathrm{~m}} \mathrm{Tc}$ complexes with sugar-substituted bipyridine complexes obtained from the reaction of 4,4'-dibromomethyl-2,2'-bipyridine with 2,3,4,6-tetra-O-acetyl- $\beta$-D-glucopyranosylthiol, 2,3,4,6-tetraO-acetyl- $\beta$-D-galactopyranosylthiol or 2,3,4,6-tetra-O-acetyl- $\alpha$-D-thioacetylmannopyranoside were obtained and fully characterized (Figure 32).

Figure 32. Example of bidentate ${ }^{99 \mathrm{~m}} \mathrm{Tc}$ complex: a sugar substituted bipyridine Tc-complex.

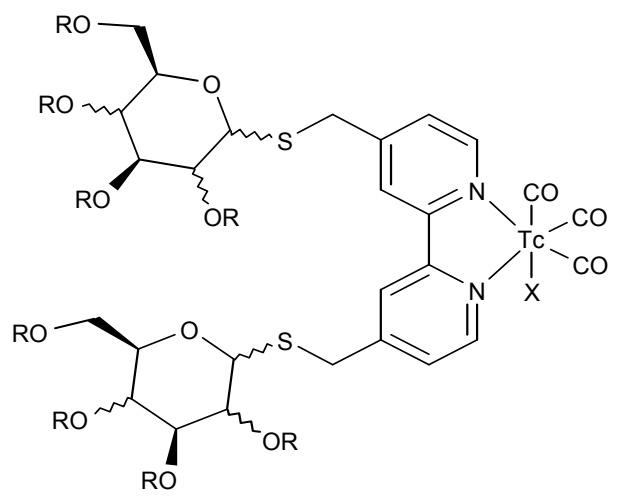

The complexes are stable for several hours in the presence of coordinating ligands (histidine), showing partial ligand-exchange after $24 \mathrm{~h}$ [99]. In other work, the preparation of ${ }^{99 \mathrm{~m}} \mathrm{Tc}$ complex with a bidentate 6-(pyridine-2-methylimine)-4-[3-bromophenyl)amino]-quinazoline ligands was reported recently [100]. This metal complex was explored for use as a biomarker for EGFR positive tumors, observing inhibition of the EGFR autophosphorylation. Finally, a series of myocardial perfusion imaging agents was prepared using different mono- and bidentate ligands (imidazole, 1,10-phenanthroline, 2,2-bipyridine) labeled with tricarbonyl $-{ }^{99 \mathrm{~m}} \mathrm{Tc}$ were reported and fully characterized [101]. 
Dihydropyrimidinone [102] and bemzamidoxime [103] derivatives were synthesized and their ${ }^{99 \mathrm{~m}} \mathrm{Tc}$ complexes prepared using stannous chloride as reducing agent. Their potential uses are as radiotracers for infections (E. coli) or lung radioimaging, showing good biodistribution and stability. The complexes were prepared from sodium pertechnate or ${ }^{99 \mathrm{~m}}$ Tc-glucoheptonate, with high radiochemical yields.

Other ${ }^{99 \mathrm{~m}} \mathrm{Tc}$ complexes with tridentate and tetradentate ligands containing at least a nitrogen donor atom, were prepared, characterized and their use as biomedical radiotracer agents explored. Figures 33 and 34 show the common chelating groups used to tri-coordinate and tetra-coordinate technetium into a complex, respectively. Tables 1 and 2 summarize some selected examples of this type of ${ }^{99 \mathrm{~m}} \mathrm{Tc}$ chelating ligands reported in the lapse time of this review.

Figure 33. Type of chelating group present at the ${ }^{99 \mathrm{~m}} \mathrm{Tc}$ complexes shown in Table 1.

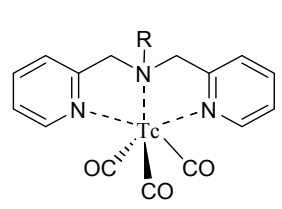

(I)

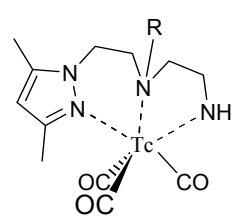

(II)

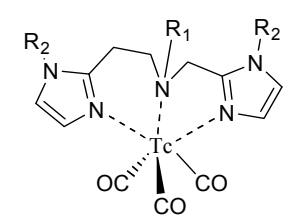

(III)

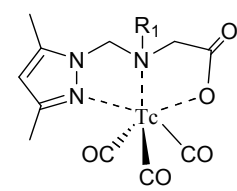

(IV)

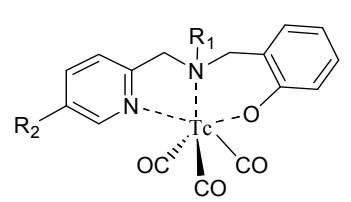

(V)

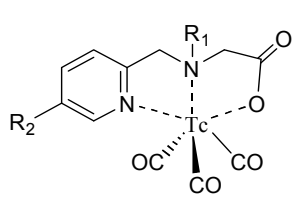

(VI)

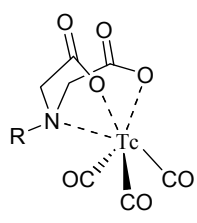

(VII)

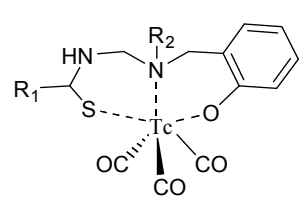

(VIII)

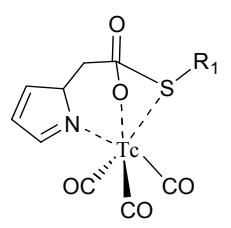

(IX)

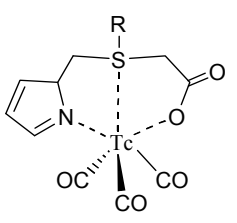

(X)

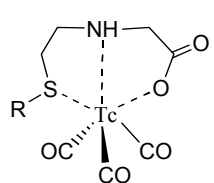

(XI)

Figure 34. Type of chelating group present at the ${ }^{99 \mathrm{~m}} \mathrm{Tc}$ complexes shown in Table 2.

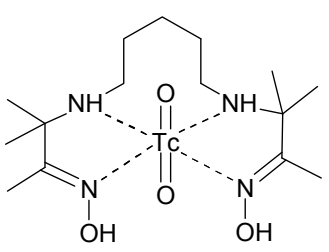

(i)

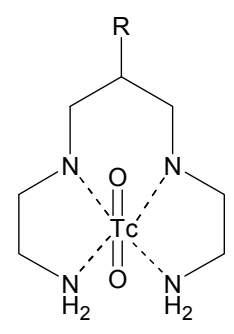

(ii)<smiles>[R]C1N[C@]23O[C@]24SCC([R2])N4CC(=O)N3C1=O</smiles>

(iii)<smiles>[R2]C1CS[C@@]23SCCN2C(=O)CN13</smiles>

(iv)<smiles>[R2]C1CS[C@]23CN1CCN2CCS3</smiles>

(v)<smiles></smiles>

(vi)

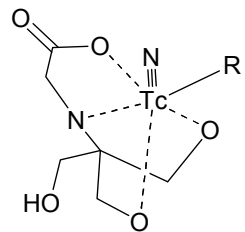

(vii) 
Table 1. Synthesis of ${ }^{99 \mathrm{~m}} \mathrm{Tc}$ complexes with chelating tridentate $\mathrm{N}$ containing ligands.

\begin{tabular}{|c|c|c|c|c|}
\hline $\begin{array}{l}\text { Denticity } \\
\text { and Donor } \\
\text { Atoms } \\
\end{array}$ & Conjugated Ligand & $\begin{array}{l}\text { Chelating } \\
\text { Group }\end{array}$ & Potential Medical Use & Ref. \\
\hline \multirow[t]{17}{*}{$\mathrm{N}, \mathrm{N}, \mathrm{N}$} & Benzothiazole and stilbene & II & Brain imaging & {$[104]$} \\
\hline & Lys-NHCONH-Glu inhibitor & II & $\begin{array}{l}\text { Imaging of prostate specific } \\
\text { membrane antigen (PSMA) }\end{array}$ & {$[105]$} \\
\hline & Cyclo-[Arg-Gly-Asp-D-Tyr-Lys(PZ)] & I & $\begin{array}{l}\text { Integrin receptors in tumor } \\
\text { cells and neovasculature }\end{array}$ & {$[106]$} \\
\hline & $\begin{array}{c}\text { Ala-NLe-cyclo[Asp-His-DPhe-Arg- } \\
\text { Trp-Lys]-NH} \mathrm{NH}_{2}\end{array}$ & I & $\begin{array}{l}\text { Imaging of melanocortin type } \\
1 \text { receptor (MC1R) in } \\
\text { melanoma tumors }\end{array}$ & {$[107]$} \\
\hline & $\begin{array}{l}\text { Lysine aminoacid derivatives } \\
\text { conjugated to octreotide }\end{array}$ & III & Tumor imaging & {$[108]$} \\
\hline & $\begin{array}{c}\text { 16-mer peptide nucleic acid sequence } \\
\text { H-A GAT CAT GCC CGG CAT- } \\
\text { Lys-NH } \mathrm{NH}_{2}\end{array}$ & I & $\begin{array}{l}\text { Radioimaging human } \\
\text { neuroblastoma cells }\end{array}$ & {$[109]$} \\
\hline & $\begin{array}{l}\text { Diethyl phosphonate, phosphoric acid } \\
\text { and bisphosphonic acid derivatives }\end{array}$ & I & Bone imaging & {$[110]$} \\
\hline & L-Arg conjugates & I & $\begin{array}{l}\text { Monitoring of in vivo activity } \\
\text { of inducible nitric oxide } \\
\text { synthase (iNOS) }\end{array}$ & [111] \\
\hline & Lisinopril & II & $\begin{array}{l}\text { Imaging of angiotensin- } \\
\text { convering enzyme (ACE) for } \\
\text { hearth failure monitoring }\end{array}$ & [112] \\
\hline & Insulin & II & $\begin{array}{l}\text { Tracing insulin biochemistry } \\
\text { in vivo }\end{array}$ & {$[113]$} \\
\hline & Aliphatic or aromatic ethers & I, II & Cardiac imaging & {$[114]$} \\
\hline & Glu-urea-Lys, Glu-urea-Glu & I, II & $\begin{array}{l}\text { Imaging of prostate specific } \\
\text { membrane antigen (PSMA) }\end{array}$ & [115] \\
\hline & $\begin{array}{l}\text { DNA intercalator and bomesin } \\
\text { analogue }\end{array}$ & II & $\begin{array}{c}\text { Imaging gastrin releasing } \\
\text { peptide receptor (GRPr) and } \\
\text { Auger therapy }\end{array}$ & {$[116]$} \\
\hline & $\begin{array}{l}\text { Duanidino, N-hydroxyguanidine, N- } \\
\text { methylguanidine, N-nitroguanidine or } \\
\text { S-methylisothiurea moieties }\end{array}$ & II & iNOS visualization & {$[117]$} \\
\hline & Ac-DEVD-R110-D-SAAC-Fmoc & II & Monitoring of apoptosis & {$[118]$} \\
\hline & Pamidronate and alendronate & I & Bone imaging & {$[119]$} \\
\hline & Bile acid & I & $\begin{array}{l}\text { Radiopharmaceuticals for } \\
\text { hepatobiliary diseases, liver } \\
\text { tumor and intestinal cancer }\end{array}$ & {$[120]$} \\
\hline \multirow[t]{5}{*}{$\mathrm{N}, \mathrm{N}, \mathrm{O}$} & Pyridyl-tert-nitrogen-phenol ligand & IV & Radiolabeling agents & {$[121]$} \\
\hline & Glucosamine & IV & $\begin{array}{l}\text { Radiolabeling of glucose } \\
\text { biochemistry }\end{array}$ & {$[122,123]$} \\
\hline & 4-Nitrobenzyl moiety & IV & $\begin{array}{l}\text { Bioreductive diagnostic } \\
\text { radiopharmaceutical }\end{array}$ & {$[124]$} \\
\hline & $\begin{array}{l}\text { 15-[N-(hydroxycarbonylmethyl)-2- } \\
\text { picolylamino)pentadecanoic acid }\end{array}$ & V & $\begin{array}{l}\text { Radiotracer for evaluation of } \\
\text { fatty acid metabolism in } \\
\text { myocardium }\end{array}$ & {$[125]$} \\
\hline & Estradiol & VI & $\begin{array}{l}\text { Imaging agent for estrogen } \\
\text { receptor in tumor cells }\end{array}$ & [126] \\
\hline
\end{tabular}


Table 1. Cont.

\begin{tabular}{|c|c|c|c|c|}
\hline $\begin{array}{l}\text { Denticity } \\
\text { and Donor } \\
\text { Atoms } \\
\end{array}$ & Conjugated Ligand & $\begin{array}{l}\text { Chelating } \\
\text { Group }\end{array}$ & Potential Medical Use & Ref. \\
\hline \multirow{4}{*}{$\mathrm{N}, \mathrm{O}, \mathrm{O}$} & Triphenylphosphine & VI & $\begin{array}{l}\text { Radioactive metalloprobes for } \\
\text { in vivo monitoring of } \\
\text { mitochondira }\end{array}$ & {$[127]$} \\
\hline & Quinazoline derivatives & IV & $\begin{array}{l}\text { Biomarker for EGFR-TK } \\
\text { positive tumors }\end{array}$ & [128] \\
\hline & 2- and 4-Nitroimidazole & VII & Imaging hypoxic cells & [129-131] \\
\hline & $\begin{array}{c}\text { Glucosamino-Asp-cyclic(Arg-Gly- } \\
\text { Asp-D-Phe-Lys) }\end{array}$ & VII & Angiogenesis imaging agent & [132] \\
\hline \multirow[t]{4}{*}{$\mathrm{N}, \mathrm{O}, \mathrm{S}$} & Benzoyl thiourea & VIII & Radiopharmaceuticals & {$[133]$} \\
\hline & Histidine derivatives & IX & Radiopharmaceuticals & {$[134]$} \\
\hline & $\begin{array}{l}\text { 3-(carboxymethylthio)-3-(1H- } \\
\text { imidazol-4-yl)propanoic acid }\end{array}$ & $\mathrm{X}$ & Radiopharmaceuticals & {$[135]$} \\
\hline & Thymidine & XI & $\begin{array}{c}\text { Monitoring activity human } \\
\text { thymidine kinase type } 1\end{array}$ & [136] \\
\hline
\end{tabular}

Table 2. Synthesis of ${ }^{99 \mathrm{~m}} \mathrm{Tc}$ complexes with chelating tetradentate $\mathrm{N}$-containing ligands.

\begin{tabular}{|c|c|c|c|c|}
\hline $\begin{array}{l}\text { Denticity } \\
\text { and Donor } \\
\text { Atoms }\end{array}$ & Conjugated Ligand & $\begin{array}{l}\text { Chelating } \\
\text { Group }\end{array}$ & Potential Medical Use & Ref. \\
\hline \multirow[t]{2}{*}{$\mathrm{N}, \mathrm{N}, \mathrm{N}, \mathrm{N}$} & $\begin{array}{l}\text { 2,2'-(1,4-diaminobutane)b8s(2- } \\
\text { methyl-3-butanone) dioxime }\end{array}$ & $\mathrm{i}$ & Hypoxia markers & {$[137]$} \\
\hline & $\begin{array}{c}\text { 1,4,8,11-tetra-azaundecane } \\
\text { derivatives }\end{array}$ & ii & $\begin{array}{l}\text { SPECT imaging probes for } \\
\text { tumor imaging }\end{array}$ & {$[138]$} \\
\hline \multirow[t]{2}{*}{ N,N,N,S } & 2-nitroimidazole derivative & iii & Tumor hypoxia & [139] \\
\hline & Probestin derivative & iii & $\begin{array}{l}\text { Imaging aminipepetidase } \mathrm{N} \\
(\mathrm{APN}) \text { expression in vivo }\end{array}$ & {$[140]$} \\
\hline \multirow[t]{2}{*}{$\mathrm{N}, \mathrm{N}, \mathrm{S}, \mathrm{S}$} & $\begin{array}{l}\text { Benzothiazole aniline, pyridyl } \\
\text { benzofuran, phenylbenzoxazole, } \\
\text { dibenzylideneacetone derivatives }\end{array}$ & iv, $v$ & $\begin{array}{c}\text { Beta-amyloid plaques imaging } \\
\text { in brain }\end{array}$ & {$[141-144]$} \\
\hline & 2-quinolinecarboxamide & iv & $\begin{array}{l}\text { Peripheral benzodiazepine } \\
\text { receptor (PBR) imaging }\end{array}$ & {$[145]$} \\
\hline \multirow[t]{2}{*}{$\mathrm{N}, \mathrm{S}, \mathrm{S}, \mathrm{S}$} & Fatty acid derivatives & vi & $\begin{array}{c}\text { Myocardial metabolism } \\
\text { imaging }\end{array}$ & {$[146,147]$} \\
\hline & 5-nitroimidazole derivatives & vi & Hypoxia tumor imaging & {$[148]$} \\
\hline $\mathrm{N}, \mathrm{O}, \mathrm{O}, \mathrm{O}$ & Pteroyl-Lys derivative & vii & Tumor imaging & [149] \\
\hline
\end{tabular}

Tridentate complexes, with PNP chelating ligand as shown in Figure 35, have been reported. A couple of works reported the preparation of a lipophilic cationic ${ }^{99 m}$ Tc-DBODC complex (DBODC $=$ dimethoxypropylphosphinoethyl)ethoxyethylamine) which was investigated as myocardial imaging agent [150-152]. The impact of bidentate chelators on lipophilicity, stability and biodistribution in Sprague-Dawley rats of a cationic ${ }^{99 \mathrm{~m}}$ Tc-nitrido complex with a similar PNP 
tridentate ligand was studied; it was found that the metal complex was a very promising candidate for further preclinical studies in other animal models [153]. In a related work, a dithiocarbamate metronidazole derivative, potassium 2-(2-methyl-5-nitro-1H-imidazolyl)ethyldithiocarbamate, was synthesized and its complex with technetium was prepared in order to evaluate its potential as a tumor hypoxia marker [154]. The functionalization of the PNP tridentate ligand with fatty acid ligands was also explored, for being used as labelling agents to follow myocardial metabolism. The fatty acid derivatives were attached to one terminus of the carbon chain into a dithiocarbamate fragment [155].

Figure 35. Schematic representation of the chelating core of PNP tridentate ligands.

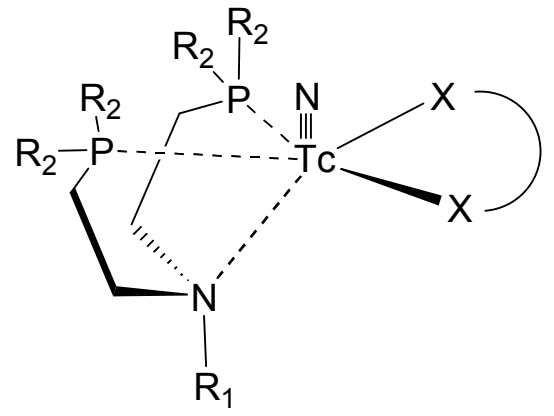

Other metal complexes with different donor atoms were also reported. For example, carboxyl-rich thioether tridentate ligands were used to form technetium complexes and were used to measure effective renal plasma flow in rats. The complexes were formed from the reaction among $\left[\mathrm{Tc}(\mathrm{CO})_{3}\left(\mathrm{H}_{2} \mathrm{O}\right)_{3}\right]^{+}$at $70{ }^{\circ} \mathrm{C}$ and carboxymethylmercaptosuccinic acid or thiodisuccinic acid [156]. A bulky alkylphosphino-thiol bidentate ligand was used to form a complex with technetium; when reacted in the presence of a dithiocarbamate it was found that stable dissymmetrical mixed-substituted complexes were formed [157]. It was reported that these complexes may have potential applications as radiopharmaceuticals for imaging and therapy. Finally, a technetium-diethyl dithiocarbamate (DEDT) complex was prepared by a two-step procedure and studied as a potential brain radiopharmaceutical for brain imaging. Biodistribution in mice indicate that the complex is able to penetrate through the blood-brain-barrier (BBB), suggesting it may be potentially useful as a brain perfusion tracer [158].

From 2007 to the date, several research groups have explored the preparation of Tc(I) complexes based on ligands obtained by click chemistry. Click chemistry provides a useful synthetic tool for the preparation of multifunctional radiopharmaceuticals for several potential biomedical applications. With that in mind, Huisgen click chemistry and monodentate phosphine ligands have been used for biomolecule incorporation on ${ }^{99 \mathrm{~m}} \mathrm{Tc}$ complexes [159]. Bombesin analogues were prepared by a “click approach", using $\mathrm{Cu}(\mathrm{I})$-catalyzed cycloaddition to obtain a new series of triazole-based chelating systems for labeling ${ }^{99 \mathrm{~m}} \mathrm{Tc}(\mathrm{CO})_{3}$ moieties, which presented good biodistribution and improved tumor detection [160,161]. A bidentate ligand containing a bioactive pharmacophore, (2methoxyphenyl)piperazine, has been prepared by this synthetic strategy, to further obtain a lipophilic technetium complex, potentially useful as a CNS imaging agent [162]. In other work, by the same group, the first example of a tridentate ligand obtained by click chemistry, was reported, and it was used to form a ${ }^{99 \mathrm{~m}} \mathrm{Tc}(\mathrm{CO})_{3}$ complex for radioimaging [163]. Finally, a tetradentate ligand able to form 
$\mathrm{Tc}(\mathrm{V})$ complexes was obtained by a "click-to-chelate" strategy, and its ability for being used as a in vivo radiotracer explored successfully [164].

\section{B.4. Technetium Organometallic Complexes}

Technetium organometallic compounds were prepared as potential use for imaging and cancer therapy. A ferrocenyl triarylbutane derivative labeled with ${ }^{99 \mathrm{~m}} \mathrm{Tc}$ by metal exchange reaction with $\left[\mathrm{TcO}_{4}\right]^{-}$was synthesized and its in vivo biodistribution was determined in female Wistar rats, with promising results [165]. Causey and coworkers reported the synthesis and evaluation of mono- and di-aryl technetium metallocarborane derivatives $\left[\left(\mathrm{RR}^{\prime} \mathrm{C}_{2} \mathrm{~B}_{9} \mathrm{H}_{9}\right) \mathrm{Tc}(\mathrm{CO})_{2}(\mathrm{NO})\right]\left(\mathrm{R}=p\right.$ - $\left.\mathrm{PhOH}, \mathrm{R}^{\prime}=\mathrm{H}\right)$ as a new class of probes for estrogen receptors [166]. The technetium-carborane was generated using a cage isomerization process, in high yield (84\%). In a closely related research, a functionalized carborane complex with ${ }^{99 \mathrm{~m}} \mathrm{Tc}$ core, prepared by a microwave assisted approach, was studied for potential use as organometallic probes for in vitro and in vivo correlated imaging [167]. In a different work, long chain fatty acid analogs, labeled with ${ }^{99 \mathrm{~m}} \mathrm{Tc}$ were prepared by linking at the omega-position of pentadecanoic acid acyclopentadienyltricarbonyltechnetium fragment [168]. The novel, lipophilic complex, was injected into rats and it was found to accumulate in myocardial tissue. It is a promising radiotracer for myocardial metabolism monitoring. In 2007, Miroslavov et al. developed a reasonable yield synthesis to prepare $\left[\mathrm{Tc}(\mathrm{CO})_{5} \mathrm{X}\right]\left(\mathrm{X}=\mathrm{Cl}^{-}, \mathrm{Br}^{-}\right)$. From this compound, they were able to prepare the $t$-butyisocyanide and tripheynlphosphine derivatives, by halide substitution [169]. The preparation of a new cytectreene of general formula $\mathrm{RCpTc}(\mathrm{CO})_{3}\left(\mathrm{R}=\mathrm{C}_{6} \mathrm{H}_{5} \mathrm{NHCO}, \mathrm{Cp}=\right.$ cyclopentadyenyl $)$ was prepared from N-phenylferrocenecarboxamide. The ${ }^{99 \mathrm{~m}} \mathrm{Tc}$ complex was lipophilic enough to cross the $\mathrm{BBB}$, making it an interesting base for the development of brain perfusion imaging agents [170]. Finally, in the quest for novel organometallic ${ }^{99 \mathrm{~m}} \mathrm{Tc}$ imaging agents, water stable N-heterocyclic carbine complexes were prepared by the reaction of $\left[\mathrm{TcO}(\mathrm{glyc})_{2}\right]^{-}$(glyc $=$ethyleneglycolato) with 1,3-dimethylimidazoline-2-ylidene, 1,1'-methyelen-3,3'-dimethyl-4,40-dimidazoline-2,2'-diyldene and 1,1'-methylene-3,3'-diethyl-4,4'-diimidazoline-2,20-diyldene in THF. Bidentate NHCs complexes were water-stable over a broad $\mathrm{pH}$ range, paves the way for the design of novel radiopharmaceuticals based on NHC complexes [171]. Figure 36 shows some selected examples of these technetium organometallic compounds.

Figure 36. Selected technetium organometallic compounds.

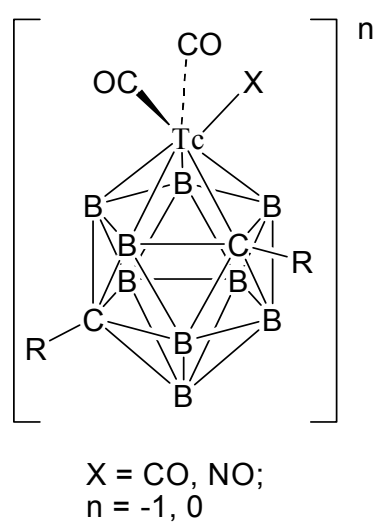

(a)

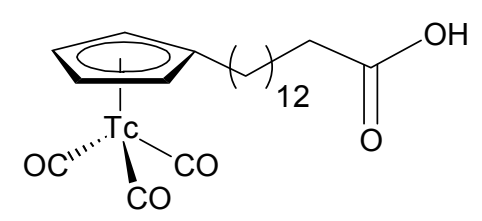

(b)

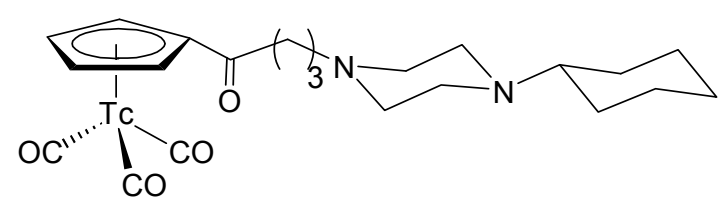

(c) 


\section{B.5. Applications of Technetium Labeling to Nanomaterials}

In the dawn of nanoscience and nanotechnology, radiolabeled nanomaterials are becoming a common practice in the field. Multifunctional nanomaterials can simultaneously be used for diagnostic and therapy in a relatively young field called theranostics [172]. Then, radiotracers incorporated into nanomaterials make them useful as novel medical imaging agents, with the ability to penetrate through several biological barriers, fine tune their selectivity to specific targets and to modulate their biodistribution. This field is still young, but it can be prognosticated that in the future more advances and contributions will be available in the scientific literature. For example, PLA-PEG (polylactic acidpolyethylene oxide) nanocapsules labeled with ${ }^{99 \mathrm{~m}} \mathrm{Tc}-\mathrm{HMPAO}$ (hexamethylpropylene-amine oxime) were prepared and their physical properties (size, size distribution, homogeneity) were determined by photon correlation spectroscopy and zeta potential by laser Doppler anemometry [173]. The results suggest that the radiolabeled nanocapsules were more stable against label leakage in the presence of proteins and could have better performances as radiotracers in vivo. In another work, polylactide-coglycolide (PLGA) nanoparticles containing chloramphenicol were obtained by emulsification solvent evaporation, using polyvinylalcohol (PVA) or polysorbate-80 (PS-80) as surfactants. The nanoparticles were radiolabeled with ${ }^{99 \mathrm{~m}} \mathrm{Tc}$ by stannous reduction and their biodistribution after intravenous administration in mice was followed. Brain uptake was high, with low accumulation in bone marrow. The results are promising for the use of these systems for drug delivery and controlled release agents [174]. The use of technetium as radiolabeling agent to study the biodistribution of self-assembling protein nanoparticles allowed to determine their pharmacokinetic properties in vivo, in order to evaluate their usefulness as vaccine platforms [175]. In another work, pullulan acetate nanoparticles (PAN) were prepared by dialysis and radiolabeled with ${ }^{99 \mathrm{~m}} \mathrm{Tc}$ with a $98 \%$ efficiency. The hydrophobic, spherical particles, with seizes in the range from 50 to $130 \mathrm{~nm}$, were stable in aqueous suspensions and may be efficient for intratumoral administration [176]. Dendrimers belong to a special class of nanostructured materials with growing interest for pharmaceutical and biomedical use. Partially acetylated generation five polyamidoamine (PAMAM) dendrimer (G5-Ac) was reacted with biotin and 2-( $p$ isothiocyanatobenzyl)-6-methyl-diethylenetriamine-pentaacetic acid and avidin to form a dendrimeravidin conjugate, which was radiolabeled with ${ }^{99 \mathrm{~m}} \mathrm{Tc}$. The nanostructured conjugate was evaluated for in vitro cellular uptake and biodistribution [177]. Finally, the preparation, characterization and biodistribution of letrozole loaded PLGA nanoparticles in tumor bearing mice was recently reported [178]. The PLGA nanoparticles were prepared by the solvent evaporation technique and characterized by TEM and DLS; radiolabeling with technetium was achieved with high efficiency and biodistribution indicate that the letrazole loaded nanoparticles present higher tumor uptake than usual drug delivery vehicles.

\section{Conclusions}

During the last 7-10 years (2007-2014), nearly 2,500 research papers have been published containing theoretical and experimental results on the chemistry of actinide and technetium metallic elements. They have revealed novel and interesting physical and chemical properties of their coordination and organometallic chemistry, in particular revealing fundamental information on their 
unusual molecular and electronic structures and reactivity. For instance, the highest observed Werner coordination number (15) has been found in a Th complex with formula $\left[\mathrm{Th}\left(\mathrm{H}_{3} \mathrm{BNMe}_{2} \mathrm{BH}_{3}\right)_{4}\right] \cdot \mathrm{Most}$ of these complexes are formed by chelating, polydentate ligands containg $\mathrm{O}$ - and $\mathrm{N}$-donor centers, but several heteroatom mixed ligands containing S-, P- ligands have been also explored. The solid state structures of these compounds has been extensively studied by single crystal X-ray crystallography in order to determine the variable and unique coordination modes of the several functional groups included into the ligands in order to coordinate toward the radioactive metal atoms. Talking about their usefulness, the design of complex, chelating, multidentate ligands can be applied in the processes of nuclear waste remediation (i.e., recycling of nuclear fuel and the selective separation of actinides and other fission products from waste solutions). Applications in analytical chemistry as specific ligands forrecongnition and determination of actinides in solutions has been also reported. Their rich and unique organometallic chemistry has also been heavily explored, and without any doubt still will keep showing in the future novel compounds with extraordinary properties and structures. Their bioactive properties, resulting from the radioactive and spontaneous emission of alpha or beta particles and/or gamma radiation, have been also explored for the design of novel antimicrobial and anti-fungalcompounds. In particular, the chemistry of technetium- $99 \mathrm{~m}\left({ }^{99 \mathrm{~m}} \mathrm{Tc}\right)$ short-lived metastable nuclide has been exploited for the preparation of metal complexeswith lipophilic ligands for brain and heart radioimaging, asa well as for radiolabeling antibiotics, steroids, peptides and other bioactive molecules, not only for tracking their fate into the organisms, which is of great help for pharmaco-kinetic studies or the understanding of metabolic pathways, but also for the preparation of novel in vivo imaging agents for diagnostics and therapy. A very promising field for the application of ${ }^{99 \mathrm{~m}} \mathrm{Tc}$ or Ac complexes or radiotracers is in the very explosive field of nanoscience and nanotechnology, in particular to the use of nanomaterials in health (nanomedicine). Their application for monitoring the biodistribution, accumulation and metabolism of radiolabeled nanomaterials designed for drug transport and controlled releasing, theranostic agents (simultaneous diagnostics and therapy agents in one material), medical imaging and other related biomedical applications, without any doubt will result in many interesting contributions in the near and far future, which will enrich the already extraordinary broad and productive field of research of radioactive metal complexes.

\section{Acknowledgments}

The authors are deeply thankful to the reviewers for the comments and suggestions made to improve this manuscript.

\section{Author Contributions}

All authors contribute equally to this work. Part A was done by BIK, OVK, UOM and PEM, while Part B was written by MAMR.

\section{Conflicts of Interest}

The authors declare no conflict of interest. 


\section{References}

1. Kirby, H.W.; Morss, L.R. Actinium. In The Chemistry of the Actinide and Transactinide Elements; Springer: Dordrecht, The Netherlands, 2006; Volume 1, pp. 18-51.

2. Stavroula, S.; Kappel, B.J.; Jaggi, J.S.; McDevitt, M.R.; Scheinberg, D.A.; Sgouros, G. Enhanced retention of the $\alpha$-particle emitting daughters of actinium-225 by liposome carriers. Bioconjugate Chem. 2007, 18, 2061-2067.

3. Hudry, D.; Apostolidis, C.; Walter, O.; Griveau, J.-C.; Janssen, A.; Manara, D.; Colineau, E.; Vitova, T.; Wang, D.; Kübel, C.; et al. Ultra small plutonium oxide nanocrystals: Innovative building-blocks in plutonium. Science 2014, submitted.

4. Hudry, D.; Griveau, J.-C.; Apostolidis, C.; Walter, O.; Colineau, E.; Rasmussen, G.; Wang, D.; Chakravadhaluna, V.S.K.; Courtois, E.; Kübel, C.; et al. Thorium/uranium mixed oxide nanocrystals: Synthesis, structural characterization and magnetic properties. Nano Res. 2014, 7 , 119-131.

5. Hudry, D.; Apostolidis, C.; Walter, O.; Gouder, T.; Janssen, A.; Courtois, E.; Kübel, C.; Meyer, D. Synthesis of transuranium-based nanocrystals via the thermal decomposition of actinyl nitrates. RSC Adv. 2013, 3, 18271-18274.

6. Hudry, D.; Apostolidis, C.; Walter, O.; Gouder, T.; Courtois, E.; Kübel, C.; Meyer, D. Controlled synthesis of thorium and uranium oxide nanocrystals. Chem. Eur. J. 2013, 19, 5297-5305.

7. Morss, L.R. Synthetic milestones in $f$ element inorganic chemistry. In Proceedings of the 7th International Conference on f Elements (ICfE-7), Cologne, Germany, 23-27 August 2009; Meyer, G., Ed.; NwT-Verlag: Bornheim, Germany, 2010; Volume 1, pp. 1-6.

8. Fry, C.; Thoennessen, M. Discovery of the actinium, thorium, protactinium, and uranium isotopes. At. Data Nucl. Data Tables 2013, 99, 345-364.

9. Cotton, S.C. Coordination chemistry of the actinides. In Lanthanide and Actinide Chemistry; John Wiley \& Sons, Ltd.: Sussex, UK, 2006.

10. Vlaisavljevich, B.; Mir, P.; Ma, D.; Sigmon, G.E.; Burns, P.C.; Cramer, C.J.; Gagliardi, L. Synthesis and characterization of the first $2 \mathrm{~d}$ neptunyl structure stabilizedby side-on cation-cation interactions. Chem. Eur. J. 2013, 19, 2937-2941.

11. Shiri, S.; Delpisheh, A.; Haeri, A.; Poornajaf, A.; Khezeli, T.; Badkiu, N. Floatationspectrophotometric determination of thorium, using complex formation with eriochrome cyaniner. Anal. Chem. Insights 2011, 6, 1-6.

12. Uhrovcik, J.; Lesny, J. Contribution to validation of spectrophotometric determination ofthorium using Arsenazo III. HEJ: ENV-120131-A. Available online: http://heja.szif.hu/ENV/ENV-120131-A/env120131a.pdf (accessed on 16 July 2014).

13. Jayarami, R.M.; Sudhavani, T.J.; Sivagangi, R. Synergistic extraction of uranium (VI) by complexation with CYANEX-272 and CYANEX-923, TPBD, TNBD, TOPO in presence of nitrate. Int. J. Res. Chem. Environ. 2012, 2, 158-163.

14. Odoh, S.O.; Bylaska, E.J.; de Jong, W.A. Coordination and hydrolysis of plutonium ions in aqueous solution using car-parrinello molecular dynamics free energy simulations. $J$. Phys. Chem. A 2013, 117, 12256-12267. 
15. Vercouter, T.; Vitorge, P.; Amekraz, B.; Giffaut, E.; Hubert, S.; Moulin, C. Stabilities of the Aqueous Complexes $\mathrm{Cm}\left(\mathrm{CO}_{3}\right)_{3}{ }^{3-}$ and $\mathrm{Am}\left(\mathrm{CO}_{3}\right)_{3}{ }^{3-}$ in the Temperature Range $10-70{ }^{\circ} \mathrm{C}$. Inorg. Chem. 2005, 44, 5833-5843.

16. Polinski, M.J.; Wang, S.; Alekseev, E.V.; Depmeier, W.; Liu, G.; Haire, R.G.; Albrecht-schmitt, T.E. Curium(III) borate shows coordination environments of both Plutonium(III) and Americium(III) borates. Angew. Chem. Int. Ed. 2012, 51, 1869-1872.

17. Torapava, N.; Lundberg, D.; Persson, I. A coordination chemistry study of solvated Thorium(IV) ions in two oxygen-donor solvents. Eur. J. Inorg. Chem. 2011, 5273-5278.

18. Rao, L.; Tian, G. Symmetry, optical properties and thermodynamicsof Neptunium(V) complexes. Symmetry 2010, 2, 1-14.

19. Hennig, C.; Takao, S.; Takao, K.; Weiss, S.; Kraus, W.; Emmerling, F.; Meyer, M.; Scheinost, A.C. Identification of hexanuclear Actinide(IV) carboxylates withThorium, Uranium and Neptunium by EXAFS spectroscopy. J. Phys. Conf. Ser. 2013, 430, doi:10.1088/1742-6596/430/1/012116.

20. Thakur, P.; Pathak, P.N.; Gedris, T.; Choppin, G.R. Complexation of Eu(III), Am(III) and $\mathrm{Cm}$ (III) with dicarboxylates: Thermodynamics and structuralaspects of the binary and ternary complexes. J. Solut. Chem. 2009, 38, 265-287.

21. Barkleit, A.; Foerstendorf, H.; Heim, K.; Sachs, S.; Bernhard, G. Complex formation of uranium(vi) with 1-phenylalanine and3-phenylpropionic acid studied by attenuated total reflection. Fourier transform infrared spectroscopy. Appl. Spectrosc. 2008, 62, 798-802.

22. Mendes, M.; Hamadi, S.; le Naour, C.; Roques, J.; Jeanson, A.; Den Auwer, C.; Moisy, P.; Topin, S.; Aupiais, J.; Hennig, C.; et al. Thermodynamical and structural study of protactinium(v) oxalate complexes in solution. Inorg. Chem. 2010, 49, 9962-9971.

23. Müller, M.; Acker, M.; Taut, S.; Bernhard, G. Complex formation of trivalent americium with salicylic acid at very low concentrations. J. Radioanal. Nucl. Chem. 2010, 286, 175-180.

24. Mathur, J.N.; Cernochova, K.; Choppin, G.R. Thermodynamics and laser luminescence spectroscopy of binary and ternary complexation of $\mathrm{Am}^{3+}, \mathrm{Cm}^{3+}$ and $\mathrm{Eu}^{3+}$ with citric acid, and citric acid + EDTA at high ionic strength. Inorg. Chim. Acta 2007, 360, 1785-1791.

25. Fedosseev, A.M.; Grigoriev, M.S.; Budantseva, N.A.; Guillaumont, D.; le Naour, C.; Simoni, E.; den Auwer, C.; Moisy, P. Americium(III) coordination chemistry: An unexplored diversity of structure and bonding. Comptes. Rendus. Chim. 2010, 13, 839-848.

26. King, D.M.; Tuna, F.; McInnes, E.J.L.; McMaster, J.; Lewis, W.; Blake, A.J.; Liddle, S.T. Synthesis and structure of a terminal uranium nitride complex. Science 2012, 337, 717-720.

27. Thomson, R.K.; Cantat, T.; Scott, B.L.; Morris, D.E.; Batista, E.R.; Kiplinger, J.L. Uranium azide photolysis results in $\mathrm{C}-\mathrm{H}$ bondactivation and provides evidence for a terminaluranium nitride. Nat. Chem. 2010, 2, 723-729.

28. Budantseva, N.A.; Grigoriev, M.S.; Fedoseev, A.M. Synthesis, structure, and absorption spectra of complex Neptunium(V) chromate with the guanidinium cation, $\left[\mathrm{C}\left(\mathrm{NH}_{2}\right)_{3}\right]_{3}\left[\mathrm{NpO}_{2}\left(\mathrm{CrO}_{4}\right)_{2}\right]$ $\left(\mathrm{H}_{2} \mathrm{O}\right)$. Russ. J. Coord. Chem. 2013, 39, 360-365.

29. Adam, C.; Kaden, P.; Beele, B.B.; Müllich, U.; Trumm, S.; Geist, A.; Panak, P.J.; Denecke, M.A. Evidence for covalence in a N-donor complex of Americium(III). Dalton Trans. 2013, 42, 14068-14074. 
30. Ölcer, A.; Amayri, S.; Reich, T. Neptunium coordination in room-temperature ionic liquids (BmimCl, BmimMsu and BmimSCN). Available online: http://www.kernchemie.unimainz.de/downloads/JB2011/C07.pdf. (accessed on 16 July 2014).

31. Kraft, S.J.; Fanwick, P.E.; Bart, S.C. Synthesis and characterization of a uranium(iii) complex containing a redox-active 2,2'-bipyridine ligand. Inorg. Chem. 2010, 49, 1103-1110.

32. Takase, M.K.; Fang, M.; Ziller, J.W.; Furche, F.; Evans, W.J. Reduction chemistry of the mixed ligand metallocene $\left[\left(\mathrm{C}_{5} \mathrm{Me}_{5}\right)\left(\mathrm{C}_{8} \mathrm{H}_{8}\right) \mathrm{U}_{2}\left(\eta-\mathrm{C}_{8} \mathrm{H}_{8}\right)\right.$ with bipyridines. Inorg. Chim. Acta 2010, 364, 167-171.

33. Zi, G.; Jia, L.; Werkema, E.L.; Walter, M.D.; Gottfriedsen, J.P.; Andersen, R.A. Preparation and Reactions of Base-Free Bis(1,2,4-tri-tert-butylcyclopentadienyl)uranium Oxide, $\mathrm{Cp}_{2}{ }_{2} \mathrm{UO}$. Organometallics 2005, 24, 4251-4264.

34. Mohammad, A.; Cladis, D.P.; Forrest, W.P.; Fanwick, P.E.; Bart, S.C. Reductive heterocoupling mediated by $\mathrm{Cp}^{*}{ }_{2} \mathrm{U}\left(2,2^{\prime}\right.$-bpy). Chem. Commun. 2012, 48, 1671-1673.

35. Ren, W.; Zi, G.; Walter, M.D. Synthesis, structure, and reactivity of a thorium metallocene containing a 2,2'-bipyridyl ligand. Organometallics 2012, 31, 672-679.

36. Ren, W.; Song, H.; Zi, G.; Walter, M.D. A bipyridyl thorium metallocene: Synthesis, structure and reactivity. Dalton Trans. 2012, 41, 5965-5973.

37. Antunes, M.A.; Pereira, L.C.J.; Santos, I.C.; Mazzanti, M.; Marçalo, J.; Almeida, M. $\left[\mathrm{U}\left(\mathrm{TpMe}_{2}\right)_{2}(\text { bipy) }]^{+}\right.$: A Cationic Uranium(III) complex withsingle-molecule-magnet behavior. Inorg. Chem. 2011, 50, 9915-9917.

38. Hashem, E.; Lorusso, G.; Evangelisti, M.; McCabe, T.; Schulzke, C.; Platts, J.A.; Baker, R.J. Fingerprinting the oxidation state of U(IV) by emission spectroscopy. Dalton Trans. 2013, 42, 14677-14680.

39. Arnold, P.L.; Potter, N.A.; Magnani, N.; Apostolidis, C.; Griveau, J.-C.; Colineau, E.; Morgenstern, A.; Caciuffo, R.; Love, J.B. Synthesis of bimetallic uranium and neptunium complexes of a binucleating macrocycle and determination of the solid-state structure by magnetic analysis. Inorg. Chem. 2010, 49, 5341-5343.

40. Ward, A.L.; Buckley, H.L.; Lukens, W.W.; Arnold, J. Synthesis and characterization of Thorium(IV) and Uranium(IV)corrole complexes. J. Am. Chem. Soc. 2013, 135, 13965-13971.

41. Patkar, S.N.; Burungale, A.S.; Patil, R.J. Separation and liquid-liquid extraction of thorium(IV) as sulfate complex withsynergistic mixture of $\mathrm{N}$ - $n$-octylaniline and trioctylamine as an extractant. Rasayan. J. Chem. 2009, 2, 825-832.

42. Manni, G.L.; Walensky, J.R.; Kraft, S.J.; Forrest, P.; Pérez, L.M.; Hall, M.B.; Gagliardi, L.; Bart, S.C. Computational insights into uranium complexes supported by redox-active $\alpha$-diimine ligands. Inorg. Chem. 2012, 51, 2058-2064.

43. Yin, H.; Lewis, A.J.; Williams, U.J.; Carroll, P.J.; Schelter, E.J. Fluorinated diarylamide complexes of Uranium(III, IV)incorporating ancillary fluorine-to-uranium dative interactions. Chem. Sci. 2013, 4, 798-805.

44. Daly, S.R.; Piccoli, P.M.B.; Schultz, A.J.; Todorova, T.K.; Gagliardi, L.; Gilorami, G.S. Synthesis and properties of a fifteen-coordinate complex: The thorium aminodiboranate [Th( $\left.\left(\mathrm{H}_{3} \mathrm{BNMe}_{2} \mathrm{BH}_{3}\right)_{4}\right]$. Angew. Chem. Int. Ed. 2010, 49, 3379-3381. 
45. Choppin, G.R.; Thakur, P.; Mathur, J.N. Complexation thermodynamics and the structure of the binary and the ternary complexes of $\mathrm{Am}^{3+}, \mathrm{Cm}^{3+}$ and $\mathrm{Eu}^{3+}$ with IDAand EDTA + IDA. Inorg. Chim. Acta 2007, 360, 1859-1869.

46. Marie, C.; Miguirditchian, M.; Guillaumont, D.; Tosseng, A.; Berthon, C.; Guilbaud, P.; Duvail, M.; Bisson, J.; Guillaneux, D.; Pipelier, M.; et al. Complexation of lanthanides(III), Americium(III), and Uranium(VI) with bitopic N,O ligands: An experimental and theoretical study. Inorg. Chem. 2011, 50, 6557-6566.

47. Arnold, P.L.; Turner, Z.R.; Bellabarba, R.M.; Tooze, R.P. Carbon monoxide coupling and functionalisation at a simple uranium coordination complex. Chem. Sci. 2011, 2, 77-79.

48. Gardner, B.M.; Stewart, J.C.; Davis, A.L.; McMaster, J.; Lewis, W.; Blake, A.J.; Liddle, S.T. Homologation and functionalization of carbonmonoxide by a recyclable uranium complex. Proc. Natl. Acad. Sci. USA 2012, 109, 9265-9270.

49. Lapka, J.L.; Paulenova, A.; Zakharov, L.N.; Alyapyshev, M.Y.; Babain, V.A. Coordination of uranium(VI) with $N, N^{\prime}$-diethyl- $N, N^{\prime}$-ditolyldipicolinamide. IOP Conf. Ser.: Mater. Sci. Eng. 2010, 9, doi:10.1088/1757-899X/9/1/012029.

50. Carretta, S.; Amoretti, G.; Santini, P.; Mougel, V.; Mazzanti, M.; Gambarelli, S.; Colineau, E.; Caciuffo, R. Magnetic properties and chiral states of a trimetallic uranium complex. J. Phys. Condens. Matter 2013, doi:10.1088/0953-8984/25/48/486001.

51. Alghool, S.; Abd El-Halim, H.F.; Abd El-sadek, M.S.; Yahia, I.S.; Wahab, L.A. Synthesis, thermal characterization, and antimicrobial activityof lanthanum, cerium, and thorium complexes of amino acidSchiff base ligand. J. Therm. Anal. Calorim. 2013, 112, 671-681.

52. Agnihotri, S.; Arora, K. Physicochemical Investigations of Th(IV) and $\mathrm{UO}_{2}(\mathrm{VI})$ complexes with new schiff basesalong with their toxic effects. Chem. Sci. Trans. 2010, 7, 1045-1054.

53. Yadawe, M.S.; Patil, S.A. Synthesis and spectral characterization of Thorium(IV) complexes with 3-substituted-4-amino-5-mercapto-1,2,4-triazole schiff bases. Glob. J. Sci. Front. Res Chem. 2012, 12, 41-44.

54. Yaul, A.R.; Dhande, V.V.; Aswar, A. Synthesis, characterization, electrical and biological studies of $\mathrm{VO}(\mathrm{IV}), \mathrm{MoO}_{2}(\mathrm{VI}), \mathrm{WO}_{2}(\mathrm{VI})$, Th(IV) and $\mathrm{UO}_{2}(\mathrm{VI})$ complexes with hydrazine ligand. Rev. Roum. Chim. 2010, 55, 537-542.

55. ChandraSekhar Reddy, G.; Devanna, N.; Chandrasekhar, K.B. Sensitive spectrophotometric determination of Thorium(IV) using diacetyl monoxime isonicotinoyl hydrazine (DMIH). Int. J. Appl. Biol. Pharm. Technol. 2011, 2, 133-139.

56. Patil, S.S.; Thakur, G.A.; Shaikh, M.M. Synthesis, characterization and antibacterial studies on some mixed ligand thorium complexes with N- and O-donor ligands. Acta Poloniae. Pharm. Drug Res. 2011, 68, 881-887.

57. Kumar Verma, P. Synthesis, characterization and biocidal studies of rare earth metalcomplexes of diazepam. J. Appl. Chem. 2013, 2, 385-390.

58. Law, G.L.; Andolina, C.M.; Xu, J.; Luu, V.; Rutkowski, P.J.; Muller, G.; Shuh, D.K.; Gibson, J.K.; Raymond, K.N. Circularly polarized luminescence of curium: A new characterization of the $5 f$ actinide complexes. J. Am. Chem. Soc. 2012, 134, 15545-15549. 
59. Andrea, T.; Barnea, E.; Botoshansky, M.; Kapon, M.; Genizi, E.; Goldschmidt, Z.; Eisen, M.S. Synthesis and characterization of new thorium and uraniumphenolate complexes. J. Organomet. Chem. 2007, 692, 1074-1080.

60. Thuéry, P. Molecular and polymeric uranyl and thorium complexeswith sulfonate-containing ligands. Eur. J. Inorg. Chem. 2014, 2014, 58-68.

61. Ramírez, F.M.; Varbanov, S.; Bünzli, J.-C.G.; Scopelliti, R. 5f-Element complexes with a p-tertbutylcalix[4]arene bearing phosphinoyl pendant arms: Separation from rare earths and structural studies. Inorg. Chim. Acta 2011, 378, 163-168.

62. Zhang, Y.; Bhadbhade, M.; Gao, J.; Karatchevtseva, I.; Price, J.R.; Lumpkin, G.R. Synthesis and crystal structures of uranium (VI) and thorium (IV)complexes with picolinamide and malonamide. Inorg. Chem. Commun. 2013, 37, 219-221.

63. Kiegiel, K.; Steczek, L.; Zakrzewska-Trznadel, G. Application of calixarenes as macrocyclic ligands for Uranium(VI): A review. J. Chem. 2013, 2013, 762819.

64. Wu, L.; Fang, Y.Y.; Jia, Y.M.; Yang, Y.Y.; Liao, J.L.; Liu, N.; Yang, X.S.; Feng, W.; Ming, J.L.; Yuan, L.H. Pillar[5] arene-based diglycolamides for highly efficient separation of americium(III) and europium(III). Dalton Trans. 2014, 43, 3835-3838.

65. Tran, Q.H.; Le, V.T.; Nguyen, N.T. Spectroscopy method for determination of Thorium with Azocalix[4]arene. In Proceedings of the 2010 International Conference on Biology, Environment and Chemistry IPCBEE, Hong Kong, China, 28-30 December 2010; Yang Dan, Ed.; IACSIT Press: Singapore, 2011.

66. Crawford, M.-J.; Mayer, P. Synthesis, structural and computational Investigations of $\mathrm{UO}_{2} \mathrm{I}_{4}{ }^{2-}$ : A Structurally characterized U(VI)-I anion. Inorg. Chem. 2005, 44, 5547-5549.

67. Okude, G.; Fujii, T.; Uehara, A.; Sekimoto, S.; Minato, K.; Yamana, H. Unique extraction behavior of americium and curium in a system of TBP and calcium nitrate hydrate melt. IOP Conf. Ser. Mater. Sci. Eng. 2010, doi:10.1088/1757-899X/9/1/012067.

68. Fujii, T.; Okude, G.; Uehara, A.; Yamana, H. Study on coordination characteristics of neptunium anduranium ions in calcium nitrate hydrate melt by Ramanspectrometry and UV/Vis/NIR spectrometry. IOP Conf. Ser. Mater. Sci. Eng. 2010, doi:10.1088/1757-899X/9/1/012061.

69. Sarsfield, M.J.; Sims, J.E.; Taylor, R.J. Extraction of neptunium (IV) ions into 30\% tri-butyl phosphate from nitric acid. Solvent Extr. Ion. Exch. 2009, 27, 638-662.

70. Borts, B.V.; Skoromnaya, S.F.; Tkachenko, V.I. Formation of associates from nanosized complexes of uranium in the water - supercritical carbon dioxide system. J. Kharkiv. Nat. Univ. 2012, 355, 128-134.

71. Vlaisavljevich, B.; Diaconescu, P.L.; Lukens, W.L., Jr.; Gagliardi, L.; Cummins, C.C. Investigations of the electronic structure of arene-bridgeddiuranium complexes. Organometallics 2013, 32, 1341-1352.

72. Webster, C.L.; Ziller, J.W.; Evans, W.J. Solvent-free organometallic reactivity: Synthesis of hydride and carboxylate complexes of uranium and yttrium from gas/solid reactions. Organometallics 2014, 33, 433-436.

73. Ren, W.; Lukens, W.W.; Zi, G.; Maron, L.; Walter, M.D. Is the bipyridyl thorium metallocene a low-valentthorium complex? A combined experimental and computational study. Chem. Sci. 2013, 4, 1168-1174. 
74. Arnold, P.L.; Farnaby, J.H.; White, R.C.; Kaltsoyannis, N.; Gardiner, M.G.; Love, J.B. Switchable $\pi$-coordination and $\mathrm{C}-\mathrm{H}$ metallation insmall-cavity macrocyclic uranium and thorium complexes. Chem. Sci. 2014, 5, 756-765.

75. Thomson, R.K.; Graves, C.R.; Scott, B.L.; Kiplinger, J.L. Organometallic Uranium(IV) fluoride complexes: Preparation usingprotonolysis chemistry and reactivity with trimethylsilyl reagent. Dalton Trans. 2010, 39, 6826-6831.

76. Bisson, J.; Dehaudt, J.; Charbonnel, M.-C.; Guillaneux, D.; Miguirditchian, M.; Marie, C.; Boubals, N.; Dutech, G.; Pipelier, M.; Blot, V.; et al. 1,10-Phenantroline and non-symmetrical 1,3,5-triazine dipicolinamide-based ligands for group actinide extraction. Chem. Eur. J. 2014, 20 , 7819-7829.

77. Benny, P.D.; Moore, A.L. Recent Advances in the Probe Development of Technetium-99m Molecular Imaging Agents. Curr. Org. Synth. 2011, 8, 566-583.

78. Mei, L.; Chu, T. Technetium-99m Radiopharmaceutical Chemistry. Prog. Chem. 2011, 23, 1493-1500.

79. Liu, S.; Chakraborty, S. Tc-99m-centered one-pot synthesis for preparation of Tc-99m radiotracers. Dalton Trans. 2011, 40, 6077-6086.

80. Jurgens, S.; Herrmann, W.A.; Künh, F.E. Rhenium and technetium based radiopharmaceuticals: Developments and recent advances. J. Organomet. Chem. 2014, 751, 83-89.

81. Alberto, R. The particular role of radiopharmacy within bioorganometallic chemistry. J. Organomet. Chem. 2007, 692, 1179-1186.

82. Bowen, M.L.; Orvig, C. 99m-Technetium carbohydrate conjugates as potential agents in molecular imaging. Chem. Commun. 2008, 41, 5077-5091.

83. Mindt, T.; Struthers, H.; Garcia-Garoya, E.; Desbouis, D.; Schibli, R. Strategies for the development of novel tumor targeting technetium and rhenium radiopharmaceuticals. Chimia 2007, 6, 725-731.

84. Morais, M.; Paulo, A.; Gano, L.; Santos, I.; Correia, J.D.G. Target-specific $\mathrm{Tc}(\mathrm{CO})_{3}{ }^{-}$complexes for in vivo imaging. J. Organomet. Chem. 2013, 744, 125-139.

85. Liu, S. Ether and crown ether-containing cationic Tc-99m complexes useful as radiopharmaceuticals for heart imaging. Dalton Trans. 2007, 12, 1183-1193.

86. Sergienko, V.S.; Churakov, A.V. Specific features of technetium mononuclear octahedral oxo complexes: A review. Crystall. Rep. 2013, 58, 1-25.

87. Triantis, C.; Tsotakos, T.; Tsoukalas, C.; Sagnou, M.; Raptopoulou, C.; Terzis, A.; Psycharis, V.; Pelecanou, M.; Pirmettis, I.; Papadopoulos, M. Synthesis and characterization of fac$\left[\mathrm{M}(\mathrm{CO})_{3}(\mathrm{P})(\mathrm{OO})\right]$ and cis-trans- $\left[\mathrm{M}(\mathrm{CO})_{2}(\mathrm{P})\left({ }_{2}\right)(\mathrm{OO})\right]$ complexes $(\mathrm{M}=\mathrm{Re}, \mathrm{Tc}-99 \mathrm{~m})$ with acetylacetone and curcumin as $\mathrm{OO}$ donor bidentate ligands. Inorg. Chem. 2013, 52, 12995-13003.

88. Erfani, M.; Doroudi, A.; Hadisi, L.; Andishmand, A.; Mirshojaei, S.F.; Shafiei, M. Tc-99mtricarbonyl labeling of ofloxacin and its biological evaluation in Staphylococcus aureus as an infection imaging agent. J. Label. Compd. Rad. 2013, 56, 627-631.

89. Qaiser, S.S.; Khan, A.U.; Khan, M.R. Synthesis, biodistribution and evaluation of Tc-99msitafloxacin kit: A novel infection imaging agent. J. Radioanal. Nucl. Chem. 2010, 284, 189-193. 
90. Motaleb, M.A. Preparation, quality control and stability of Tc-99m-sparafloxacin complex, a novel agent for detecting sites of infection. J. Label. Compd. Rad. 2009, 52, 415-418.

91. Ibrahim, I.T.; Motaleb, M.A.; Attalah, K.M. Synthesis and biological distribution of Tc-99mnorfloxacin complex, a novel agent for detecting sites of infection. J. Radioanal. Nucl. Chem. 2010, 285, 431-436.

92. Shah, S.Q.; Khan, A.U.; Khan, M.R. Radiosynthesis and biological evolution of Tc-99m(CO)(3)sitafloxacin dithiocarbamate complex: A promising Staphylococcus aureus infection radiotracer. J. Radioanal. Nucl. Chem. 2011, 288, 131-136.

93. Shah, S.Q.; Khan, A.U.; Khan, M.R. Radiosynthesis and biodistribution of (TcN)-Tc-99mGarenoxacin dithiocarbamate complex a potential infection imaging agent. J. Radioanal. Nucl. Chem. 2011, 288, 56-94.

94. Shah, S.Q.; Khan, M.R. Radiocomplexation and biological characterization of the (TcN)-Tc99m-trovafloxacin dithiocarbamate: A novel methicillin-resistant Staphylococcus aureus infection imaging agent. J. Radioanal. Nucl. Chem. 2011, 288, 215-220.

95. Shah, S.Q.; Khan, A.U.; Khan, M.R. Radiosynthesis and biological evaluation of (TcN)-Tc-99msitafloxacin dithiocarbamate as a potential radiotracer for Staphylococcus aureus infection. J. Radioanal. Nucl. Chem. 2011, 287, 827-832.

96. Kyprianidou, P.; Tsoukalas, C.; Chiotellis, A.; Pagagiannopoulou, D.; Raptopoulou, C.P.; Terzis, A.; Pelecanou, M.; Papadopoulos, M.; Pirmettis, I. First example of well-characterized Re and Tc-99m tricarbonyl complexes of ciprofloxacin and norfloxacin in the development of infection-specific imaging agents. Inorg. Chim. Acta 2011, 370, 236-242.

97. Ïlem-Özdemir, D.; Asikoglu, M.; Ozkilic, H.; Yilmaz, F.; Hosgor-Limoncu, M.; Ayhan, S. Tc-99m-doxycycline hyclate: A new radiolabeled antibiotic for bacterial infection imaging. J. Labelled. Compd. Rad. 2014, 57, 36-41.

98. Tooyama, Y.; Braband, H.; Spingler, B.; Abram, U.; Alberto, R. High-valent technetium complexes with the $\left[\left(\mathrm{TcO}_{3}\right)-\mathrm{Tc}-99\right]^{+}$core from in situ prepared mixed anhydrides of $\left[\left(\mathrm{TcO}_{4}\right)-\mathrm{Tc}-\right.$ 99] and their reactivities. Inorg. Chem. 2008, 47, 257-264.

99. Gottschaldt, M.; Koth, D.; Müller, D.; Klette, I.; Rau, S.; Görfs, H.; Schäfer, B.; Baum, R.P.; Yano, S. Synthesis and structure of novel sugar-substituted bipyridine complexes of rhenium and 99m-technetium. Chem. Eur. J. 2007, 13, 10273-10280.

100. Bourkoula, A.; Paravatou-Petsotas, M.; Papadopoulos, A.; Santos, I.; Pietszch, H.J.; Livaniou, E.; Pelecanou, M.; Papadopoulos, M.; Pirmettis, I. Synthesis and characterization of rhenium and technetium-99m tricarbonyl complexes bearing the 4-[3-bromophenyl]quinazoline moiety as a biomarker for EGFR-TK imaging. Eur. J. Med. Chem. 2009, 44, 4021-4027.

101. Ellis, B.L.; Gorshkov, N.I.; Lumpov, A.A.; Miroslavov, A.E.; Yalfimov, A.N.; Gurzhiy, V.V.; Suglobov, D.N.; Braddock, R.; Adams, J.C.; Smith, A.M.; et al. Synthesis, characterization and pre-clinical evaluation of Tc-99m-tricarbonyl complexes as potential myocardial perfusion imaging agents. J. Labelled. Compd. Rad. 2013, 56, 700-707.

102. De, K.; Chandra, S.; Sarkar, B.; Ganguly, S.; Misra, M. Synthesis and biological evaluation of Tc-99m-DHPM complex: A potential new radiopharmaceutical for lung imaging studies. J. Radioanal. Nucl. Chem. 2010, 283, 621-628. 
103. Thipyapong, K.; Uehara, T.; Tooyama, Y.; Braband, H.; Alberto, R.; Arano, Y. Insight into technetium amidoxime complex: Oxo technetium(v) complex of n-substituted benzamidoxime as new basic structure for molecular imaging. Inorg. Chem. 2011, 50, 992-998.

104. Jia, J.H.; Cui, M.C.; Dai, J.; Wang, X.D.; Ding, Y.S.; Jia, H.; Liu, B. Tc-99m-labeled benzothiazole and stilbene derivatives as imaging agents for A beta plaques in cerebral amyloid angiopathy. MedChemComm 2014, 5, 153-158.

105. Banerjee, S.R.; Foss, C.A.; Castanares, M.; Mease, R.C.; Byun, Y.; Fox, J.J.; Hilton, J.; Lupold, S.E.; Kozikowski, A.P.; Pomper, M.G. Synthesis and evaluation of technetium-99m-and rhenium-labeled inhibitors of the prostate-specific membrane antigen (PSMA). J. Med. Chem. 2008, 51, 4504-4517.

106. Alves, S.; Correia, J.D.G.; Gano, L.; Rold, T.L.; Prasanphanich, A.; Haubner, R.; Rupprich, M.; Alberto, R.; Decristoforo, C.; Santos, I.; et al. In vitro and in vivo evaluation of a novel Tc-99m(CO) $)_{3}$-pyrazolyl conjugate of cyclo-(Arg-Gly-Asp-D-Tyr-Lys). Bioconjugate Chem. 2007, 18, 530-537.

107. Raposinho, P.D.; Xavier, C.; Correia, J.D.G.; Falcao, S.; Gomes, P.; Santos, I. Melanoma targeting with alpha-melanocyte stimulating hormone analogs labeled with fac-[Tc-99m $\left.(\mathrm{CO})_{3}\right]^{+}$: Effect of cyclization on tumor-seeking properties. J. Biol. Inorg. Chem. 2008, 13, 449-459.

108. Maresca, K.P.; Marquis, J.C.; Hillier, S.M.; Lu, G.L.; Femia, F.J.; Zimmerman, C.N.; Eckelman, W.C.; Joyal, J.L.; Babich, J.W. Novel polar single amino acid chelates for technetium-99m tricarbonyl-based radiopharmaceuticals with enhanced renal clearance: Application to octreotide. Bioconjugate Chem. 2010, 21, 1032-1042.

109. Xavier, C.; Giannini, C.; Dall'Angelo, S.; Gano, L.; Maiorana, S.; Alberto, R.; Santos, I. Synthesis, characterization, and evaluation of a novel $(99) \mathrm{mTc}(\mathrm{CO})_{3}$ pyrazolyl conjugate of a peptide nucleic acid sequence. J. Biol. Inorg. Chem. 2008, 13, 1335-1344.

110. Palma, E.; Oliveira, B.L.; Correia, J.D.G.; Gano, L.; Maria, L.; Santos, I.C.; Santos, I. A new bisphosphonate-containing Tc-99m(I) tricarbonyl complex potentially useful as bone-seeking agent: Synthesis and biological evaluation. J. Biol. Inorg. Chem. 2007, 12, 667-679.

111. Oliveira, B.L.; Correia, J.D.G.; Raposinho, P.D.; Santos, I.; Ferreira, A.; Cordeiro, C.; Freire, A.P. Re and Tc-99m organometallic complexes containing pendant L-arginine derivatives as potential probes of inducible nitric oxide synthase. Dalton Trans. 2009, 1, 152-162.

112. Femia, F.J.; Maresca, K.P.; Hillier, S.M.; Zimmerman, C.N.; Joyal, J.L.; Barret, J.A.; Aras, O.; Dilsizian, V.; Eckelman, W.C.; Babich, J.W. Synthesis and evaluation of a series of Tc-99m(CO) ${ }_{3}{ }^{+}$lisinopril complexes for in vivo imaging of angiotensin-converting enzyme expression. J. Nucl. Med. 2008, 49, 970-977.

113. Sundararajan, C.; Besanger, T.R.; Labiris, R.; Guenther, K.J.; Stack, T.; Garafalo, R.; Kawabata, T.T.; Finco-Kent, D.; Zubieta, J.; Babich, J.W.; et al. Synthesis and characterization of rhenium and technetium-99m labeled insulin. J. Med. Chem. 2010, 53, 2612-2621.

114. Maresca, K.P.; Kronauge, J.F.; Zubieta, J.; Babich, J.W. Novel ether-containing ligands as potential (99m)technetium(I) heart agents. Inorg. Chem. Commun. 2007, 10, 1409-1412.

115. Lu, G.L.; Maresca, K.P.; Hillier, S.M.; Zimmerman, C.N.; Eckelman, W.C.; Joyal, J.L.; Babich, J.W. Synthesis and SAR of Tc-99m/Re-labeled small molecule prostate specific 
membrane antigen inhibitors with novel polar chelates. Bioorg. Med. Chem. Lett. 2013, 23, $1557-1563$.

116. Esteves, T.; Marques, F.; Paulo, A.; Rino, J.; Nanda, P.; Smith, C.J.; Santos, I. Nuclear targeting with cell-specific multifunctional tricarbonyl M(I) (M is Re, Tc-99m) complexes: Synthesis, characterization, and cell studies. J. Biol. Inorg. Chem. 2011, 16, 1141-1153.

117. Oliveira, B.L.; Raposinho, P.D.; Mendes, F.; Santos, I.C.; Santos, I.; Ferreira, A.; Cordeiro, C.; Freire, A.P.; Correia, J.D.G. Targeting nitric oxide synthase with Tc-99m/Re-tricarbonyl complexes containing pendant guanidino or isothiourea moieties. J. Organomet. Chem. 2011, 696, 1057-1065.

118. Xiong, C.Y.; Lu, W.; Zhang, R.; Tian, M.; Tong, W.; Gelovani, J.; Li, C. Cell-permeable [Tc$99 \mathrm{~m}(\mathrm{CO})_{3}$ ]-labeled fluorogenic caspase 3 substrate for dual-modality detection of apoptosis. Chem. Eur. J. 2009, 15, 8979-8984.

119. Palma, E.; Correia, J.D.G.; Oliveira, B.L.; Gano, L.; Santos, I.C.; Santos, I. Tc-99m(CO) $3_{3^{-}}$ labeled pamidronate and alendronate for bone imaging. Dalton Trans. 2011, 40, 2787-2796.

120. Huang, L.; Zhu, H.; Xu, X.; Zhang, C.; Shen, Y.-M. Synthesis and characterization of organometallic rhenium(I) and technetium(I) bile acid complexes. J. Organomet. Chem. 2009, 694, 3247-3253.

121. Lim, N.C.; Ewart, C.B.; Bowen, M.L.; Ferreira, C.L.; Barta, C.A.; Adam, M.J.; Orvig, C. Pyridine-tert-nitrogen-phenol ligands: N,N,O-type tripodal chelates for the $\left[\mathrm{M}(\mathrm{CO})_{3}\right]^{+}$core $(\mathrm{M}=\mathrm{Re}, \mathrm{Tc})$. Inorg. Chem. 2008, 47, 1337-1345.

122. Bowen, M.L.; Lim, N.C.; Ewart, C.B.; Misri, R.; Ferreira, C.L.; Hafeli, U.; Adam, M.J.; Orvig, C. Glucosamine conjugates bearing N,N,O-donors: Potential imaging agents utilizing the $\left[\mathrm{M}(\mathrm{CO})_{3}\right]^{+}$core $(\mathrm{M}=\mathrm{Re}, \mathrm{Tc})$. Dalton Trans. 2009, 42, 9216-9227.

123. Bowen, M.L.; Chen, Z.F.; Roos, A.M.; Misri, R.; Ferreira, C.L.; Häfeli, U.; Adam, M.J.; Orvig, C. Long-chain rhenium and technetium glucosamine conjugates. Dalton Trans. 2009, 42, 9228-9236.

124. Giglio, J.; Patsis, G.; Pirmettis, I.; Papadopoulos, M.; Raptopoulou, C.; Pelecanou, M.; Leon, E.; Gonzalez, M.; Cerecetto, H.; Rey, A. Preparation and characterization of technetium and rhenium tricarbonyl complexes bearing the 4-nitrobenzyl moiety as potential bioreductive diagnostic radiopharmaceuticals. In vitro and in vivo studies. Eur. J. Med. Chem. 2008, 43, $741-748$.

125. Lee, B.C.; Kim, D.H.; Lee, J.H.; Sung, H.J.; Choe, Y.S.; Chi, D.Y.; Lee, K.H.; Choi, Y.; Kim, B.-T. Tc-99m(CO) $3-15$-[N-(Acetyloxy)-2-picolylamino]pentadecanoic acid: A potential radiotracer for evaluation of fatty acid metabolism. Bioconjugate Chem. 2007, 18, 1332-1337.

126. Neto, C.; Oliveira, M.C.; Gano, L.; Marques, F.; Thiemann, T.; Santos, I. Novel estradiol based metal complexes of Tc-99m. J. Inorg. Biochem. 2012, 111, 1-9.

127. Moura, C.; Mendes, F.; Gano, L.; Santos, I.; Paulo, A. Mono- and dicationic Re(I)/Tc-99m(I) tricarbonyl complexes for the targeting of energized mitocondria. J. Inorg. Biochem. 2013, 123, 34-45.

128. Fernandes, C.; Santos, I.C.; Santos, I.; Pietzsch, H.J.; Kunstler, J.U.; Kraus, W.; Rey, A.; Margaritis, N.; Bourkoula, A.; Chiotellis, A.; et al. Rhenium and technetium complexes bearing 
quinazoline derivatives: Progress towards a $(99 \mathrm{~m})$ Tc biomarker for EGFR-TK imaging. Dalton Trans. 2008, 24, 3215-3225.

129. Mallia, M.B.; Subramanian, S.; Mathur, A.; Sarma, H.D.; Venkatesh, M.; Banerjee, S. Comparing hypoxia-targeting of $(99) \mathrm{mTc}(\mathrm{CO})_{3}$-labeled 2-nitro 4-nitroimidazole. J. Label. Compd. Rad. 2008, 51, 308-313.

130. Mallia, M.B.; Subramaniana, S.; Mathur, A.; Sarma, H.D.; Venkatesh, M.; Banerjee, S. Synthesis and evaluation of 2-, 4-, 5-substituted nitroimidazole-iminodiacetic acid-Tc-99m(CO) 3 complexes to target hypoxic tumors. J. Label. Compd. Rad. 2010, 53, 535-542.

131. Mallia, M.B.; Subramanian, S.; Mathur, A.; Sarma, H.D.; Venkatesh, M.; Banerjee, S. On the isolation and evaluation of a novel unsubstituted 5-nitroimidazole derivative as an agent to target tumor hypoxia. Bioorg. Med. Chem. Lett. 2008, 18, 5233-5237.

132. Lee, B.C.; Sung, H.J.; Kim, J.S.; Jung, K.H.; Choe, Y.S.; Lee, K.H.; Chi, D.Y. Synthesis of Tc99m labeled glucosamino-Asp-cyclic(Arg-Gly-Asp-D-Phe-Lys) as a potential angiogenesis imaging agent. Bioorg. Med. Chem. Lett. 2007, 15, 7755-7764.

133. Nguyen, H.H.; Deflon, V.M.; Abram, U. Mixed-ligand complexes of technetium and rhenium with tridentate benzamidines and bidentate benzoylthioureas. Eur. J. Inorg. Chem. 2009, 21, 3179-3187.

134. Papagiannopoulou, D.; Tsoukalas, C.; Makris, G.; Raptopoulou, C.P.; Psycharis, V.; Leonidiadis, L.; Gdniazdowska, E.; Kozminski, P.; Fuks, L.; Pelecanou, M.; et al. Histidine derivatives as tridentate chelators for the fac-[M-I $\left.(\mathrm{CO})_{3}\right](\mathrm{Re}, \mathrm{Tc}-99 \mathrm{~m}, \mathrm{Re}-188)$ core: Synthesis, structural characterization, radiochemistry and stability. Inorg. Chim. Acta 2011, 378, 333-337.

135. Papagiannopoulou, D.; Makris, G.; Tsoukalas, C.; Raptopoulou, C.P.; Terzis, A.; Pelecanou, M.; Pirmettis, I.; Papadopoulos, M.S. Rhenium(I) and technetium(I) fac-M(NSO)(CO) 3 ( $\mathrm{M}=\mathrm{Re}$, Tc-99m) tricarbonyl complexes, with a tridentate NSO bifunctional agent: Synthesis, structural characterization, and radiochemistry. Polyhedron 2010, 29, 876-880.

136. Desbouis, D.; Struthers, H.; Spiwok, V.; Küster, T.; Schibli, R. Synthesis, in vitro, and in silico evaluation of organometallic technetium and rhenium thymidine complexes with retained substrate activity toward human thymidine kinase type 1. J. Med. Chem. 2008, 51, 6689-6698.

137. Sun, X.; Chu, T.W.; Wang, X.Y. Preliminary studies of Tc-99m-BnAO and its analogues: Synthesis, radiolabeling and in vitro cell uptake. Nucl. Med. Biol. 2010, 37, 117-123.

138. Abiraj, K.; Mansi, R.; Tamma, M.L.; Forrer, F.; Cescato, R.; Reubi, J.C.; Akyel, K.G.; Maecke, H.R. Tetraamine-derived bifunctional chelators for technetium-99m labelling: Synthesis, Bioconjugation and evaluation as targeted SPECT imaging probes for GRP-receptorpositive tumours. Chem. Eur. J. 2010, 16, 2115-2124.

139. Joyard, Y.; Le Joncur, V.; Castel, H.; Diouf, C.B.; Bischoff, L.; Papamicaël, C.; Levacher, V.; Vera, P.; Bohn, P. Synthesis and biological evaluation of a novel Tc-99m labeled 2-nitroimidazole derivative as a potential agent for imaging tumor hipoxia. Bioorg. Med. Chem. Lett. 2013, 23, 3074-3078.

140. Pathuri, G.; Hedrick, A.F.; Disch, B.C.; Doan, J.T.; Ihnat, M.A.; Awasthi, V.; Gali, H. Synthesis and evaluation of novel Tc-99m labeled probestin conjugates for imaging APN/CD13 expression in vivo. Bioconjugate Chem. 2012, 23, 115-124. 
141. Chen, X.J.; Yu, P.R.; Zhang, L.F.; Liu, B. Synthesis and biological evaluation of Tc-99m, Remonoamine-monoamide conjugated to 2-(4-aminophenyl) benzothiazole as potential probes for beta-amyloid plaques in the brain. Bioorg. Med. Chem. Lett. 2008, 18, 1442-1445.

142. Cheng, Y.; Ono, M.; Kimura, H.; Ueda, M.; Saji, H. Technetium-99m Labeled Pyridyl Benzofuran Derivatives as Single Photon Emission Computed Tomography Imaging Probes for beta-Amyloid Plaques in Alzheimer's Brains. J. Med. Chem. 2012, 55, 2279-2286.

143. Wang, X.; Cui, M.; Yu, P.; Li, Z.; Yang, Y.; Jia, H.; Liu, B. Synthesis and biological evaluation of novel technetium-99m labeled phenylbenzoxazole derivatives as potential imaging probes for beta-amyloid plaques in brain. Bioorg. Med. Chem. Lett. 2012, 22, 4327-4331.

144. Yang, Y.; Cui, M.; Jin, B.; Wang, X.; Li, Z.; Yu, P.; Jia, J.; Fu, H.; Jia, H.; Liu, B. Tc-99m-labeled dibenzylideneacetone derivatives as potential SPECT probes for in vivo imaging of beta-amyloid plaque. Eur. J. Med. Chem. 2013, 64, 90-98.

145. Cappelli, A.; Mancini, A.; Sudati, F.; Valenti, S.; Anzini, M.; Belloi, S.; Moresco, R.M.; Matarrese, M.; Vaghi, M.; Fabro, A.; et al. Synthesis and biological characterization of novel 2quinolinecarboxamide ligands of the peripheral benzodiazepine receptors bearing technetium99m or rhenium. Bioconjugate Chem. 2008, 19, 1143-1153.

146. Walther, M.; Jung, C.M.; Bergmann, R.; Pietzsch, J.; Rode, K.; Fahmy, K.; Mirtschink, P.; Stehr, S.; Heintz, A.; Wunderlich, G.; et al. Synthesis and biological evaluation of a new type of (99m)Technetium-labeled fatty acid for myocardial metabolism imaging. Bioconjugate Chem. 2007, 18, 216-230.

147. Mirschink, P.; Stehr, S.N.; Pietzsch, H.J.; Bergmann, R.; Pietzsch, J.; Wunderlich, G.; Heintz, A.C.; Kropp, J.; Spies, H.; Kraus, W.; Deussen, A.; et al. Modified "4+1" mixed ligand technetium-labeled fatty acids for myocardial imaging: Evaluation of myocardial uptake and biodistribution. Bioconjugate Chem. 2008, 19, 97-108.

148. Giglio, J.; Fernandez, S.; Pietzsch, H.J.; Dematteis, S.; Moreno, M.; Pacheco, J.P.; Cerecetto, H.; Rey, A. Synthesis, in vitro and in vivo characterization of novel Tc-99m-'4+1'-labeled 5-nitroimidazole derivatives as potential agents for imaging hypoxia. Nucl. Med. Biol. 2012, 39, 679-686.

149. Guo, H.; Xie, F.; Zhu, M.; Li, Y.; Yang, Z.; Wang, X.; Lu, J. The synthesis of pteroyl-lys conjugates and its application as Technetium-99m labeled radiotracer for folate receptor-positive tumor targeting. Bioorg. Med. Chem. Lett. 2011, 21, 2025-2029.

150. Bolzati, C.; Carta, D.; Gandin, V.; Marzano, C.; Morellato, N.; Salvarese, N.; Cantore, M.; Colabufo, N.A. Tc-99m(N)-DBODC(5), a potential radiolabeled probe for SPECT of multidrug resistance: In vitro study. J. Biol. Inorg. Chem. 2013, 18, 523-538.

151. Bolzati, C.; Cavazza-Ceccato, M.; Agostini, S.; Tokunaga, S.; Casara, D.; Bandoli, G. Subcellular distribution and metabolism studies of the potential myocardial imaging agent $\left[{ }^{99 \mathrm{~m}} \mathrm{Tc}(\mathrm{N})(\mathrm{DBODC})(\mathrm{PNP} 5)\right]^{+} . J$. Nucl. Med. 2008, 49, 1336-1344.

152. Cittanti, C.; Uccelli, L.; Pasquali, M.; Boschi, A.; Flammia, C.; Bagatin, E.; Casali, M.; Stabin, M.G.; Feggi, L.; Giganti, M.; et al. Whole-body biodistribution and radiation dosimetry of the new cardiac tracer Tc-99m-N-DBODC. J. Nucl. Med. 2008, 49, 1299-1304.

153. Liu, S.; He, Z.J.; Hsieh, W.-Y.; Kim, Y.-S. Impact of bidentate chelators on lipophilicity, stability, and biodistribution characteristics of cationic Tc-99m-nitrido complexes. Bioconjugate Chem. 2007, 18, 929-936. 
154. Kong, D.J.; Lu, J.; Ye, S.Z.; Wang, X.B. Synthesis and biological evaluation of a novel asymmetrical Tc-99m-nitrido complex of metronidazole derivative. J. Label. Compd. Rad. 2007, 50, 1137-1142.

155. Cazzola, E.; Benini, E.; Pasquali, M.; Mirtschink, P.; Walther, M.; Pietzsch, H.J.; Uccelli, L.; Boschi, A.; Bolzati, C.; Duatti, A. Labeling of fatty acid ligands with the strong electrophilic metal fragment $[\mathrm{Tc}-99 \mathrm{~m}(\mathrm{~N})(\mathrm{PNP})]^{2+}(\mathrm{PNP}=$ diphosphane ligand). Bioconjugate Chem. 2008, 19, 450-460.

156. He, H.; Lipowska, M.; Christoforou, A.M.; Marzilli, L.G.; Taylor, A.T. Initial evaluation of new (TC)-T-99m(CO $)_{3}$ renal imaging agents having carboxyl-rich thioether ligands and chemical characterization of $\operatorname{Re}(\mathrm{CO})_{3}$ analogues. Nucl. Med. Biol. 2007, 34, 709-716.

157. Bolzati, C.; Cavazza-Ceccato, M.; Agostini, S.; Tisato, F.; Bandoli, G. Technetium and rhenium in five-coordinate symmetrical and dissymmetrical nitrido complexes with alkyl phosphino-thiol ligands. Synthesis and structural characterization. Inorg. Chem. 2008, 47, 11972-11983.

158. Zhang, J.; Wang, X.; Jin, C. Synthesis and biodistribution of the ${ }^{99 \mathrm{~m}} \mathrm{Tc}(\mathrm{CO})_{3}$-DEDT complex as a potential new radiopharmaceutical for brain imaging. J. Radioanal. Nucl. Chem. 2007, 272, 91-94.

159. Hayes, T.R.; Kasten, B.B.; Barnes, C.L.; Benny, P.D. Rhenium and technetium bi- and tricarbonyl complexes in a new strategy for biomolecule incorporation using click chemistry. Dalton Trans. 2014, 43, 6998-7001.

160. Brans, L.; García-Garayoa, E.; Schweinsberg, C.; Maes, V.; Struthers, H.; Schibli, R.; Tourwé, D. Synthesis and evaluation of bombesin analogues conjugataed to two different triazolyl-derived chelators for ${ }^{99 \mathrm{~m}}$ Tc labeling. Chem. Med. Chem. 2010, 5, 1717-1725.

161. Mindt, T.L.; Struthers, H.; Spingler, B.; Brans, L.; Tourwé, D.; García-Garayoa, E.; Schibli, R. Molecular assembly of multifunctional ${ }^{99 \mathrm{~m}} \mathrm{Tc}$ radiopharmaceuticals using "clickable" amino acid derivatives. Chem. Med. Chem. 2010, 5, 2026-2038.

162. Seridi, A.; Wolff, M.; Boulay, A.; Saffon, N.; Coulais, Y.; Picard, C.; Machura, B.; Benoist, E. Rhenium(I) and technetium(I) complexes of a novel pyridyltriazole-based ligand containing an arylpiperazine pharmacophore: Synthesis, crystal structures, computational studies and radiochemistry. Inorg. Chem. Commun. 2011, 14, 238-242.

163. Guizani, S.; Saied, N.M.; Picard, C.; Benoist, E.; Saidi, M. Synthesis and preliminary biological evaluation of the first $99 \mathrm{mTc}(\mathrm{I})$-specific semi-rigid tridentate ligand based on a click chemistry strategy. J. Label. Compd. Radiopharm. 2014, 57, 158-163.

164. Martinage, O.; le Clainche, L.; Czarny, B.; Dugave, C. Synthesis and biological evaluation of a new triazole-oxotechnetium complex. Org. Biomol. Chem. 2012, 10, 6484-6490.

165. Dallagi, T.; Saidi, M.; Vessieres, A.; Huché, M.; Jaouen, G.; Top, S. Synthesis and antiproliferative evaluation of ferrocenyl and cymantrenyl triaryl butene on breast cancer cells. Biodistribution study of the corresponding technetium-99m tamoxifen conjugate. J. Organomet. Chem. 2013, 734, 69-77.

166. Causey, P.W.; Besanger, T.R.; Valliant, J.F. Synthesis and screening of mono- and di-aryl technetium and rhenium metallocarboranes. A new class of probes for the estrogen receptor. J. Med. Chem. 2008, 51, 2833-2844. 
167. Armstrong, A.F.; Lebert, J.M.; Brennan, J.D.; Valliant, J.F. Functionalized carborane complexes of the $\left[\mathrm{M}(\mathrm{CO})_{2}(\mathrm{NO})\right]^{2+}$ core $(\mathrm{M}=\mathrm{Tc}-99 \mathrm{~m}, \mathrm{Re})$ : A new class of Organometallic probes for correlated in vitro and in vivo imaging. Organometallics 2009, 28, 2986-2992.

168. Uehara, T.; Uemura, T.; Hirabayashi, S.; Adachi, S.; Odaka, K.; Akizawa, H.; Magata, Y.; Irie, T.; Arano, Y. Technetium-99m-labeled long chain fatty acid analogues metabolized by beta-oxidation in the heart. J. Med. Chem. 2007, 50, 543-549.

169. Miroslavov, A.E.; Lumpov, A.A.; Sidorenko, G.V.; Levitskaya, E.M.; Gorshkov, N.I.; Suglobov, D.N.; Alberto, R.; Braband, H.; Gurzhiy, V.V.; Krivovichev, S.V.; et al. Complexes of technetium(I) (Tc-99, Tc-99m) pentacarbonyl core with pi-acceptor ligands (tert-butyl isocyanide and triphenylphosphine): Crystal structures of $\left[\mathrm{Tc}(\mathrm{CO})_{5}\left(\mathrm{PPh}_{3}\right)\right] \mathrm{OTf}$ and $\left[\mathrm{Tc}(\mathrm{CO})_{5}\left(\mathrm{CNC}\left(\mathrm{CH}_{3}\right)_{3}\right)\right] \mathrm{ClO}_{4}$. J. Organomet. Chem. 2008, 693, 4-10.

170. Malek-Saied, N.; El Aissi, R.; Ladeira, S.; Benoist, E. Synthesis and biological evaluation of a novel Tc-99m-cyclopentadienyltricarbonyl technetiumcomplex as a new potential brain perfusion imaging agent. Appl. Organomet. Chem. 2011, 25, 680-686.

171. Benz, M.; Spingler, B.; Alberto, R.; Braband, H. Toward organometallic tc-99m imaging Agents: Synthesis of water-stable Tc-99-Nhc complexes. J. Am. Chem. Soc. 2013, 135, 17566-17572.

172. Morales-Avila, E.; Ferro-Flores, G.; Ocampo-García, B.E.; Ramírez, F.M. Radiolabeled nanoparticles for molecular imaging. Mol. Imaging 2012, doi:10.5772/31109.

173. Pereira, M.A.; Mosqueira, V.C.; Vilela, J.M.C.; Andrade, M.S.; Ramaldes, G.A.; Cardoso, V.N. PLA-PEG nanocapsules radiolabeled with $(99 \mathrm{~m})$ Technetium-HMPAO: Release properties and physicochemical characterization by atomic force microscopy and photon correlation spectroscopy. Eur. J. Pharm. Sci. 2008, 33, 42-51.

174. Halder, K.K.; Mandal, B.; Debnath, M.C.; Bera, H.; Ghosh, L.K.; Gupta, B.K. Chloramphenicolincorporated poly lactide-co-glycolide (PLGA) nanoparticles: Formulation, characterization, technetium-99m labeling and biodistribution studies. J. Drug Targ. 2008, 16, 311-320.

175. Yang, Y.; Neef, T.; Mittelholzer, C.; Garayoa, E.G.; Blaunstein, P.; Schibli, R.; Aebi, U.; Burkhard, P. The biodistribution of self-assembling protein nanoparticles shows they are promising vaccine platforms. J. Nanobiotech. 2013, doi:10.1186/1477-3155-11-36.

176. Park, K.H.; Song, H.C.; Na, K.; Born, H.S.; Lee, K.H.; Kim, S.; Kang, D.; Lee, D.H. Ionic strength-sensitive pullulan acetate nanoparticles (PAN) for intratumoral administration of radioisotope: Ionic strength-dependent aggregation behavior and $(99 \mathrm{~m})$ Technetium retention property. Colloids Surf. B 2007, 59, 16-23.

177. Xu, X.P.; Zhang, Y.Q.; Wang, X.D.; Guo, X.X.; Zhang, X.Z.; Qi, Y.J.; Shen, Y.M. Radiosynthesis, biodistribution and micro-SPECT imaging study of dendrimer-avidin conjugate. Bioorg. Med. Chem. 2011, 19, 1643-1648.

178. Mondal, N.; Halder, K.K.; Kamila, M.M.; Debnath, M.C.; Pal, T.K.; Ghosal, S.K.; Sarkar, B.R.; Ganguly, S. Preparation, characterization, and biodistribution of letrozole loaded PLGA nanoparticles in Ehrlich Ascites tumor bearing mice. Int. J. Pharm. 2010, 397, 194-200.

(C) 2014 by the authors; licensee MDPI, Basel, Switzerland. This article is an open access article distributed under the terms and conditions of the Creative Commons Attribution license (http://creativecommons.org/licenses/by/3.0/). 